Received 00th January 20xx, Accepted 00th January 20xx DOI: $10.1039 / x 0 \times x 00000 x$

\title{
Subcritical Water and Supercritical Carbone Dioxide: Efficient and Selective Eco-Compatible Solvents for Coffee and Coffee By-products Valorization
}

\author{
Alexandre Vandeponseele, + Micheline Draye,+ Christine Piot+ and Gregory Chatel+*
}

\begin{abstract}
This review aims to establish the state of the art of the existing literature on the valorization of coffee and coffee by-products (i.e. green coffee, coffee husk, pulp, silverskin and spent coffee grounds) through the use of pressurized fluids as solvents, including subcritical water (SCW) and supercritical carbon dioxide $\left(\mathrm{SC}-\mathrm{CO}_{2}\right)$. The first part reviews the exploitation, the composition, the properties and the ways of valorization of coffee beans and their by-products, highlighting their high potential as raw material. The second part is dedicated to subcritical $\mathrm{H}_{2} \mathrm{O}$ and supercritical $\mathrm{CO}_{2}$ applied to coffee and coffee by-products valorization, discussing the involved mechanisms, the parameters influence and the superiority of subcritical $\mathrm{H}_{2} \mathrm{O}$ and supercritical $\mathrm{CO}_{2}$ in comparison to other solvents and techniques. Indeed, subcritical $\mathrm{H}_{2} \mathrm{O}$ is considered as a super solvent, catalyst and reagent at the same time, being the most efficient technology for carbohydrates and polyphenols recovery as well as biocrude-oil production. Supercritical $\mathrm{CO}_{2}$ is considered as a chameleon solvent, with unlimited tunability, able to selectively extract high value molecules but also compete with organic solvents in amount and quality of the produced extract. In addition, subcritical $\mathrm{H}_{2} \mathrm{O}$ and supercritical $\mathrm{CO}_{2}$ are complementary solvents, targeting together all the types of molecules in coffee and coffee by-products, leading to the development of a Green Solvent Bio-Refinery (GreSBiR) with sequential uses of subcritical $\mathrm{H}_{2} \mathrm{O}$ and supercritical $\mathrm{CO}_{2}$, proposed for the first time in this review.
\end{abstract}

\section{Table of contents}

1. Introduction

2. Coffee

2.1. Coffee exploitation

2.2. Coffee treatments and composition

2.3. Valorization of coffee and coffee by-products

2.4. Characterization of coffee and coffee by-products extracts

2.4.1. Carbohydrates extracts

2.4.2. Antioxidant extracts

2.4.3. Biocrude oil and biochar

2.4.4. Lipid extracts

3. Pressurized fluids applied to coffee and coffee by-products 3.1. Subcritical $\mathrm{H}_{2} \mathrm{O}$ (SCW)

3.1.1. Carbohydrate valorization

3.1.2. Polyphenols valorization:

3.1.2.1. Extraction of the main polyphenols

3.1.2.2. Extraction of secondary antioxidant metabolites

3.1.2.3. Use of non-conventional methods and solvents

3.2. Supercritical $\mathrm{CO}_{2}\left(\mathrm{SC}_{-}-\mathrm{CO}_{2}\right)$

3.2.1. Yield of extraction

3.2.2. Fatty Acid Content (FAC) and triglycerides content

3.2.3. Bioactive molecules

3.2.3.1.Terpenoids

3.2.3.2. Sterols and tocopherols

\subsubsection{Caffeine}

3.2.3.4. Polyphenols

3.2.4. Fractionation

3.3.Major trends, comparison and sequential combination of SCW and $\mathrm{SC}-\mathrm{CO}_{2}$ applied to coffee and coffee by-products valorization

4. Conclusions and perspectives

\section{List of Abbreviations}

$\mathrm{AAE}=$ Ascorbic Acid Equivalent

AbsYield $=$ Absolute Yield

ABTS = 2,2'-azino-bis(3-ethylbenzothiazoline-6-sulfonic acid)

$\mathrm{AOC}=$ AntiOxydant Capacity

$\mathrm{AV}=$ Acid Value

C16:0 $=$ Palmitic Acid

C18:2 = Linoleic Acid

$\mathrm{C}-3-\mathrm{R}=$ Cyanidin-3-Rutinoside

$\mathrm{CAF}=$ Caffeine

$\mathrm{CE}=$ Catechin Equivalent

CGA $=$ ChloroGenic Acids

$\mathrm{CH}=$ Coffee Husk

$\mathrm{CP}=$ Coffee Pulp

CQA = CaffeoylQuinic Acid

$\mathrm{CS}=$ Corn Starch

CSS $=$ Coffee SilverSkin

DAG $=$ DiAcylGlycerol (= DiGlyceride) 
DES = Deep Eutectic Solvent

$\mathrm{DM}=$ Dry Matter

DMC $=$ DiMethyl Carbonate

DPPH $=$ 2,2-diphenyl-1-picrylhydrazyl

$\mathrm{EC} 50=$ Half Effective Concentration

FAC $=$ Fatty Acids Composition

FAME = Fatty Acid Methyl Ester

FFA $=$ Free Fatty Acids

FRAP $=$ Ferric ion Reducing Antioxidant Power

FT-IR = Fourier Transform - InfraRed spectroscopy

$\mathrm{GAE}=$ Gallic Acid Equivalent

GAS = Gaseous AntiSolvent

$\mathrm{GC}=$ Gas Chromatography

$\mathrm{GCB}=$ Green Coffee Bean

$\mathrm{GLU}=\mathrm{Glucose}$ equivalent

GPC $=$ Gel Permeation Chromatography

GReSBiR = Green Solvent Bio-Refinery

$\mathrm{HHV}=$ Higher Heating Value

$\mathrm{HMF}=$ HydroxyMethylFurfural

HPLC = High Performance Liquid Chromatography

$\mathrm{HTC}=$ HydroThermal Carbonization

$\mathrm{HTL}=$ HydroThermal Liquefaction

$\mathrm{IC}_{50}=$ Inhibition Concentration

IPA = IsoPropyl Alcohol

IV = lodine Value

LCA = Life Cycle Assessment

$\mathrm{MAE}=$ MicroWave Assisted Extraction

$\mathrm{MB}=$ Methylene Blue

$\mathrm{MIC}=$ Minimum Inhibitory Concentration

MRPS = Maillard Reaction ProductS

MS = Mass Spectrometer

$\mathrm{MW}=$ MicroWave

NMR = Nuclear Magnetic Resonance

ORAC = Oxygen Radical Absorbance Capacity

OSI = Oxidative Stability Index

PHA = PolyHydroxyAlkanoate

$\mathrm{PV}=$ Peroxide Value

$\mathrm{QE}=$ Quercetin Equivalent

RelYield $=$ Relative Yield

RESS = Rapid Expansion of Supercritical Solution

ROS $=$ Reactive Oxygen Species

$\mathrm{RSs}=$ Reducing Sugars

$\mathrm{SC}-\mathrm{CO}_{2}=$ Supercritical carbon dioxide

SCG $=$ Spent coffee grounds Grounds

SEM = Scanning Electron Microscopy

SCW $=$ SubCritical Water

TAA $=$ Total Antioxydant Activity

TAG $=$ TriAcylGlycerol (= TriGlyceride)

TBARS = Thiobarbituric Acid Reactive Substances

TEAC $=$ Trolox Equivalent Antioxidant Capacity

TFC $=$ Total Flavonoid Content

TGA = ThermoGravimetric Analysis

TPC $=$ Total Polyphenol Content

TSC $=$ Total Sugar Content

$\mathrm{UAE}=$ Ultrasound Assisted Extraction

UPLC = Ultra Performance Liquid Chromatography

US = UltraSound
$\mathrm{XRD}=\mathrm{X}$-Ray Diffraction

\section{Introduction}

Bioeconomy is one of the most popular concepts of the $X X I^{\text {th }}$ century. It is defined as the production of chemicals, materials and/or energy from bio-resources, and the valorization of their by-products and waste. In this context, agricultural, forestry, aquatic or agrifood waste can be used rather than raw materials used to produce food. Agricultural by-products can be used to generate biohydrogen by fermentation processes for energy production ${ }^{1}$ or biopolymers such as polyhydroxyalcanoate (PHA) for materials preparation. ${ }^{2}$ Wheat waste can be employed to produce succinic acid, a platform molecule. Olive mill waste is a source of high value polyphenols such as hydroxytyrosol, a phenolic phytochemical with antioxidant properties. $^{3}$ Viticultural waste such as grape canes and stocks contains resveratrol and $\varepsilon$-viniferin, two powerful antioxidants. ${ }^{4}$ Needles form pine tree waste are rich in proanthocyanidins, which are a class of polyphenols. ${ }^{5}$ Invasive plants such as Fallopia japonica or Fallopia sachalinensis can be also valorized by extraction of the antioxidant extracts rich in triterpenoids and polyphenols they contain. ${ }^{6}$ Aquatic waste such as microalgae have been studied for the production of biodiesel and glycerol as subproduct. ${ }^{7}$ Moreover, other microalgae are rich in astaxanthine, terpenoid, and protein that are valuable compounds. ${ }^{8}$ Indeed, many examples have reported the successful recovery of different biomolecules from agrifood waste, with high potential in pharmaceutical, nutraceutical and/or cosmetic fields. ${ }^{9}$ In the same way, coffee and their byproducts (i.e., coffee pulp, husks, silverskins and spent coffee grounds) have been also widely studied these last years. ${ }^{10}$

Green chemistry aims to design of chemical products and processes that are more environmentally benign, and that present reduced negative impacts to human health and environment. ${ }^{11}$ Thus, the choice of coffee and its by-products as renewable feedstocks rather than petrosourced ones is in accordance with the seventh principle of green chemistry. ${ }^{11}$

Many extraction processes are based on the use of organic solvents, which may have certain drawbacks such as their use in large volumes, obtaining poor extraction selectivities and the generation of large amount of undesirable waste, making then the process expensive. ${ }^{12}$ Moreover, organic solvent are hazardous for the operators in laboratories and industries due to their potential flammability, explosiveness, corrosivity and carcinogenic, mutagenic or reprotoxic properties. ${ }^{13}$

Hence, a myriad of new technologies and solvents have been developed to perform extraction more respectful for the environment. These include extractions assisted by nonconventional methods of activation such as ultrasound (US), 14, 15,16 microwaves (MW), 6, 17,18, pulse electric field $(\mathrm{PEF})^{19}$ or high voltage electric discharge (HVED). ${ }^{20}$ Those methods are of great interest to increase extraction yields, reducing extraction times and energy costs. 
Alternative solvents of extraction have been developed and studied over the years such as ionic liquids (ILs), ${ }^{21}$ deep eutectic solvents (DES), ${ }^{22,23}$ subcritical water (SCW), ${ }^{24}$ supercritical $\mathrm{CO}_{2}\left(\mathrm{SC}-\mathrm{CO}_{2}\right)^{25}$ or solvent-free (pressing, extrusion, ball milling, instant controlled drop pressure). ${ }^{26,27}$ However, after extraction, deep eutectic solvent and ionic liquid extracts often suffer from the impossibility to recover the solute by a simple evaporation of solvent. It requires then an additional step such as solid-liquid extraction, liquid-liquid extraction or adsorption on column or addition of an antisolvent. ${ }^{28,29}$ The physical extraction in the absence of solvent is generally not an efficient solution either since mechanical frictions induce high shearing and high temperature that can lead to the decomposition of heatlabile phenolic compounds and polymerization of phenolic compounds, reducing their extractability. ${ }^{30}$

Pressurized fluids such as subcritical water and supercritical carbon dioxide represent a very suitable alternative to the use of organic solvents. Water and carbon dioxide are cheap, available and non-toxic solvents. Subcritical water is perfectly adapted to recover polar and medium-polar solute and supercritical carbon dioxide is more adapted to recover apolar molecules. In a world aware of current and future environmental concerns, subcritical water and supercritical carbon dioxide represent top choice extraction solvents in the near future to reduce the environmental impact of the process.

Subcritical water (SCW) also called "superheated water", "hot compressed water" or "pressurized hot water" is liquid water at temperatures between $100{ }^{\circ} \mathrm{C}(373 \mathrm{~K})$ under 1 bar and $374{ }^{\circ} \mathrm{C}(647 \mathrm{~K})$ under 220 bars. This maximum temperature is related to the critical point of water that is reached at $374{ }^{\circ} \mathrm{C}$ and 220 bars when the heat of vaporization become equal to zero. The increase of temperature affects positively i) the diffusion coefficient of water, ii) the solubility of solutes, iii) the diffusion of solutes and iv) the water viscosity. In addition, a modification of specific physicochemical properties of SCW are observed such as i) the reduction of dielectric constant of water $\left(\varepsilon=80\right.$ at $25^{\circ} \mathrm{C}, \mathrm{P}_{\text {atm }}$ to $\varepsilon=27$ at $250{ }^{\circ} \mathrm{C}, 50$ bars) to become closer to that of ethanol $(\varepsilon=24)$ and methanol $(\varepsilon=33)$ and ii) the acidification of water by self-ionization of water molecules. ${ }^{31}$

Supercritical carbon dioxide $\left(\mathrm{SC}-\mathrm{CO}_{2}\right)$ means $\mathrm{CO}_{2}$ at the supercritical state, with pressure and temperature exceeding the critical point of $\mathrm{CO}_{2}$, relatively easy to reach at $31.1^{\circ} \mathrm{C}$ and 73.8 bars. The supercritical $\mathrm{CO}_{2}$ is in a homogeneous and hybrid state that presents both properties of liquids and gas. It reaches viscosities close to those of gas (0.02-0.12 mPa.s at $40{ }^{\circ} \mathrm{C}$ ) and its densities are close to those of liquids (700 to $\left.1100 \mathrm{~kg} \cdot \mathrm{m}^{-3}\right){ }^{32,} 33$ Variations of temperature and pressure allow to set the properties of supercritical $\mathrm{CO}_{2}$ and to fit with different applications. ${ }^{34}$ The most known extraction process with $\mathrm{CO}_{2}$ used as supercritical fluid is the RESS (Rapid Expansion of Supercritical Solution) method, consisting in a two-steps process with i) a first solubilization of the solute in $\mathrm{SC}-\mathrm{CO}_{2}$, followed by ii) a precipitation of the solute by oversaturation in $\mathrm{CO}_{2}$ gas. ${ }^{35}$
The aim of this review is to evaluate the contribution of subcritical $\mathrm{H}_{2} \mathrm{O}$ and supercritical $\mathrm{CO}_{2}$ for coffee and coffee byproducts valorization. The review article is thus organized in two main parts: i) the full description of the coffee and coffee by-products processes, composition and valorization (section 2) and ii) the benefits of subcritical $\mathrm{H}_{2} \mathrm{O}$ and supercritical $\mathrm{CO}_{2}$ for the valorization of coffee and coffee by-products (section $3)$.

\section{Coffee}

Coffee is one of the most consumed beverages over the world after water, and it is the second most traded commodity after petroleum. According to International Coffee Organization, 9.4 million of tons of green coffee beans have been produced in 2018. ${ }^{36}$ This raw resource is cheap, available and consequent amounts of by-products are resulting from the preparation of coffee beverage.

The following sections discuss the exploitation and the valorization of coffee and its by-products.

\subsection{Coffee exploitation}

Nowadays, $90 \%$ of coffee is produced in developing countries (Table 1). ${ }^{37}$ Brazil is the biggest producer of coffee bean with 2.68 million tons in 2018 and represent almost a third of the world coffee production (total production of 9.2 million tons). ${ }^{38}$ Close to 80 varieties of coffee exist, but two of them are mainly cultivated nowadays: Coffea canephora, mostly known as Robusta and Coffea arabica.

Arabica coffee from Brazil and South American countries represents around $75 \%$ of the world production whereas Robusta coffee from Vietnam and African countries coffee represents the remaining 25\%. Growing conditions of their trees are different. Arabica tree needs shade and soft temperatures, whereas Robusta tree can resist to harsh conditions of temperatures and humidity. Variation of composition is observed in terms of polysaccharides, lipids, bioactive molecules and caffeine as a function of the variety. For example, Arabica contains 0.8 to $1.5 \%$ of caffeine whereas Robusta contains 2.5 to $3.0 \%$ of this molecule. In any case, the treatment required for the transformation from green coffee bean to coffee beverage remains the same for both varieties.

\begin{tabular}{ccc}
\hline Table 1: The most important world coffee producers in 2018. \\
\hline & $\begin{array}{c}\text { Production } \\
\text { (million tons) }\end{array}$ & $\begin{array}{c}\text { Word production } \\
\text { (\%) }\end{array}$ \\
\hline Brazil & 2.68 & 29.1 \\
\hline Vietnam & 1.54 & 16.7 \\
\hline Colombia & 0.75 & 8.2 \\
\hline Indonesia & 0.67 & 7.3 \\
\hline Honduras & 0.47 & 5.2 \\
\hline Ethiopia & 0.47 & 5.1 \\
\hline Others & 2.62 & 28.4 \\
\hline
\end{tabular}

\subsection{Coffee treatments and composition}

Many processes are required before obtaining the beverage from the coffee cherry, leading to the formation of by- 
products (Table 2). In addition, those by-products are composed of caffeine, tannins and polyphenols that could be possibly toxic for the environment. ${ }^{39}$ After harvest coffee cherry, the three main steps required for obtaining the beverage are i) drying or wet process, ii) roasting process and iii) brewing process. ${ }^{10}$ Several by-products such as coffee husks $(\mathrm{CH})$, pulp, silverskin (CSS) and spent coffee grounds (SCG) result from the processes of coffee treatment (Figure 1) that have been largely described in literature. ${ }^{10}$

Dry or wet processes aim to extract the core of coffee cherry and to recover the green coffee bean. Dry method also called cherry method consists in drying and mixing the freshly harvested coffee cherry for 12-15 days until it is totally dry. ${ }^{10}$ The peel removed during the dry process is called coffee husk. About 0.18 ton of husk is produced for 1 ton of coffee cherry. The husk is composed of more than $70 \%$ of carbohydrates, about $15 \%$ moisture, $7.0 \%$ protein, $5 \%$ ash, $0.3 \%$ lipids, and about $0.65 \%$ of caffeine $(\mathrm{w} / \mathrm{w}) .{ }^{10}, 40$ Wet method consists in removing coffee cherry pulp with a pulper before drying operation that longs 24 to $36 \mathrm{~h}$ for Arabica and $72 \mathrm{~h}$ for Robusta. When process is the wet method the coffee is called washed or parchment coffee. The pulp recovered during the wet process is called coffee pulp. About 0.33 ton of pulp is produced for 1 ton of coffee cherry. The pulp is composed of $50 \%$ carbohydrates, $20 \%$ fibers, $10 \%$ proteins, $5 \%$ tannins $2 \%$ lipids and $1.3 \%$ caffeine $(\mathrm{w} / \mathrm{w}) .^{41}$

Green coffee beans obtained are composed of about 30 $50 \%$ of insoluble polysaccharides, $10 \%$ of soluble carbohydrates, $10-15 \%$ of lipids, $10 \%$ of proteins, $6-12 \%$ of chlorogenic acids and $0.8-4 \%$ of caffeine $(w / w)$. Contents in lipids and insoluble polysaccharides are higher for Arabica whereas contents in chlorogenic acids and caffeine are higher for Robusta. ${ }^{42}$ Despite this interesting composition, green coffee bean is tasteless and odorless and a roasting process is necessary to give it flavor and odor.

Table 2: Composition of green coffee and coffee by-products.

\begin{tabular}{cccccc}
\hline & $\begin{array}{c}\text { Sugars } \\
\%\end{array}$ & $\begin{array}{c}\text { Lipids } \\
\%\end{array}$ & $\begin{array}{c}\text { Proteins } \\
\%\end{array}$ & $\begin{array}{c}\text { Caffeine } \\
\%\end{array}$ & $\begin{array}{c}\text { Chlorogenic } \\
\text { acids \% }\end{array}$ \\
\hline GCB & $40-60$ & $10-15$ & 10 & $0.8-4$ & $6-12$ \\
\hline CH & 70 & 0.3 & 7 & 0.65 & $/$ \\
\hline CP & 70 & 2 & 10 & 1.3 & $/$ \\
\hline CSS & 60 & 2 & 18 & $0.8-1.3$ & $/$ \\
\hline SCG & $45-50$ & $10-15$ & $7-13$ & $0-0.5$ & $0.5-3$
\end{tabular}

Roasting process consists in a pyrolysis of the green coffee beans at 200 to $250{ }^{\circ} \mathrm{C}$ during 0.75 to $25 \mathrm{~min}$. Many of the compositional changes occur during this step and are due to the Maillard reaction that gives thus to the coffee beans their aromas. ${ }^{43}$ Roasting step also removes a peel to beans that is called coffee silverskin. Although it only represents $1 \%$ of initial mass, ${ }^{10}$ the large amounts of coffee beans that are roasted make it an important by-product of coffee production. Coffee silverskin is composed of $60 \%$ carbohydrates, $18 \%$ proteins, $2 \%$ lipids, $7 \%$ ashes, $7 \%$ moisture and $0.8-1.3 \%$ caffeine $(w / w) .{ }^{44}$ Roasted coffee beans obtained keep almost same composition as green coffee beans in terms of carbohydrates, lipids and proteins. Main differences are the important degradation of chlorogenic acids, up to $90 \%$ and caffeine, up to $25 \%$ depending on the roasting intensity that can be light, medium or dark. ${ }^{45}$

Main products

By-products
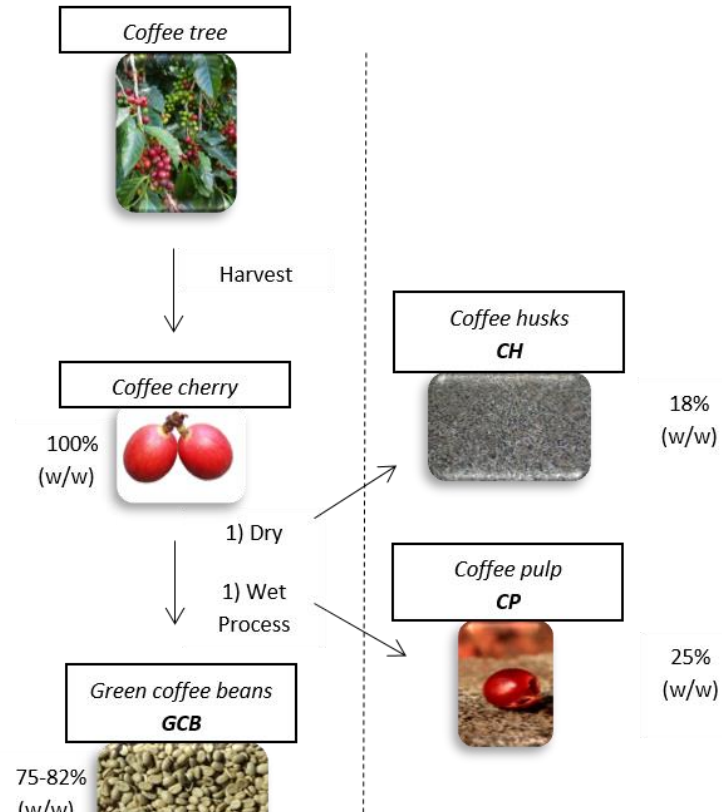

$25 \%$

$(w / w)$

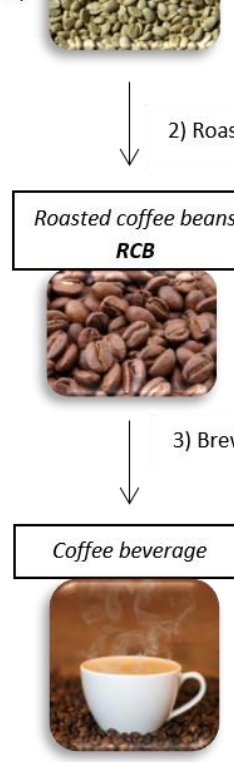

Figure 1: Coffee processes and their by-products.

To finally obtain coffee beverage, grinding and brewing process are required. Brewing process consists in an extraction with water at $100{ }^{\circ} \mathrm{C}$. Boiling water is flowed through the grinded roasted coffee beans by gravity or under pressure giving a flavored coffee beverage. Remaining grinded roasted coffee beans that are not soluble in water and constitute then a solid waste with high moisture content that is called spent coffee grounds. Thereby, 0.65 ton of spent coffee grounds is produced for 1 ton of green coffee beans. ${ }^{10}$ The spent coffee grounds is composed of $45-50 \%$ 
carbohydrates, $\quad 10-15 \%$ lipids, $\quad 7-13 \%$ proteins, $\quad 0.5-3 \%$ chlorogenic acids and $0-0.5 \%$ caffeine $(\mathrm{w} / \mathrm{w}) .{ }^{46}$

\subsection{Valorization of coffee and coffee by-products}

The valorization of coffee and coffee by-products is mainly related to i) their chemical composition and ii) their availability, accessibility and quantity generated.

Despite the discrepant composition between green coffee bean (GCB), coffee husk (CH), coffee pulp (CP), coffee silverskin (CSS) and spent coffee grounds (SCG), similar way of valorization are studied since the nature and proportion are quite similar between the different coffee by-products $\mathrm{CH}, \mathrm{CP}, \mathrm{CSS}$ and SCG (Table 2). ${ }^{47}$ Main difference of way of valorization is related to the high lipidic content of GCB and SCG. GCB is also atypical with high chlorogenic acid content. The concentration of high molecular mass molecules (HMM) such as melanoidins increases in coffee beans after roasting due to Maillard reaction. ${ }^{43}, 48$ The concentration of chlorogenic acids significantly decreases after roasting, hence, the antioxidant activity remains similar. ${ }^{48}$ This is due to the formation of Maillard reaction products and transformation of chlorogenic acids into derivatives such as chlorogenic acids, lactones or phenylindans that exhibit high antioxidant properties. ${ }^{48,49}$ As a consequence, even if CSS and SCG present different chemical composition of polyphenols compared to $\mathrm{GCB}, \mathrm{CH}$ and $\mathrm{CP}$, the way of valorization into high antioxidant extract remains the same (Table 3 ).

As presented in Figure 1, SCG is the main coffee byproduct representing $49-53 \% \mathrm{w} / \mathrm{w}$ of the coffee fruit, followed by coffee pulp $(25 \% \mathrm{w} / \mathrm{w})$, coffee husk $(18 \% \mathrm{w} / \mathrm{w})$ and coffee silverskin ( $1 \% \mathrm{w} / \mathrm{w})$.

In addition, coffee by-products are produced at different stages of coffee processes resulting in major differences of their accessibility. For example, coffee husk and coffee pulp are generated by coffee growers, limitating geographically the valorization of such by-products to coffee producer countries. Coffee silverskin are obtained all around the globe but only roaster companies are generating this by-product. Spent coffee grounds are produced all over the planet by everybody, in particulars in household, coffeeshops, hotels or soluble coffee industries. Then, the possibility to give higher economic value to this waste is not only valuable for industry but also for the collectivities and public authorities, especially in terms of waste management. ${ }^{50}$

\subsection{Characterization of coffee and coffee by-products} extracts

Numerous technics of characterizations are used to evaluate the nature of the final product like antioxidant extract or biocrude oil. The following section gives a brief description of all the major analysis performed with coffee extracts in order to better discuss the effects of subcritical $\mathrm{H}_{2} \mathrm{O}$ and supercritical $\mathrm{CO}_{2}$.

\subsubsection{Carbohydrates extracts}

Total Sugar Content (TSC)

The total sugar content (TSC) is a colorimetric test in food science that aims to measure all carbohydrates such as mono, di-, oligo-, polysaccharides, proteoglycans, glycoproteins and glycolipids without distinguishing the nature of the species. ${ }^{51}$ Two simple procedures have been developed as phenol-sulfuric acid assay also called "Dubois method" 52,53 and anthrone-sulfuric acid. ${ }^{54-56}$ The phenol and anthronesulfuric tests lean on the hydrolysis of sugars into furfural or hydroxymethyl furfural that form a conjugated system with phenol or anthrone. The result is expressed with a calibration curve of glucose ( $\mathrm{g}_{\mathrm{GLU}} \cdot \mathbf{1 0 0}_{\mathrm{g}}$ dry material). For lignocellulosic material, this assay is efficient i) to define the total sugars of a biomass or ii) to evaluate the influence of extraction parameters on the sugar content of a produced extract.

\section{Reducing Sugars (RSs)}

A reducing sugar is defined as any sugar reacting as reducing agent because of a free aldehyde or free ketone function its bears. As such, all monosaccharides are considered as reducing sugar. It is important to note that monosaccharides are dietary sugars with applications in agrifood and nutraceutical. Furthermore, the transformation step for the production of reducing sugar from lignocellusic material is called the saccharification. It is generally performed by enzymatic, or acid or alkaline hydrolysis. The saccharification is the preliminary step before the transformation of reducing sugars into bioethanol.

The "Reducing Sugars" (RSs) is a colorimetric assay in food science that aimed to measure all the reducing sugars without distinguishing between species (DNS method). ${ }^{57,} 58 \mathrm{RSs}$ is a relevant test to i) determine dietary sugars amount in an extract and ii) to evaluate the interest of subcritical $\mathrm{H}_{2} \mathrm{O}$ to induce saccharification.

\section{Sugar profile}

Lignocellulosic material is a complex matrix of lignin, hemicellulose and cellulose. Di-, oligo-, polysaccharides such as hemicellulose and cellulose are macromolecules composed of 2 (di-), 3-10 (oligo-) or > 10 (poly-) monosaccharides building blocks. Cellulose is a homopolymer composed of 100-3000 glucose molecules combined at the $\beta(1 \rightarrow 4)$ position. Hemicellulose is a heteropolymer that can be composed of glucose, xylose, mannose, galactose, rhamnose or arabinose. Coffee polysaccharides are mainly composed of galactose, mannose, glucose and arabinose patterns. ${ }^{59}$

The nature of those monosaccharides can be determined after hydrolysis of the biomass or extract by HPLC with Refractive Index (RI), ${ }^{60}$ Evaporative Light Scattering Detection (ELSD), ${ }^{61}$ Electrochemical Detection $(E C D)^{62}$ or UVVisible/Diode Array Detector (DAD) after derivatization with 1-phenyl-3-methyl-5-pyrazolone (PMP). ${ }^{63,64}$

Equation 1: Sugar profile.

Sugar profile $=\frac{\text { Amount of specific sugar }}{\text { Amount of total specific sugar }} \times 100$

Many other chromatographic method have also been studied in the literature. ${ }^{65}$ Sugar properties are related to their chemical structure Hence, the determination of sugar profile (Equation 1) is relevant i) to define the chemical 
structure of sugars in extract and ii) to evaluate the influence of SCW on the sugars extraction selectivity or their in-situ transformation. 


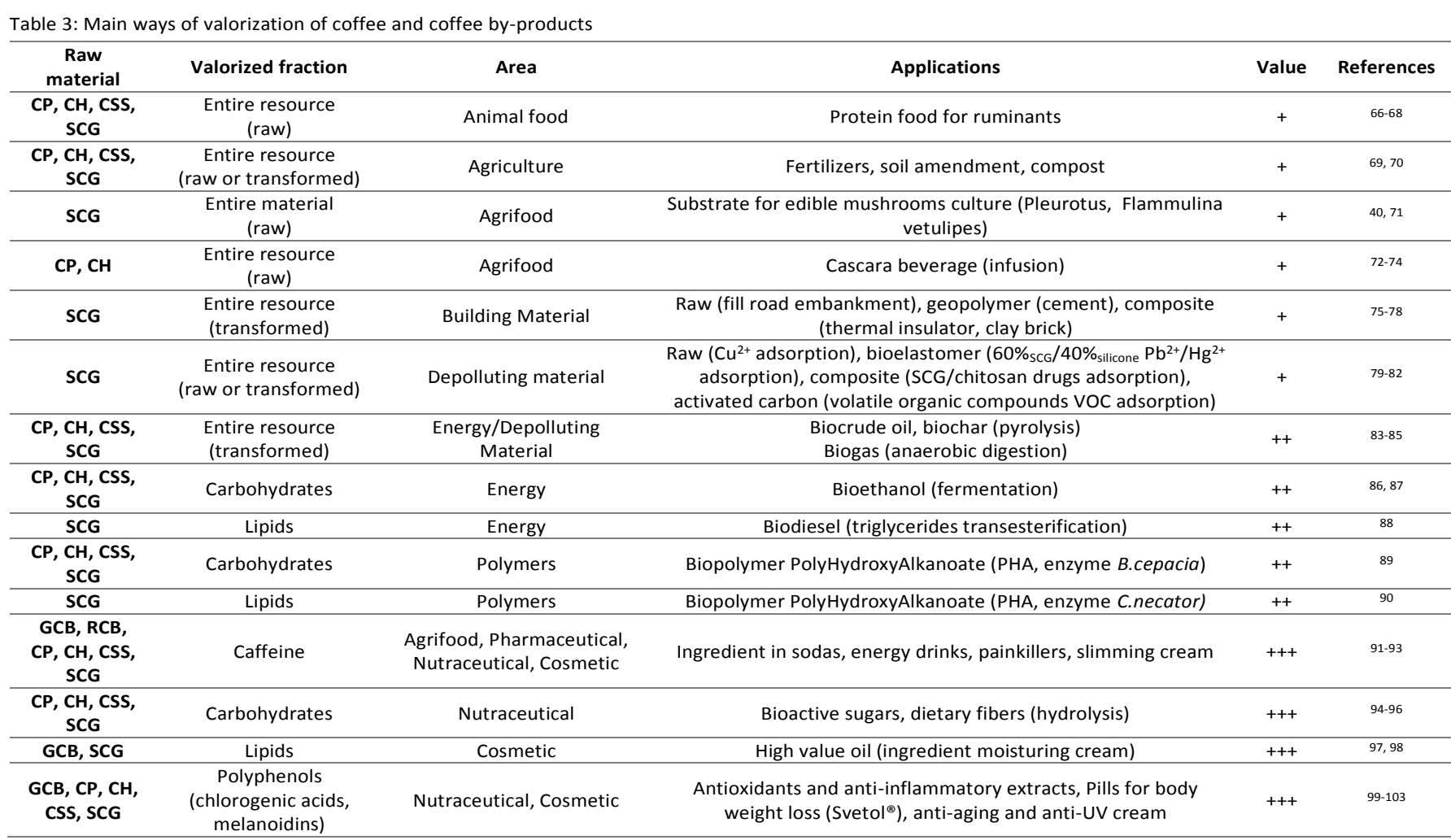

\subsubsection{Antioxidant extracts:}

\section{Total Polyphenol Content (TPC)}

The Total Polyphenol Content (TPC) also called "FolinCiocalteu assay" is a colorimetric assay in food science that aims measuring the total polyphenols without distinguishing the species. ${ }^{99,} 104$ The result is expressed with a calibration curve of standard like gallic acid ( $\mathrm{mg}_{\mathrm{GAE}} \cdot \mathrm{g}^{-1}$ extract or $\mathrm{mg}_{\mathrm{GAE}} \cdot \mathrm{g}^{-1} \mathrm{dry}$ matter or $\left.\mathrm{mg}_{G A E} \mathrm{~L}^{-1}\right)$ that is the most common standard. Some papers also refer the use of caffeic acid or catechin as standards.

\section{Total Flavonoid Content (TFC)}

The Total Flavonoid Content (TFC) is a colorimetric assay in food science that aims measuring the total flavonoids without distinguishing the species. ${ }^{105,} 106$ The assay is based on the complexation of aluminium $\left(\mathrm{AlCl}_{3}\right)$ with flavonoids. Two main procedures have been described in the literature ${ }^{105}$ The result is expressed via the calibration of standard such as catechin, quercetin or rutin for examples.

\section{Antioxidant Capacity (AOC)}

Antioxidant Capacity (AOC) assay is a colorimetric assay that aims measuring the level of oxidative species inhibition of a solution or extract. Several tests have been developed such as 2,2-diphenyl-1-picrylhydrazyl (DPPH), ferric ion reducing antioxidant power (FRAP) and/or 2,2'-azino-bis(3ethylbenzothiazoline-6-sulfonic acid) (ABTS), oxygen radical absorbance capacity (ORAC) assays. ${ }^{107,108} \mathrm{DPPH}$ results have been reported as percentage of radical inhibition like DPPH
(Table 4, Entries 3 and 4), ${ }^{109}$ half effective concentration $\mathrm{EC}_{50}$ (Table 4, Entry 5$)^{110}$ or inhibition concentration at $50 \% \mathrm{IC}_{50}$ (Table 4, Entry 15). ${ }^{111} \mathrm{IC}_{50}$ or $\mathrm{EC}_{50}$ is the most used expressed result of DPPH with calibration curve of Trolox, an antioxidant specie. The use of Trolox is also reported in literature as Trolox Equivalent Antioxidant Capacity (TEAC) for the different antioxidant capacity assays (DPPH, ABTS, FRAP, ORAC). TEAC can be expressed in $\mu \mathrm{mol}_{\mathrm{TE} . \mathrm{g}^{-1}}, \mathrm{mmol}_{\mathrm{TE}} \mathrm{g}^{-1}$, $\mu \mathrm{g}_{\mathrm{TE}} \cdot \mathrm{g}^{-1}$ or $\mathrm{mg}_{\mathrm{TE}} \cdot \mathrm{g}^{-1}$, (Table 4, Entry 1 ). ${ }^{112}$ Otherwise, another standard such as ascorbic acid equivalent in $\mathrm{mmol}_{\mathrm{AAE}} \cdot \mathrm{g}^{-1}$ or $\mu \mathrm{mol}_{\text {AAE }} \mathrm{g}^{-1}$ is also used (Table 4, Entry 6). ${ }^{113}$

\section{High Performance Liquid Chromatography (HPLC) -} Polyphenols

Chlorogenic acids are the main polyphenols in coffee and coffee by-products. ${ }^{114,115}$ Chlorogenic acids are composed of hydroxycinnamic acids like caffeic, coumaric or ferulic acids bonded to the $-\mathrm{OH}$ function of quinic acid core in position 3 , 4 or 5 (Figure 2 ).<smiles>O=C(/C=C/c1ccc(O)c(O)c1)O[C@H]1C[C@H](O)C[C@H](O)[C@H]1O</smiles>

Figure 2: Main polyphenols in coffee and coffee by-products.

Hence, chlorogenic acids can be quantified by HPLC-MS or HPLC-DAD (325 $\mathrm{nm})$ in equivalent of one marketed chlorogenic acid, 5-caffeoylquinic acid. ${ }^{116}$ Secondary polar 
metabolites from methylxanthines, flavonoids, and anthocyanins families have been observed in the extracts by HPLC-UV. The major secondary metabolites identified and quantified in coffee extracts are caffeine (methylxanthines) and catechin (flavonoids) at $280 \mathrm{~nm}$ and cyanidin-3-rutinoside (anthocyanins) at $520 \mathrm{~nm}$ (Figure 3) .117-119

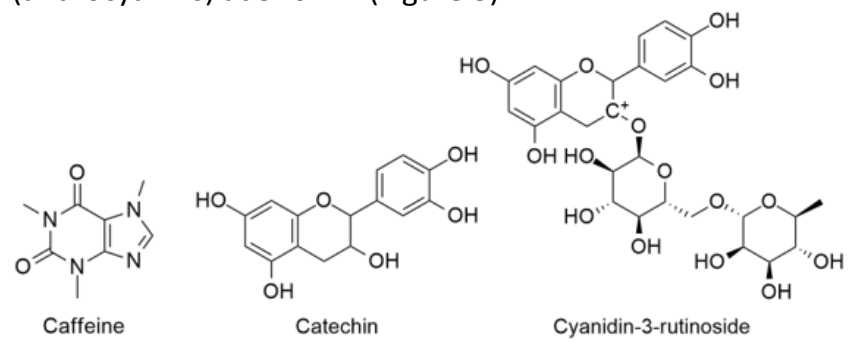

Figure 3: Main secondary metabolites in coffee and coffee by-products.

\subsubsection{Biocrude oil and biochar:}

Higher Heating Value (HHV)

The heating value also called "calorific value" or "heat of combustion" is defined as the energy content of a biomass fuel. This parameter is considered as one of the most important characteristic parameters for designing calculations and numerical simulations of thermal system. ${ }^{120}$ The largest heating value (HHV) refers to the heat released from the fuel combustion with the original and generated water in a condensed state. ${ }^{120} \mathrm{HHV}$ is usually expressed in MJ.kg-1.

\section{Energy Yield Recovery}

The energy yield recovery is defined as the yield of remaining energy after the transformation of the raw material into a biocrude oil or biochar (Equation 2). This result is as much important as the HHV of the final product.

Equation 2: Energy yield recovery formula.

Energy yield recovery $=\frac{H H V \text { fuel } \times \text { fuel mass }}{H H V \text { raw material } \times \text { raw material mass }} \times 100$

\subsubsection{Lipid extracts:}

Yield of extraction (relative and absolute)

The yield of extraction is defined by two different expressions: relative and absolute yields (Equations 3 and 4).

Equation 3: Equation of relative yield

$$
\text { Relative yield }=\frac{\text { oil mass extracted by } \mathrm{SC}-\mathrm{CO}_{2}}{\text { oil mass extracted by hexane Soxhlet }} \times 100
$$

Equation 4: Equation of absolute yield.

$$
\text { Absolute yield }=\quad \frac{\text { oil mass extracted by } \mathrm{SC}-\mathrm{CO}_{2}}{\text { raw material mass }} \times 100
$$

In the studied literature, $\mathrm{SC}-\mathrm{CO}_{2}$ is considered as an apolar solvent, able to remove exclusively apolar solute i.e. the lipidic fraction composed mainly of triglycerides. Hence, for relative yield, the yield of extraction of $\mathrm{SC}-\mathrm{CO}_{2}$ is compared to the yield obtained by hexane with Soxhlet system, considering as a reference method for lipid extraction. ${ }^{121}$ The relative yield presents the huge advantage of evaluating and comparing properly the operating conditions of $\mathrm{SC}-\mathrm{CO}_{2}$ described in the literature about same biomass, and this despite the difference of chemical composition.

The absolute yield remains an interesting measurement to define the quantitative amount of lipid fraction in biomass by hexane Soxhlet extraction or $\mathrm{SC}-\mathrm{CO}_{2}$ extraction. Absolute yield can also be used to compare operation conditions within the same study.

\section{Fatty Acid Composition (FAC)}

Oleaginous are plant materials including seeds or fruits rich in fats. Those vegetable fats are mainly composed of triglycerides, also called triacylglycerols, which are esters of glycerol bonded to fatty acids. Triglycerides of green coffee beans and spent coffee grounds represent by themselves $75 \%$ of the total fats. ${ }^{122}$ Fatty acids in spent coffee grounds and green coffee beans have been reported to be mainly palmitic (C16:0) and linoleic (C18:2) acids, followed by stearic (C18:0) and oleic (C18:1) acids (Figure 4). ${ }^{122}$
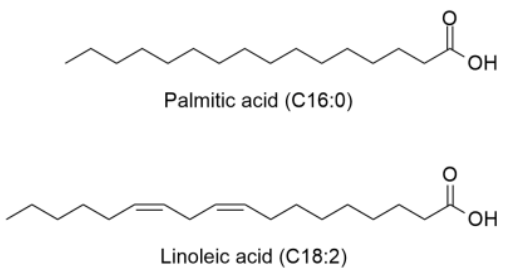

Figure 4: Main fatty acids pattern of triglycerides in coffee and coffee byproducts.

The nature and profile of those fatty acids in triglycerides can be determined by Gas Chromatography - Flame Ionization Detector. More precisely, only fatty acid methyl esters (FAME) obtained by transesterification or methanolysis of triglycerides with $\mathrm{MeOH}$ and an acid catalyst $\left(\mathrm{HCl}, \mathrm{H}_{2} \mathrm{SO}_{4}\right)$ are analyzed. ${ }^{123,124}$

\section{Terpenoids, sterols and tocopherols}

Coming mainly from plant kingdom, the bioactive terpenes and terpenoids are the most important constituents of essential oils. Terpenes are naturally occurring as hydrocarbon based on combinations of the isoprene units. Terpenoids are terpenes that have been denaturated by oxidation, including oxygen functions. Main terpenoids of coffee reported in literature are: kahweol, cafestol, 16-Omethylcafestol (Figure 5). ${ }^{122}$
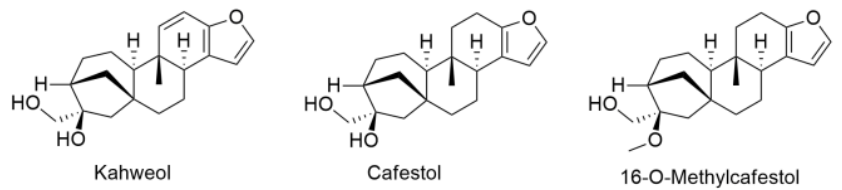

Figure 5: Main terpenoids in coffee and coffee by-products. 
Phytosterols also called "natural" sterols are a family of sterols found in the fat fraction of plant kingdom. Sterols are lipid molecules composed of a sterane core, with hydroxyl function linked to the third carbon. Main sterols of coffee reported in literature are: campesterol, stigmasterol and $\beta$ sitosterol (Figure 6). ${ }^{122}$

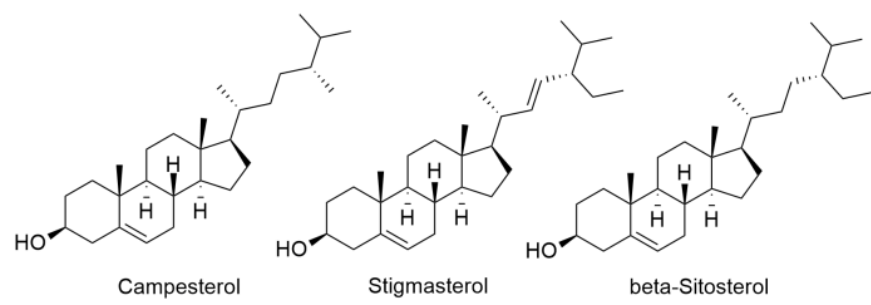

Figure 6: Main sterols in coffee and coffee by-products

Vitamin $E$ is a vitamin that regroups four forms of tocopherol and four forms of tocotrienol. Tocopherols are antioxidant lipophilic molecules present in abundance in vegetable oils. Tocopherols are composed of chromanol core bonded to a lateral chain of sixteen saturated carbons. Main tocopherols of coffee reported in literature are: $\alpha$ - and $\beta$ tocopherol (Figure 7). ${ }^{122}$

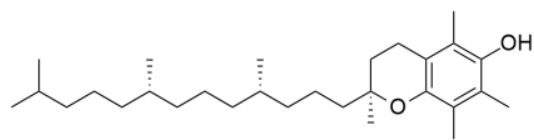

alpha-Tocopherol

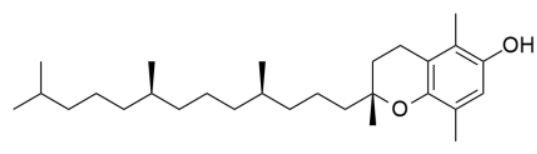

beta-Tocopherol

Figure 7: Main tocopherols in coffee and coffee by-products.

In natural material, terpenes, terpenoids, sterols and tocopherols can be found conjugated to fatty acid or acyl derivatives as esters. ${ }^{125}$ Hence, saponification has to be performed before further HPLC-UV or HPLC-DAD analysis. ${ }^{125}$

The analysis of terpenoids, sterols and tocopherols in coffee oil is of high order to evaluate oil bioactivity. Indeed, terpenoids have demonstrated antihypertensive, anticancer (Taxol), antifungal and antimicrobial properties. ${ }^{97,} 126$ This results are reported by more than 2000 patents between 1980-2003 for terpenoids applied in pharmaceutic and cosmetic field. ${ }^{127}$

Strong rates of LDL-cholesterol are responsible for clogging the coronary arteries, leading to cardiovascular disease. Phytosterols have been demonstrated to lowering by 5 to $15 \%$ concentration of LDL-Cholesterol in human body, resulting in applications in pharmaceutic, cosmetic and nutraceutic fields. ${ }^{128}$

Tocopherols are responsible for protecting membranes against lipids peroxidation, which could slow the aging process in humans or animals. ${ }^{129}$ Moreover, tocopherols also exhibit photoprotective properties in cosmetic cream, usefulness to treat Parkinson disease and eye disease or prevent negative effects of ischemia-reperfusion.

\section{Pressurized fluids applied to coffee and coffee by-products}

This section discusses the different results reported in the literature during the last decades and focused on coffee and coffee by-products valorization using subcritical $\mathrm{H}_{2} \mathrm{O}$ and supercritical $\mathrm{CO}_{2}$. It also highlights the new and future trends and applications of pressurized fluids in this field of research.

\subsection{Subcritical Water (SCW)}

Table 4 reports examples involving the use of SCW for coffee or coffee by-products valorization. The roasted coffee valorization by SCW, widely investigated at the end of the $\mathrm{XX}^{\text {th }}$ century, ${ }^{21,26}$ has not been reported in this Table 4 .

Most of the studies dedicated to the use of subcritical $\mathrm{H}_{2} \mathrm{O}$ for coffee and coffee by-products valorization described in the literature report the use of spent coffee grounds as raw material, in $70 \%$ of reported cases.

Table 4 shows the wide diversity of compounds that are obtained using SCW for coffee and coffee waste valorization. They can be classified into three groups depending on what they will be intended for: i) carbohydrate extracts; ii) antioxidant extracts $(75 \%$ of the reported cases from the literature); ii) biocrude oils and biochars.

\subsubsection{Carbohydrate valorization}

Extraction of carbohydrates with subcritical $\mathrm{H}_{2} \mathrm{O}$ has been widely investigated. For spent coffee grounds (SCG), Chun et al. have reported best Total Sugar Content (TSC) results of $47.7 \mathrm{~g}_{\mathrm{GLU}} \cdot 100 \mathrm{~g}^{-1}$ extract after an ultrasonic pretreatment (20 $\mathrm{kHz}, 750 \mathrm{~W}$ output power), for 5 min of extraction at $180{ }^{\circ} \mathrm{C}$ and 20 bars (Table 4, Entry 14). ${ }^{130}$ Those results can be explained by benefits of hydrothermal extraction combined with ultrasonic pretreatment used. In fact, authors suggest that ultrasonic pretreatment $(20 \mathrm{kHz}, 750 \mathrm{~W}$ output power) facilitates the extraction of carbohydrates by increasing mass transfer from SCG to solvent media. In addition, the pretreatment could make it possible to avoid the use of extreme conditions, responsible of degradation products.

Chun et al. have reported the use of modifiers such as $\mathrm{CO}_{2}$ and $\mathrm{N}_{2}$ with subcritical $\mathrm{H}_{2} \mathrm{O}$ for the extraction of carbohydrates (Table 4, Entry 2). ${ }^{131}$ Maximal RSs (37.91 g. $100 \mathrm{~g}^{-1}$ extract) have been observed at $220{ }^{\circ} \mathrm{C}$ with $\mathrm{N}_{2}$. The authors have proposed that the presence of nitrogen in SCW extraction can act as a shield against the reaction with atmosphere. At contrary, at the same $220^{\circ} \mathrm{C}$ temperature, subcritical $\mathrm{H}_{2} \mathrm{O}$ with $\mathrm{CO}_{2}$ has resulted in lower RSs. For the authors, the onset of the formation of reducing sugars required a lower residence times due to the faster cleavage of glycosidic bonds due to carbonic acid formation of $\mathrm{CO}_{2}$ in water. Then, the $\mathrm{CO}_{2} / \mathrm{H}_{2} \mathrm{O}$ technology is gaining interest in the 
field of biomass valorization to improve lignocellulosic fractionation. ${ }^{132}$

Simões and Paiva et al. have also reported a semicontinuous extraction ( $10 \mathrm{~mL} \cdot \mathrm{min}^{-1}$ ) during $180 \mathrm{~min}$ with a low total sugar content around $3 \mathrm{~g}_{\mathrm{GLU}} \cdot 100 \mathrm{~g}^{-1} \mathrm{sCG}$ at $150{ }^{\circ} \mathrm{C}$ and $30 \mathrm{gGLU} 100 \mathrm{~g}^{-1} \mathrm{sCG}$ at $200{ }^{\circ} \mathrm{C}$ (Table 4, Entry 12). ${ }^{133}$ They have shown that SCG has low soluble amount of sugars due to the coffee brewing process. Simões and Paiva et al. have suggested that subcritical $\mathrm{H}_{2} \mathrm{O}$ at $200{ }^{\circ} \mathrm{C}$ acts as reagent performing the depolymerization of lignocellulosic matrix leading to the release of structural carbohydrates. Furthermore, their researches have proved that monosaccharides represent less than $5 \%$ of the total carbohydrates, concluding that subcritical $\mathrm{H}_{2} \mathrm{O}$ has hydrolyzed the polysaccharides into oligomers, rather than to monomers. However, another hypothesis could be that a larger amount of monosaccharides has been produced and degraded at the same time. Indeed, the main products of degradation of hexoses in subcritical $\mathrm{H}_{2} \mathrm{O}$ have been demonstrated to be 5-hydroxymethyl-2-furaldehyde (5-HMF) and furfural (Figure 8). ${ }^{134,135}$

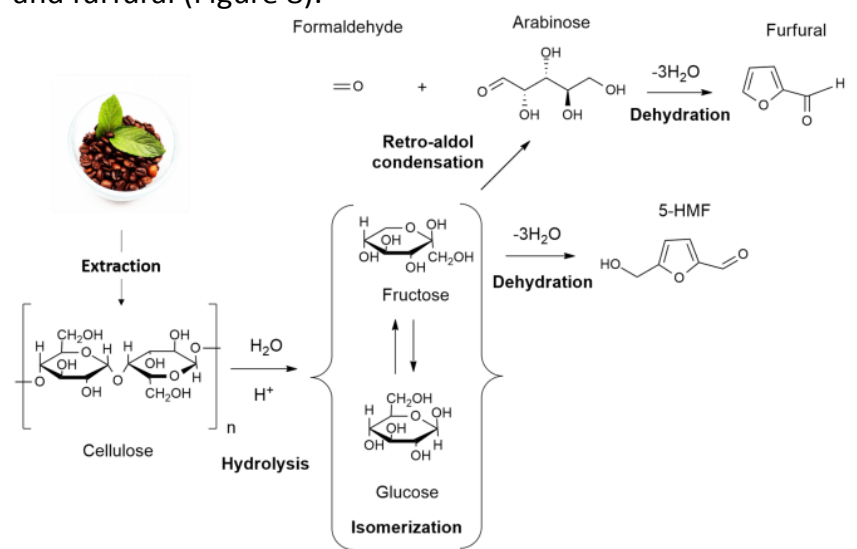

Figure 8: Extraction and degradation mechanism of cellulose in subcritical $\mathrm{H}_{2} \mathrm{O}$ adapted from Banerjee and Goud et al., Aida et al., Lü et al. ${ }^{134,136,137}$

However, the self-ionization of $\mathrm{H}_{2} \mathrm{O}$ into $\mathrm{H}_{3} \mathrm{O}^{+}$and $\mathrm{HO}^{-}$can be also important in subcritical $\mathrm{H}_{2} \mathrm{O}\left(\mathrm{pH}=5.5\right.$ at $250{ }^{\circ} \mathrm{C}, \mathrm{pH}=$ 7 at $25^{\circ} \mathrm{C}$ ) to act as catalyst for chemical reactions, such as hydrolysis of carbohydrates including hemicellulose and cellulose. ${ }^{140}$ Forster-Carneiro et al. has reported that the dielectric constant, the viscosity and the surface tension have been reported to decrease for water above $100{ }^{\circ} \mathrm{C} . .^{138} \mathrm{King}$ et al. have observed that the diffusion rate increase under these conditions. ${ }^{139}$ In addition, they also have noted that glucose solubility is five-fold times higher in water at $180^{\circ} \mathrm{C}$ compared to $100{ }^{\circ} \mathrm{C} .{ }^{139}$

Mussatto et al. have reported the influence of subcritical $\mathrm{H}_{2} \mathrm{O}$ on the distribution of monosaccharides pattern in extracts (Table 4, Entry 15). ${ }^{111}$ They have found that in every extracts, galactose was the main monosaccharides and arabinose the less representative. Authors have suggested that galactomannan and arabinogalactan are initially present in the SCG. Mussatto et al. have also reported the temperature influence on the sugar composition with $48 \% / 32 \% / 10 \% / 10 \%\left(160{ }^{\circ} \mathrm{C}, 30 \mathrm{~min}\right)$ and $47 \% / 17 \% / 28 \% / 8 \%$ $\left(180^{\circ} \mathrm{C}, 30 \mathrm{~min}\right.$ ) of galactose/mannose/glucose/arabinose in the extracts. The main difference of composition between mannose and glucose has not been explained by the authors. To the best of our knowledge, four hypotheses can be proposed to explain these results obtained at $180{ }^{\circ} \mathrm{C}$ : i) the hydrolysis on cellulose or hemicellulose containing glucose pattern that could be more selective, ii) the kinetic of the degradation that may be faster for mannose than for glucose, iii) the isomerization reaction of monosaccharides that may occur; iv) hypotheses i), ii) and iii) can occur simultaneously. Even if the kinetic of hydrolysis of cellulose has been investigated, ${ }^{141}$ no publication reported in the literature can support the hypothesis i), since no publication reports the comparison of kinetic hydrolysis between galactan, mannan, arabinan and glucan or heteropolymers. ${ }^{135}$ In addition, kinetics of polysaccharides hydrolysis have been observed to be different depending on the degree of polymerization. ${ }^{142}$ The hypothesis ii) is documented by the literature demonstrating the difference of kinetic degradation of several monosaccharides such as glucose, galactose and mannose. ${ }^{135}$ However, similar rates of degradation for glucose and mannose have been reported at $220{ }^{\circ} \mathrm{C} .{ }^{135}$ The hypothesis iii) has been supported by literature. Monosaccharides under subcritical ethanol/water and under SCW lead to an epimerization of glucose/mannose. ${ }^{134,143}$

Subcritical $\mathrm{H}_{2} \mathrm{O}$ extractions have been compared to traditional chemical extraction such as alkaline treatment. ${ }^{144}$ Mussatto et al. have used an alkaline treatment of $4 \mathrm{M} \mathrm{NaOH}$ at $25{ }^{\circ} \mathrm{C}$ overnight and have obtained interesting TSC results of $39.0 \mathrm{gGLU} 100 \mathrm{~g}^{-1}$ extract. ${ }^{144}$ The authors have specified that the extraction parameters have not been optimized. Despite significant results i) the yields are lower than the best result obtained under subcritical $\mathrm{H}_{2} \mathrm{O}$ (47.7 $\left.\mathrm{g}_{\mathrm{GLU}} \cdot 100 \mathrm{~g}^{-1}\right)$ with pretreatment and ii) the use of $\mathrm{NaOH}$ generates a significant amount of salts that makes difficult the valorization of polyphenols after carbohydrates precipitation.

Based on the studies reported in Table 4, supplementary knowledge is required since the system looks like a black box where only the final results are considered. Several phenomena are known to operate at the same time without knowing the specific influence of i) solubilization at high temperature of already soluble carbohydrate in subcritical $\mathrm{H}_{2} \mathrm{O}$ without hydrolysis, ii) hydrolysis of polysaccharides into oligosaccharides, then into monosaccharide, iii) chemical reactions such as dehydration due to acid subcritical $\mathrm{H}_{2} \mathrm{O}$ that act as reagent and iv) chemical reactions such as decarboxylation due to thermal degradation.

To conclude, the subcritical $\mathrm{H}_{2} \mathrm{O}$ appears to be the most suitable, efficient and competitive solution to perform hydrolysis and extraction of carbohydrates from coffee and coffee byproducts with high yields and low environmental impact.

\subsubsection{Polyphenols valorization:}

\subsubsection{Extraction of the main polyphenols}

Extraction of polyphenols with subcritical $\mathrm{H}_{2} \mathrm{O}$ has been investigated (Table 4, Entries 1, 5-12 and 17). Chlorogenic acids (Figure 2) constitute the most important family of 
polyphenols, mostly responsible of Total Polyphenol Content (TPC) and AntiOxidant Capacity (AOC) values. Among them, $n$ caffeoylquinic acids (CQA) represent the most studied molecules in coffee and coffee by-products extraction. ${ }^{145}$ Clifford fully have investigated chlorogenic acids, a family of molecules composed of a quinic acid core, acylated with one or more caffeoyl groups. ${ }^{115}$ Chlorogenic acids such as CQA and di-CQA are predominant, these two compounds are about 120 times more concentrated $\left(43.52 \mathrm{mg}^{-1} \mathrm{~g}^{-1}\right)$ than free caffeic acid in spent coffee grounds extract $\left(0.36 \mathrm{mg} \cdot \mathrm{g}^{-1}\right){ }^{146}$

Simões and Paiva et al. have reported a subcritical $\mathrm{H}_{2} \mathrm{O}$ semi-continuous extraction of polyphenols (Table 4, Entry 12). ${ }^{133}$ At 200 and $220{ }^{\circ} \mathrm{C}$, they have recovered more polyphenols in comparison to classical hydroalcoholic extraction as reference method. According to the authors, this improvement may be explained by i) the release of phenolic compounds entrapped within the SCG matrix and ii) the potential degradation of lignin into phenolic compounds.

Gao et al. have reported that an increase of the temperature leads to an enhancement of the diffusion coefficient of solvent, solubility of solutes, diffusion rate of analytes, and a reduction of solvent viscosity and surface tension. ${ }^{112}$ They have also pointed out from literature that the dielectric constant close to methanol may enhance the solubility of phenolic compounds. However, the concentration of n-CQA (3, 4 and 5-CQA) drops significantly above $190{ }^{\circ} \mathrm{C}$ since high temperature can promote the degradation of phenolic compounds. Indeed, longer extraction at high temperature favors oxidation and degradation of phenolics. However, degradation products of $\mathrm{n}$-CQA have not been analyzed in this work. This information is crucial, even more since the ratio $n-C Q A / T P C$ is way lower above $190{ }^{\circ} \mathrm{C}\left(\mathrm{n}-\mathrm{CQA} / \mathrm{TPC}=0.070-0.095\right.$ at $110-170{ }^{\circ} \mathrm{C}$, $\mathrm{n}$ CQA/TPC $=0.038$ at $190^{\circ} \mathrm{C}$ ). This suggests that above $190^{\circ} \mathrm{C}$, another source of polyphenols than $n$-CaffeoylQuinic Acid ( $n$ CQA) impacts the result of the Total Polyphenol Content (TPC) and AntiOxidant Capacity (AOC) of the spent coffee grounds (SCG) extract.

Literature about fundamental research has been investigated to understand polyphenols behavior including $\mathrm{n}$ CQA and role of degradation products as new antioxidants in subcritical $\mathrm{H}_{2} \mathrm{O}$. Sato et al. have reported the hydrolysis phenomenon of 3-caffeoylquinic acid into caffeic acid and quinic acid. ${ }^{147}$ Khuwijitjaru et al. have highlighted that caffeic acid has a higher antioxidant capacity $\left(2.37 \mathrm{~g}_{\text {AAEAC. }} \mathrm{g}^{-1}\right.$ caffeic acid $)$ than chlorogenic acid (1.39 $\mathrm{g}_{\text {AAEAC. }} \mathrm{g}^{-1}$ chlorogenic acid $) .{ }^{148}$ Unfortunately, they also have shown that degradation kinetic is faster for caffeic acid than chlorogenic acid. The products resulting from caffeic acid degradation in subcritical water have also been studied (Figure 9). ${ }^{149}$

Chun et al. $\left(220^{\circ} \mathrm{C}, 10 \mathrm{~min}\right)$ and Mussatto et al. $\left(200{ }^{\circ} \mathrm{C}\right.$, $50 \mathrm{~min}$ ) have reported different temperature with different time of extraction under optimal conditions for polyphenols recovery. This suggests that the combination temperature/time of extraction is one of the most important factor to take into account. ${ }^{131}, 150$

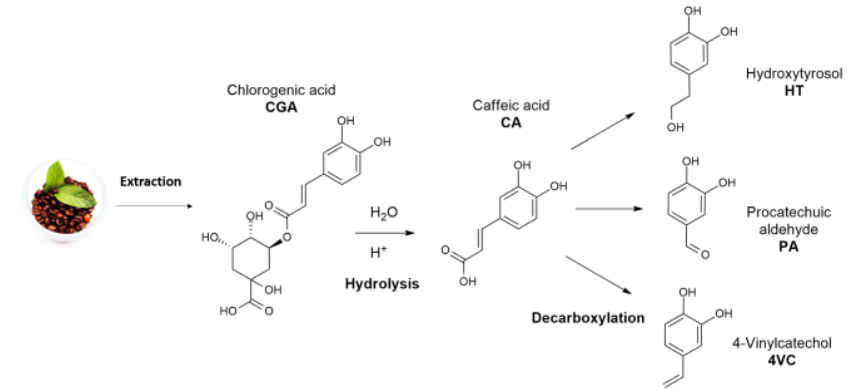

Figure 9: Extraction and degradation mechanism of chlorogenic acid and caffeic acid in subcritical $\mathrm{H}_{2} \mathrm{O}$ adapted from Khuwijitjaru et al. ${ }^{149}$

Inouye et al. have reported the use of subcritical $\mathrm{H}_{2} \mathrm{O}$ for the production of antioxidant extract from coffee silverskin (CSS, Table 4, Entry 9). ${ }^{151}$ They have observed a larger amount of $5-\mathrm{CQA}$ at $80^{\circ} \mathrm{C}\left(1.7 \mathrm{mg} \cdot \mathrm{g}^{-1}\right.$ extract $)$ than at $180^{\circ} \mathrm{C}(1.5 \mathrm{mg} . \mathrm{g}$ $1_{\text {extract }}$ ) and even their absence at $210^{\circ} \mathrm{C}$ (not detected) after $10 \mathrm{~min}$. However, TPC have been reported to inversely increase from $180{ }^{\circ} \mathrm{C}$ (22 mg.g-1 extract) to $210{ }^{\circ} \mathrm{C}$ (36 mg.g 1 extract), contradicting the conclusion with SCG. The authors have supported the hypothesis that hydrolysis or degradation of lignin and lignan generate smaller and soluble phenolic compounds, without further investigations.

Sato et al. have investigated the subcritical $\mathrm{H}_{2} \mathrm{O}$ semicontinuous extraction from green coffee beans at $1 \mathrm{~g} \cdot \mathrm{min}^{-1}$ during 20-60 min (Table 4, Entry 11). ${ }^{147}$ They have reported three different ranges of temperature of extraction: i) 70 to $140{ }^{\circ} \mathrm{C}$ with elevation of Antioxidant Capacity (AOC), ii) 140 to $200{ }^{\circ} \mathrm{C}$ with reduction of $\mathrm{AOC}$ and iii) 200 to $300{ }^{\circ} \mathrm{C}$ with significant raise of $\mathrm{AOC}$. The authors have described that the structural distribution of CaffeoylQuinic Acid (CQA) in natural plants is typically composed of oligomeric structures like glycosides. Hence, in first range $\left(70-140{ }^{\circ} \mathrm{C}\right)$ recover of CQA requires lignocellulose hydrolysis that is enhanced by increasing temperature. For the second range (140-200 $\left.{ }^{\circ} \mathrm{C}\right)$, AntiOxidant Capacity (AOC) and CaffeoylQuinic Acid (CQA) have been reported to decrease simultaneously. The authors have reported that the increase of the temperature leads to the water density decrease and its ionic product increase. Then, the solvation structure and protonation of CaffeoylQuinic Acid (CQA) might be more sensitive resulting in CQA degradation by hydrolysis. Finally, for the third range, AntiOxidant Capacity (AOC) and melanoidins index have been observed to rise simultaneously. Coffee melanoidins have been reported in literature to exhibit antioxidant activity. ${ }^{152}$ Melanoidin is a brown colored high weight heteropolymer that occurs during the Maillard reaction between sugars and amino acids. ${ }^{153}$ The authors have studied the contribution of high molecular weight melanoidins, which is up to $36 \%$ of the total Trolox Equivalent Antioxidant Capacity (TEAC) in coffee brews. Moreover, the authors have pointed out that chlorogenic acids are up to $39 \%$ covalently bounded to melanoidins $\left(220{ }^{\circ} \mathrm{C}, 15 \mathrm{~min}\right)$, which can be partially responsible of the antioxidant activity of melanoidins. ${ }^{153}$

Coimbra et al. have shown that during roasting process the polysaccharides depolymerize then repolymerize, forming new polymers through non-enzymatic 
transglycosylation reactions with phenolic compounds (Figure 10). ${ }^{154}$ In addition, for non-roasted material such as algae biomass, Herrero et al have suggested that Maillard, caramelization and thermoxidation reactions affect the overall antioxidant capacity of subcritical $\mathrm{H}_{2} \mathrm{O}$ extracts depending on the nature of the sample. ${ }^{155}$

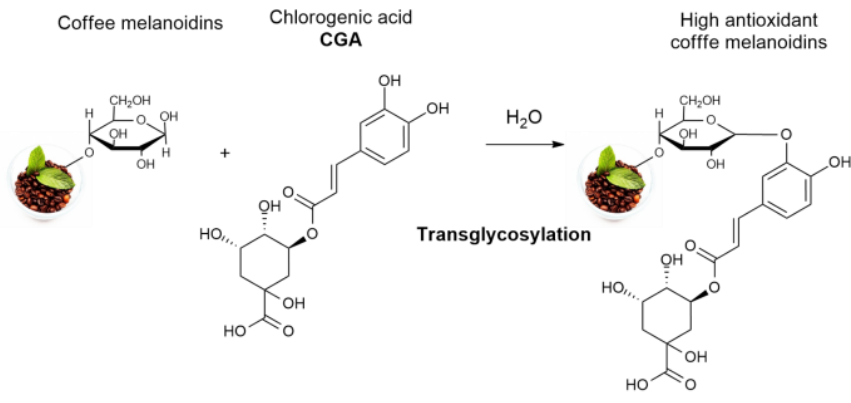

Figure 10: Formation of new antioxidant compounds through transglycosylation of melanoidins with phenolic compounds during roasting step adapted from Coimbra et $a .^{154}$

\subsubsection{Extraction of secondary antioxidant metabolites}

Caffeine, with its antioxidant properties, ${ }^{156}$ is the only molecule from the methylxanthines that is present in large amount in coffee and coffee by-products (Figure 3). Inouye et al. have reported the extraction of caffeine in coffee silverskin with subcritical $\mathrm{H}_{2} \mathrm{O}$ (Table 4, Entry 9). ${ }^{151}$ Caffeine concentration with water extraction at high temperature (270 ${ }^{\circ} \mathrm{C}, 23 \%$ yield, $4.1 \mathrm{mg} \cdot \mathrm{g}^{-1}$ extract) has been proven to be as efficient than ambient water extraction $\left(25{ }^{\circ} \mathrm{C}, 16 \%\right.$ yield, $4.1 \mathrm{mg} . \mathrm{g}$ $1_{\text {extract}}$ ), showing the high thermal and chemical stability of caffeine. ${ }^{151,157}$

Sato et al. have reported the subcritical $\mathrm{H}_{2} \mathrm{O}$ extraction of caffeine in green coffee beans (Table 4, Entry 11). ${ }^{147}$ Caffeine concentration for extraction that have been performed at 280 ${ }^{\circ} \mathrm{C}\left(60 \mathrm{mg} \cdot \mathrm{g}^{-1} \mathrm{GCB}\right)$ are more efficient than at $230{ }^{\circ} \mathrm{C}(18 \mathrm{mg} . \mathrm{g}$ $\left.{ }^{1} \mathrm{GCB}\right)$. The authors have also proposed that higher yield can be correlated to better hydrolysis of cellulosic walls at higher temperature, thus, the trapped caffeine inside the matrix being released. However, these results have to be interpreted carefully since the $60 \mathrm{mg} \cdot \mathrm{g}^{-1} \mathrm{GCB}(6 \% \mathrm{w} / \mathrm{w})$ reported by Sato et al. exceeds the caffeine content value in coffee generally reported in the literature.

Chun et al. have reported results of Total Flavonoid Content (TFC) and catechin, the main flavonoid in coffee and coffee by-products during the extraction of green coffee beans (Table 4, Entry 10). ${ }^{158}$ The authors have obtained better results at $180{ }^{\circ} \mathrm{C}\left(43 \mathrm{mg} \cdot \mathrm{g}^{-1} \mathrm{GCB}\right)$ than $220{ }^{\circ} \mathrm{C}\left(15 \mathrm{mg} \cdot \mathrm{g}^{-1} \mathrm{GCB}\right)$. They have proposed the hypothesis that phenolic compounds and flavonoids have been decomposed in very hot water, with a slower rate of decomposition for flavonoids.

Punbusayakul et al. have investigated anthocyanins extraction $\left(15 \mathrm{~min}, 65-155^{\circ} \mathrm{C}\right.$ ) from coffee pulp by subcritical water acidified with $7 \% \mathrm{v} / \mathrm{v}$ acetic acid (Table 4, Entry 18). ${ }^{159}$ Major anthocyanin in coffee pulp is the cyanidin-3-rutinoside (C-3-R, Figure 3 ). The authors have ascribed that to the dielectric constant of subcritical water at $120^{\circ} \mathrm{C}$ close to those of methanol and ethanol. In addition, it has been reported that anthocyanins have high solubility in methanol. The authors have also suggested that temperature higher than $120^{\circ} \mathrm{C}$ can lead to degradation of the C-3-R linkage.

\subsubsection{Use of non-conventional methods and solvents:}

The subcritical $\mathrm{H}_{2} \mathrm{O}$ has been demonstrated to be an ecocompatible solvent of extraction for biomass valorization. Hence, polyphenols extraction has been compared from subcritical $\mathrm{H}_{2} \mathrm{O}$, non-conventional (ultrasound (US), microwave (MW), Deep Eutectic Solvent (DES), ...) and traditional methods of extraction to evaluate the competitiveness of subcritical $\mathrm{H}_{2} \mathrm{O}$. The following results have to be interpreted with cautious since the raw material of each publication is different and the corresponding conclusions can be slightly biased.

For Ultrasound Assisted Extraction (UAE), Ponmurugan et al. have performed ethanol extraction under different conditions of temperature $\left(30-50{ }^{\circ} \mathrm{C}\right)$, time (5-45 min), liquid/solid ratio (5-30 mL.g ${ }^{-1}$ ) and ultrasonic power output (100-300 W) with TPC range of 32.81-36.23 $\mathrm{mg}_{\mathrm{GAE}} \cdot \mathrm{g}^{-1} \mathrm{SCG}^{160}$ The reported results are higher than traditional one, but no blank under silent conditions has been carried out. Hence, the authors have suggested that during ultrasonic irradiation from 100 to $250 \mathrm{~W}$, the SCG cell is exposed to shock waves and liquid jets, resulting in higher yield. In any case, reported results are still considered as lower than the one of subcritical $\mathrm{H}_{2} \mathrm{O}$. However, UAE can be implemented as pre- or posttreatment of subcritical $\mathrm{H}_{2} \mathrm{O}$ extraction of coffee and coffee by-products, as reported by Chun et al. and Arauzo et al. ${ }^{130,}$ 161

For Microwave Assisted Extraction (MAE), Casazza et al. have conducted hydroalcoholic (EtOH $54 \% \mathrm{v} / \mathrm{v}$ ) extraction under different conditions of temperature (120, 135 and 150 ${ }^{\circ} \mathrm{C}$ ) and heating time (1, 10 and $\left.20 \mathrm{~min}\right) .{ }^{162}$ Highest extraction yield of polyphenols ( $3.9 \mathrm{mg}_{\mathrm{CAE}} \cdot \mathrm{mL}^{-1}$ extract ) have been reported at $150{ }^{\circ} \mathrm{C}$ for $10 \mathrm{~min}$. Those results are two times higher than the blank (room temperature, $24 \mathrm{~h}$ ) with hydroalcoholic

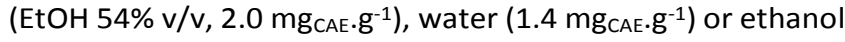
(0.67 $\left.\mathrm{mg}_{\text {CAE }} \cdot \mathrm{g}^{-1}\right)$, despite differences of experimental conditions. The authors have suggested that more intense microwave irradiation power promotes a faster heating with (i) more intense wall-cell rupture and (ii) faster analytes release.

For DES, Lee et al. have tested 13 choline-chloride based DES. ${ }^{163}$ In similar experimental conditions (room temperature, $45 \mathrm{~min}, \mathrm{UAE}$ ), the HeCh DES (15 $\mathrm{mg}_{\mathrm{GAE}} \cdot \mathrm{g}^{-1} \mathrm{SCG}$ ) has showed better TPC results than hydroalcoholic solution (EtOH $\left.20 \% \mathrm{v} / \mathrm{v}, 9 \mathrm{mg}_{\mathrm{GAE}} \cdot \mathrm{g}^{-1}{ }_{\mathrm{SCG}}\right)$ and water $\left(6 \mathrm{mg}_{\mathrm{GAE}} \cdot \mathrm{g}^{-1} \mathrm{sCG}\right)$ used as reference. The authors have observed that the nature of DES is a significant parameter for polyphenols extraction. But no explanation has been proposed to justify the better results observed with HeCh. The authors have also pointed out the necessity of an extra-step with elution column to separate polyphenols from DES. This step has resulted in an optimal polyphenols recovery of $79 \%$.

Globally, subcritical $\mathrm{H}_{2} \mathrm{O}$ has offered higher results for polyphenols recovery than other physical assisted methods of 
extraction. However, the comparison is limited since no reference extraction method has been defined yet. The subcritical $\mathrm{H}_{2} \mathrm{O}$ is the greenest and most competitive solvent reported for the polyphenols extraction of coffee and coffee by-products.

\subsubsection{Biocrude oil and biochar production:}

Biomass can be converted into energy via the production of bio-oil or biocrude oil, a liquid fuel that could replace petroleum. Biocrude oil is obtained via two main methods described in the literature, which are, fast or flash pyrolysis and hydrothermal liquefaction (HTL). Pyrolysis pathway consists in a thermal decomposition without oxygen. Conventional pyrolysis is performed from 280 to $680^{\circ} \mathrm{C}$ at 0.1 $1{ }^{\circ} \mathrm{C}$. $\mathrm{min}^{-1}$. Rapid pyrolysis is performed from 580 to $980{ }^{\circ} \mathrm{C}$ at a $10-200{ }^{\circ} \mathrm{C} . \mathrm{min}^{-1}$ increase of temperature. Flash pyrolysis is performed from 780 to $1030{ }^{\circ} \mathrm{C}$ with ramp $>1000{ }^{\circ} \mathrm{C}$. $\mathrm{min}^{-1} .164$ Flash pyrolysis is the most common method employed at industrial scale. The HTL pathway consists in a reaction between biomass and water at temperatures over $100{ }^{\circ} \mathrm{C} .165$ Hydrochar can be used as solid fuel because of both its higher $\mathrm{HHV}$ and lower volatile matter/ashes ratio than those of raw material. 166

Hydrothermal liquefaction (HTL) is the most suitable method for wet biomass. For this reason, spent coffee grounds with its high moisture content has been studied for the production of biocrude oil and biochar.

$\mathrm{Xu}$ and $\mathrm{He}$ et al. have investigated the influence of retention time (5-25 $\mathrm{min})$, reaction temperature $\left(200-300^{\circ} \mathrm{C}\right)$, water/feedstock mass ratio $\left(5-20 \mathrm{~mL}^{-1}\right)$ and pressure (5-20 bars) during the HTL of spent coffee grounds (Table 4, Entry 19). ${ }^{167}$ Under optimal conditions, the HHV has been

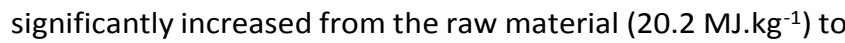
biocrude oil (31.0 MJ. $\left.\mathrm{kg}^{-1}\right)$. To obtained higher yields, a shorter time (10 $\mathrm{min})$ is preferable to a longer time (30 $\mathrm{min}$ ) under the experimental conditions described $\left(300^{\circ} \mathrm{C}, 5 \mathrm{~mL}\right.$.g $\left.{ }^{1}\right) .{ }^{167} \mathrm{Xu}$ and $\mathrm{He}$ et al. have explained that a longer time generates smaller and lighter products and gasesIn addition, solid residues have shown a slight increase after $30 \mathrm{~min}$ that might be caused by the repolymerization of biocrude oil into biochars, reducing then the biocrude oil yield.

In addition, the yield of biocrude oil continuously raises with feedstock/water mass ratio (35.29\% for $5 \mathrm{~mL} . \mathrm{g}^{-1}, 47.28 \%$ for $\left.20 \mathrm{~mL} \cdot \mathrm{g}^{-1}\right) .{ }^{167}$ The authors explained that the lower yields obtained with a lower biomass/solvent ratio are the result of insufficient mixing of reagents. More specifically, these conditions have led to unfavorable heat/mass transfer conditions and to slow down the liquefaction and solvolysis processes, generating less biocrude oil and more solid residues.

Park et al. have characterized a biochar formed during the hydrothermal carbonization (HTC) at different temperatures $\left(180-330{ }^{\circ} \mathrm{C}\right) .{ }^{168}$ The calorific value of raw material $(21.8$ $\left.\mathrm{MJ} . \mathrm{kg}^{-1}\right)$ continuously increases with the temperature from $180{ }^{\circ} \mathrm{C}\left(22.9{\left.\mathrm{MJ} . \mathrm{kg}^{-1}\right)}^{-1}\right.$ to $330^{\circ} \mathrm{C}\left(31.3 \mathrm{MJ}^{\circ} \mathrm{kg}^{-1}\right)$. At contrary, the biochar product yield continuously decreases by increasing the temperature. The authors explained these results by the dehydration and decarboxylation reactions leading to $\mathrm{CO}_{2}$ releases. Hence, the optimal energy yield recovery (ERE) is a compromise between $210^{\circ} \mathrm{C}(94 \%)$ and $240{ }^{\circ} \mathrm{C}(90 \%)$.

No author has experimentally compared inside the same paper the differences between pyrolysis and hydrothermal processes with the same coffee by-product. Hence, Choi et al. have reported the interesting results with an oil yield of $54.85 \%$ obtained after a spent coffee grounds pyrolysis. ${ }^{169}$ Unfortunately, due to high moisture content $(50-60 \% \mathrm{w} / \mathrm{w})$ of spent coffee grounds, a pre-drying step is required to perform the pyrolysis, leading to an important energy consumption limiting the economic viability of the overall process.

As a global conclusion, subcritical $\mathrm{H}_{2} \mathrm{O}$ can act as super solvent, reagent and catalyst able to solubilize, hydrolyze and decarboxylate molecular matrix allowing recovering a wide range of molecules such as low weight carbohydrates and high value polyphenols. Hence, the green subcritical $\mathrm{H}_{2} \mathrm{O}$ can cover almost all the pre-existing applications of coffee and coffee by-products valorization that is typically achieved with traditional solvents or methods. Moreover, subcritical $\mathrm{H}_{2} \mathrm{O}$ is also often more efficient than the physical activation methods of coffee and coffee by-product valorization.

\subsection{Supercritical carbon dioxide $\left(\mathrm{SC}-\mathrm{CO}_{2}\right)$}

Table 5 reports examples involving the use of supercritical carbon dioxide $\left(\mathrm{SC}-\mathrm{CO}_{2}\right)$ for coffee or coffee by-products valorization. This Table 5 does not present the examples from decaffeination process by $\mathrm{SC}-\mathrm{CO}_{2}$ that has been widely investigated and described in several papers and patents. ${ }^{170-}$ 173 Table 5 shows that a wide range of final products is obtained using $\mathrm{SC}-\mathrm{CO}_{2}$ extraction under different experimental conditions, essentially from the extraction or fractionation of the lipophilic fractions. These final products can be classified by field of application: i) bioactive oil extracts including sterols, caffeine, polyphenols for cosmetic industry used in pharmaceutical, cosmetic, nutraceutical or agrifood application; ii) triglycerides oil for biodiesel production.

\subsubsection{Yield of extraction:}

Simões et al. have investigated the influence of pressure (150-300 bars) and temperature $\left(40-55^{\circ} \mathrm{C}\right)$ on the supercritical $\mathrm{CO}_{2}\left(\mathrm{SC}-\mathrm{CO}_{2}\right)$ extraction of spent coffee grounds (Table 5, Entry 3). ${ }^{174} \mathrm{~A}$ maximum $\mathrm{SC}-\mathrm{CO}_{2}$ extraction yield of $85 \%$ has been reached after $3 \mathrm{~h}$ under 250 bars at $50{ }^{\circ} \mathrm{C}$ and 300 bars at $55{ }^{\circ} \mathrm{C}$. Experimental results have pointed out an increase of extraction yield with pressure. According to the authors, the increase of pressure leads to an increase of density of $\mathrm{CO}_{2}$, resulting in higher yield. The extraction curve has also been observed to be splitted in two distinct parts: i) the extraction of available oil at the solid surface and ii) the extraction of oil inside the matrix. Along all this process, extraction rate has been dominated by i) external mass transfer resistance and ii) diffusional and internal mass transfer. In addition, the temperature influence is balanced between two opposite effects. 
CRITICAL REVIEW

Table 4: SCW for coffee and coffee by-products valorization.

\begin{tabular}{|c|c|c|c|c|c|c|}
\hline Entry & Raw material & Parameters & Analysis & Final products & Main results & Ref. \\
\hline 1 & $\begin{array}{l}\text { Spent coffee } \\
\text { grounds }\end{array}$ & $\begin{array}{c}110-190^{\circ} \mathrm{C} \\
50 \text { bars } \\
15-75 \mathrm{~min} \\
10-70 \mathrm{~mL}^{-1} \mathrm{DM}\end{array}$ & $\begin{array}{c}\text { TPC, ABTS, DPPH, HPLC } \\
\text { (CGA) }\end{array}$ & $\begin{array}{l}\text { High antioxidant } \\
\text { extract }\end{array}$ & 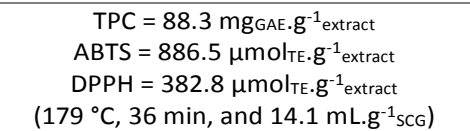 & 112 \\
\hline 2 & $\begin{array}{l}\text { Spent coffee } \\
\text { grounds }\end{array}$ & $\begin{array}{c}180-240{ }^{\circ} \mathrm{C} \\
20-60 \text { bars } \\
10 \mathrm{~min} \\
27 \mathrm{~mL} \cdot \mathrm{g}^{-1} \mathrm{DM} \\
\text { US/MW } \\
\mathrm{N}_{2} / \mathrm{CO}_{2} \text { modifier }\end{array}$ & $\begin{array}{l}\text { TPC, TFC, RSs, proteins, } \\
\text { ABTS, DPPH, MIC }\end{array}$ & $\begin{array}{l}\text { High antioxidant } \\
\text { hydrolysate }\end{array}$ & 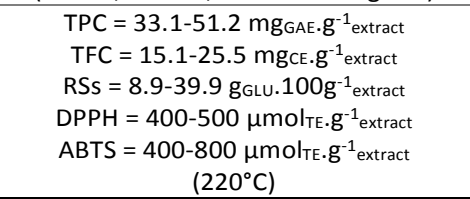 & 131 \\
\hline 3 & $\begin{array}{l}\text { Spent coffee } \\
\text { grounds }\end{array}$ & $\begin{array}{c}120^{\circ} \mathrm{C} \\
20 \mathrm{~min} \\
20 \mathrm{~mL} \cdot \mathrm{g}^{-1} \mathrm{DM} \\
\end{array}$ & TPC, TFC, DPPH, FRAP & $\begin{array}{l}\text { High antioxidant } \\
\text { extract }\end{array}$ & $\begin{array}{c}\mathrm{TPC}=32.9 \mathrm{mgGAE}_{\mathrm{GA}} \mathrm{g}^{-1} \text { extract } \\
\mathrm{TFC}=8.3 \mathrm{mg}_{\mathrm{QE} .} \mathrm{g}^{-1} \text { extract } \\
\mathrm{DPPH}=70 \% \text { inhibition }\end{array}$ & 109 \\
\hline 4 & Coffee silverskin & $\begin{array}{c}120^{\circ} \mathrm{C} \\
20 \mathrm{~min} \\
20 \mathrm{~mL} \cdot \mathrm{g}^{-1} \mathrm{DM} \\
\end{array}$ & TPC, TFC, DPPH, FRAP & $\begin{array}{l}\text { High antioxidant } \\
\text { extract }\end{array}$ & $\begin{array}{c}\text { TPC }=19.2 \mathrm{mg}_{\mathrm{GAE} . \mathrm{g}^{-1} \text { extract }} \\
\mathrm{TFC}=2.7 \mathrm{mgaE} \cdot \mathrm{g}^{-1} \text { extract } \\
\mathrm{DPPH}=60 \% \text { inhibition }\end{array}$ & 109 \\
\hline 5 & $\begin{array}{l}\text { Spent coffee } \\
\text { grounds }\end{array}$ & $\begin{array}{c}\text { Sampled } 140^{\circ} \mathrm{C} \text { then } 220^{\circ} \mathrm{C} \\
\text { (one extraction) } \\
30 \mathrm{~min} \\
3 \mathrm{~g} \\
1 \mathrm{~mL} \cdot \mathrm{min}^{-1} \\
90 \mathrm{~min} \\
\end{array}$ & $\begin{array}{l}\text { TPC, TSC, HPLC, DPPH, } \\
\text { ROS }\end{array}$ & $\begin{array}{l}\text { Bioactive extract (skin } \\
\text { anti-aging) }\end{array}$ & $\begin{array}{c}\text { Yield }=15 \% / 40 \%\left(\text { gextract }_{1} 100 \mathrm{~g}_{\mathrm{SCG}}\right) \\
\mathrm{TPC}=19.9 / 5.7 \mathrm{mg}_{\mathrm{GAE}} \mathrm{g}^{-1} \text { extract } \\
\mathrm{TSC}=3.8 / 28.6\left(\mathrm{~g}_{\mathrm{GLU}} \cdot 100 \mathrm{~g}^{-1} \text { extract }\right) \\
\mathrm{EC}_{50}=20.6 / 132.2 \mu \mathrm{gextract} \mathrm{mL}^{-1}(\mathrm{DPPH}) \\
\left(140 / 220^{\circ} \mathrm{C}\right)\end{array}$ & 110 \\
\hline 6 & $\begin{array}{l}\text { Spent coffee } \\
\text { grounds }\end{array}$ & $\begin{array}{c}80-160^{\circ} \mathrm{C} \\
35-170 \text { bars } \\
5-20 \mathrm{~min} \\
0.5-2.5 \mathrm{~g} \\
25-75 \% \mathrm{EtOH} \\
\% \text { Flush } 20-100 \\
11 \mathrm{~mL} \text { cell } \\
\end{array}$ & $\begin{array}{l}\text { TPC, HPLC (CAF, 5- } \\
\text { CQA), ABTS, DPPH }\end{array}$ & Antioxidant extract & $\begin{array}{c}\mathrm{TPC}=19-26 \mathrm{mg}_{\mathrm{GAE}} \cdot \mathrm{g}^{-1} \mathrm{SCG} \\
\mathrm{EC}_{50}=16-38 \mathrm{mg}_{\mathrm{AAE}} \cdot \mathrm{g}^{-1} \mathrm{~s}^{-1 \mathrm{CG}}(\mathrm{DPPH}) \\
\mathrm{EC}_{50}=10-28 \mathrm{mg}_{\mathrm{AAE}} \cdot \mathrm{g}^{-1} \mathrm{SCG}(\mathrm{ABTS}) \\
\mathrm{CAF}=3.2-9.7 \mathrm{mg} \cdot \mathrm{g}^{-1} \mathrm{sCG} \\
5-\mathrm{CQA}=51-201 \mathrm{mg} \cdot \mathrm{g}^{-1} \mathrm{sCG} \\
\left(195^{\circ} \mathrm{C}, 0.8 \mathrm{~g}\right)\end{array}$ & 113 \\
\hline 7 & $\begin{array}{l}\text { Spent coffee } \\
\text { grounds }\end{array}$ & $\begin{array}{c}60-90^{\circ} \mathrm{C} \\
5-30 \mathrm{~min} \\
0-16 \% \mathrm{EtOH} \\
20 \mathrm{~mL} . \mathrm{g}^{-1} \mathrm{DM} \\
\text { Resin purif } \\
\end{array}$ & $\begin{array}{c}\text { TPC, DPPH, ORAC, } \\
\text { HPLC (HMF) }\end{array}$ & $\begin{array}{c}\text { Polyphenols + } \\
\text { Reduction HMF }\end{array}$ & $\begin{array}{c}\mathrm{TPC}=14 \mathrm{mg}_{\mathrm{GAE}} \cdot \mathrm{g}^{-1} \mathrm{SCG} \\
\mathrm{EC}_{50}=52 \mu \mathrm{mol}_{\mathrm{TE}} \cdot \mathrm{g}^{-1} \mathrm{SCG}(\mathrm{DPPH}) \\
5-\mathrm{CQA}=30 \mu \mathrm{g} \cdot \mathrm{g}^{-1} \mathrm{SCG} \\
\mathrm{HMF} \text { reduction }=95 \% \\
\left(90^{\circ} \mathrm{C}, 16 \% \text { ethanol }\right)\end{array}$ & 175 \\
\hline 8 & $\begin{array}{l}\text { Spent coffee } \\
\text { grounds }\end{array}$ & $\begin{array}{c}160-200^{\circ} \mathrm{C} \\
10-50 \mathrm{~min} \\
5-15 \mathrm{~mL} \cdot \mathrm{g}^{-1} \mathrm{DM}\end{array}$ & $\begin{array}{l}\text { TPC, TFC, TAA, DPPH, } \\
\text { ABTS, FRAP, HPLC } \\
\text { (CGA) }\end{array}$ & Bioactive extract & 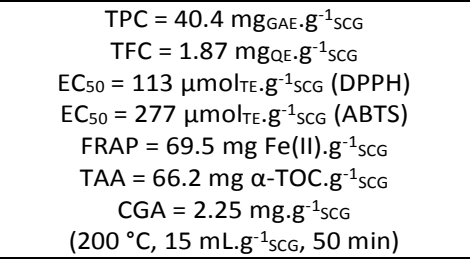 & 150 \\
\hline 9 & Coffee silverskin & $\begin{array}{c}25-80^{\circ} \mathrm{C}\left(\mathrm{H}_{2} \mathrm{O}, 0.1 \mathrm{M} \mathrm{HCl}\right. \\
0.1 \mathrm{M} \mathrm{NaOH})-50 \mathrm{~mL} \cdot \mathrm{g}^{-1} \\
\mathrm{DM} \\
180-270^{\circ} \mathrm{C} \\
10-53 \text { bars } \\
17-42 \mathrm{~min} \\
50 \mathrm{~mL} \cdot \mathrm{g}^{-1} \mathrm{DM}\end{array}$ & $\begin{array}{l}\text { HPLC (CAF, 5-CQA, 5- } \\
\text { HMF), TSC, RSs, } \\
\text { proteins, TPC, DPPH, H- } \\
\text { ORAC }\end{array}$ & $\begin{array}{l}\text { High antioxidant } \\
\text { extract }\end{array}$ & 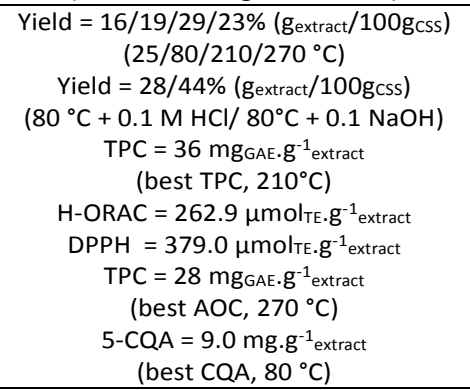 & 151 \\
\hline 10 & Green coffee bean & $\begin{array}{c}180-220^{\circ} \mathrm{C} \\
30-60 \text { bars } \\
10 \mathrm{~min} \\
25 \mathrm{~mL} \cdot \mathrm{g}^{-1} \mathrm{DM} \\
5 \text { types of coffee }\end{array}$ & $\begin{array}{l}\text { TPC, TFC, HPLC (CAF, } \\
\text { CGA), ABTS, DPPH, } \\
\text { MRPs, MIC }\end{array}$ & Bioactive molecules & 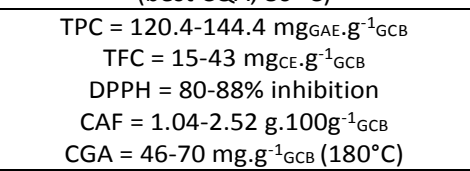 & 158 \\
\hline 11 & Green coffee bean & $\begin{array}{l}50-300^{\circ} \mathrm{C} \\
10-100 \mathrm{bars} \\
20-60 \mathrm{~min}\end{array}$ & $\begin{array}{l}\text { HPLC/UV (CAF, CQA), } \\
\text { UPLC/MS (CQA), DPPH, } \\
\text { TPC, }\end{array}$ & $\begin{array}{l}\text { Bioactive molecules } \\
\text { (degradation 3-CQA) }\end{array}$ & $\begin{array}{c}\mathrm{TPC}=6.7 \mathrm{mg}_{\mathrm{GAE}} \cdot \mathrm{g}^{-1} \mathrm{GCB} \\
\left(157^{\circ} \mathrm{C}, 23 \mathrm{bars}, 60 \mathrm{~min}\right) \\
\mathrm{DPPH}=73.7 \mu \mathrm{mol}_{\mathrm{TE}} \cdot \mathrm{g}^{-1} \mathrm{GCB}\end{array}$ & 147 \\
\hline
\end{tabular}




\begin{tabular}{|c|c|c|c|c|c|c|}
\hline & & $\begin{array}{l}1 \mathrm{~g} \cdot \mathrm{min}^{-1} \\
0.8 \mathrm{~g}\end{array}$ & & & $\begin{array}{c}\left(160^{\circ} \mathrm{C}, 21 \text { bars, } 59 \mathrm{~min}\right. \\
\text { CQAs }=54 \mathrm{mg} \cdot \mathrm{g}^{-1} \mathrm{GCB} \\
\left(212{ }^{\circ} \mathrm{C}, 20 \text { bars, } 55 \mathrm{~min}\right)\end{array}$ & \\
\hline 12 & $\begin{array}{l}\text { Spent coffee } \\
\text { grounds }\end{array}$ & $\begin{array}{l}150-220^{\circ} \mathrm{C} \\
70 \text { bars } \\
30 \mathrm{~min} \\
70 \mathrm{~g} \\
10 \mathrm{~mL} \cdot \mathrm{min}^{-1}\end{array}$ & $\begin{array}{l}\text { TPC, TSC, HPLC, DPPH, } \\
\text { MIC }\end{array}$ & $\begin{array}{l}\text { Antioxidant extract + } \\
\text { carbohydrates }\end{array}$ & $\begin{array}{c}\text { Yield }=55.6 \%\left(\mathrm{~g}_{\text {extract }} / 100 \mathrm{~g}_{\mathrm{sCG}}\right) \\
\mathrm{TPC}=70.3 \mathrm{mg}_{\mathrm{GAE}} \cdot \mathrm{g}^{-1} \text { extract } \\
\mathrm{TSC}=33.7 \mathrm{~g}_{\mathrm{GLU}} \cdot 100 \mathrm{~g}^{-1} \mathrm{sCG} \\
\mathrm{EC}_{50}=1.99 \mathrm{mg}_{\text {extract. }} \mathrm{mg}^{-1} \text { extract }(\mathrm{DPPH}) \\
\mathrm{CGA}=0.7-1.5 \mathrm{mg} \cdot \mathrm{g}^{-1} \mathrm{sCG} \\
\left(200^{\circ} \mathrm{C}\right)\end{array}$ & 133 \\
\hline 13 & $\begin{array}{l}\text { Green coffee } \\
\text { residues }\end{array}$ & $\begin{array}{c}150-250^{\circ} \mathrm{C} \\
225-300 \text { bars } \\
36 \mathrm{~min} \text { (sample every } 2 \\
\mathrm{~min} \text { ) } \\
5 \mathrm{~g} \\
10 \mathrm{~mL}^{-\mathrm{min}^{-1}} \\
\text { Coffee powder Defatted } \\
\text { cake }\end{array}$ & $\begin{array}{l}\text { TPC, TSC, RSs, HPLC } \\
\text { (carbohydrates, 5- } \\
\text { HMF, furfural) }\end{array}$ & $\begin{array}{c}\text { Polyphenols }+ \\
\text { polysaccharides }\end{array}$ & 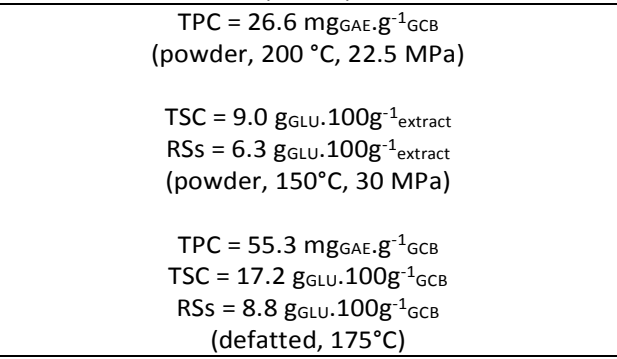 & 176 \\
\hline 14 & $\begin{array}{l}\text { Spent coffee } \\
\text { grounds }\end{array}$ & $\begin{array}{l}150-210{ }^{\circ} \mathrm{C} \\
20-60 \text { bars } \\
5-15 \mathrm{~min} \\
27 \mathrm{~mL} \cdot \mathrm{g}^{-1} \mathrm{DM} \\
\text { US/MW/SC-CO} \\
\text { pretreatment }\end{array}$ & $\begin{array}{c}\text { TPC, TSC, RSs, FT-IR, } \\
\text { TGA, SEM, DPPH, ABTS, } \\
\text { HPLC } \\
\text { (monosaccharides) }\end{array}$ & $\begin{array}{c}\text { Bioactive } \\
\text { polysaccharides }\end{array}$ & 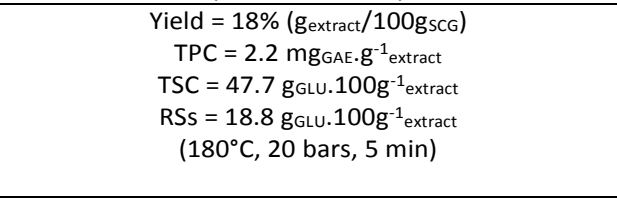 & 130 \\
\hline 15 & $\begin{array}{l}\text { Spent coffee } \\
\text { grounds }\end{array}$ & $\begin{array}{c}160-200^{\circ} \mathrm{C} \\
10-50 \mathrm{~min} \\
5-15 \mathrm{~mL} \cdot \mathrm{g}^{-1} \mathrm{DM}\end{array}$ & $\begin{array}{l}\text { TSC, TPC, RSS, TAA, } \\
\text { DPPH, ABTS, FRAP, } \\
\text { HPLC, XRD, FT-IR }\end{array}$ & $\begin{array}{c}\text { Bioactive } \\
\text { polysaccharides }\end{array}$ & 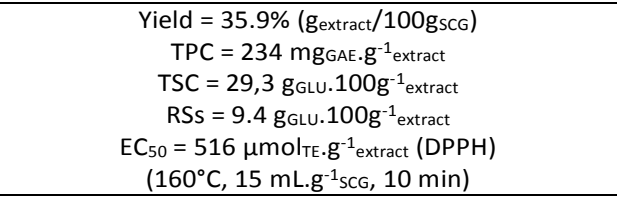 & 111 \\
\hline 16 & $\begin{array}{l}\text { Spent coffee } \\
\text { grounds }\end{array}$ & $\begin{array}{c}100-180{ }^{\circ} \mathrm{C} \\
15-75 \mathrm{~min}^{-} \\
100-140 \mathrm{mg} \mathrm{H}_{2} \mathrm{SO}_{4} \cdot \mathrm{g}^{-1} \\
10-14 \mathrm{~mL} \cdot \mathrm{g}^{-1} \mathrm{DM}\end{array}$ & HPLC & $\begin{array}{c}\text { Bioactive } \\
\text { polysaccharides }\end{array}$ & $\begin{array}{c}\text { Hydrolysis conversion: } \\
\text { Galactan }=100 \% \\
\text { Mannan }=77.4 \% \\
\text { Arabinan }=89.5 \% \\
\text { Hemicellulose }=87.4 \% \\
\end{array}$ & 177 \\
\hline 17 & Green coffee bean & $\begin{array}{c}130-170{ }^{\circ} \mathrm{C} \\
40-90 \mathrm{~min} \\
7-23 \mathrm{~mL} \cdot \mathrm{g}^{-1} \mathrm{DM} \\
0-30 \% \text { EtOH }\end{array}$ & HPLC (CGA) & Chlorogenic acids & $\begin{array}{c}\text { CGA }=50 \mathrm{mg} \cdot \mathrm{g}^{-1} \mathrm{GCB} \\
\left(160^{\circ} \mathrm{C}, 40 \mathrm{~min}, 0 \% \text { eth, } 14 \mathrm{~mL} \cdot \mathrm{g}^{-1}{ }_{\mathrm{GCB}}\right)\end{array}$ & 178 \\
\hline 18 & Coffee pulp & $\begin{array}{l}65-155^{\circ} \mathrm{C} \\
103 \text { bars } \\
15 \text { min }\end{array}$ & HPLC & $\begin{array}{l}\text { Anthocyanin } \\
\text { (C-3-R cyanidin-3- } \\
\text { rutinoside) }\end{array}$ & $\begin{array}{c}\mathrm{C}-3-\mathrm{R}=3 \mathrm{mg} \cdot \mathrm{g}^{-1} \mathrm{CP} \\
\left(120^{\circ} \mathrm{C}\right)\end{array}$ & 159 \\
\hline 19 & $\begin{array}{l}\text { Spent coffee } \\
\text { grounds }\end{array}$ & $\begin{array}{c}200-300{ }^{\circ} \mathrm{C} \\
5-25 \mathrm{~min} \\
5-20 \mathrm{~mL} \cdot \mathrm{g}^{-1} \mathrm{DM} \\
\mathrm{N}_{2}(5-20 \text { bars })\end{array}$ & $\begin{array}{c}\text { GC-MS, FT-IR, } \\
\text { Elemental composition, } \\
\text { HHV }\end{array}$ & Bio-crude oil & $\begin{array}{c}\left.\text { Yield }=47.3 \% \text { (gbio-oil } / 100 \mathrm{~g}_{\mathrm{scG}}\right) \\
\text { Erecovery }=72.6 \% \\
\left.\mathrm{HHV}=31.0 / 20.2 \mathrm{MJ} \cdot \mathrm{kg}^{-1} \text { (biocrude oil } / \text { biochar }\right) \\
\left(275^{\circ} \mathrm{C}, 10 \mathrm{~min}, 20 \mathrm{~mL} . \mathrm{g}^{-1} \mathrm{scG}\right)\end{array}$ & 167 \\
\hline 20 & $\begin{array}{l}\text { Spent coffee } \\
\text { grounds }\end{array}$ & $\begin{array}{c}225-325^{\circ} \mathrm{C} \\
50-100 \text { bars } \\
10 \mathrm{~min} \\
5 \mathrm{~mL} \cdot \mathrm{g}^{-1} \mathrm{DM} \\
5 \% \mathrm{NaOH} \\
\text { Co-liquefaction (PF or CS or } \\
\text { WPB) }\end{array}$ & $\begin{array}{l}\text { GC-MS, GPC, TGA, } \\
\text { viscosity, Elemental } \\
\text { composition, HHV }\end{array}$ & Bio-crude oil & $\begin{array}{c}\text { Yield } \rightarrow+20 \% \text { SCG + CS } \\
\left(250^{\circ} \mathrm{C}, 5 \% \mathrm{NaOH}\right) \\
H H V=40.4 / 31.9 / 29.5 \mathrm{MJ}^{-k g^{-1}} \\
\text { Yield }=20.0 / 25.0 / 29.5 \%\left(\mathrm{~g}_{\text {bio-oi }} / 100 \mathrm{SCG}\right) \\
(\mathrm{SCG} / \mathrm{SCG}+5 \% \mathrm{NaOH} / \mathrm{mix} \text { SCG-CS } 1-1+5 \% \mathrm{NaOH})\end{array}$ & 179 \\
\hline 21 & $\begin{array}{l}\text { Spent coffee } \\
\text { grounds }\end{array}$ & $\begin{array}{c}180-330^{\circ} \mathrm{C} \\
60 \mathrm{~min} \\
1 \mathrm{~mL} \cdot \mathrm{g}^{-1} \mathrm{DM}\end{array}$ & $\begin{array}{c}\text { Elemental composition, } \\
\text { HHV, FT-IR }\end{array}$ & Bio-char & $\begin{array}{c}E_{\text {recovery }} \simeq 95 / 90 / 60 \% \\
H H V=26.5 / 27.5 / 31.3 \mathrm{MJ.kg}^{-1} \\
\text { (biocrude oil, } 210 / 240 / 330^{\circ} \mathrm{C} \text { ) }\end{array}$ & 168 \\
\hline 22 & Coffee husk & $\begin{array}{c}150-225^{\circ} \mathrm{C} \\
20-300 \min \\
1-4 \mathrm{~mL} \cdot \mathrm{g}^{-1} \mathrm{DM}\end{array}$ & $\begin{array}{c}\mathrm{N}_{2} \text { isotherms, } \\
\text { elemental composition, } \\
\text { SEM, FT-IR, TGA, pHzPC, } \\
\text { MB adsorption }\end{array}$ & Hydrochar & $\begin{array}{c}\text { S }_{\text {BET }}=31.3 \mathrm{~m}^{2} \cdot \mathrm{g}^{-1} \text { hydrochar } \\
\text { Methylene blue adorption }=34.9 \mathrm{mg} \cdot \mathrm{g}^{-1} \text { hydrochar } \\
\left(210^{\circ} \mathrm{C}, 243 \mathrm{~min}, 3.41 \mathrm{~mL} \cdot \mathrm{g}^{-1} \mathrm{CH}\right)\end{array}$ & 180 \\
\hline 23 & $\begin{array}{l}\text { Spent coffee } \\
\text { grounds }\end{array}$ & $\begin{array}{c}120-240^{\circ} \mathrm{C} \\
180-720 \mathrm{~min} \\
2-5 \mathrm{~mL} \cdot \mathrm{g}^{-1} \mathrm{DM} \\
\mathrm{H}_{2} \mathrm{O}_{2} \text { adding }\end{array}$ & $\begin{array}{l}\text { (RSM), TGA, } \mathrm{CO}_{2} \\
\text { adsorption }\end{array}$ & $\begin{array}{l}\text { Precursors of } \\
\text { activated carbons }\end{array}$ & $\begin{array}{l}\mathrm{CO}_{2} \text { captured }=2.95 \% \\
\left(180^{\circ} \mathrm{C}-12 \mathrm{~h}\right)\end{array}$ & 181 \\
\hline 24 & $\begin{array}{l}\text { Spent coffee } \\
\text { grounds }\end{array}$ & $\begin{array}{c}163^{\circ} \mathrm{C} \\
45 \mathrm{~min} \\
10 \mathrm{~mL} \cdot \mathrm{g}^{-1} \mathrm{DM} \\
\end{array}$ & $\begin{array}{l}\text { TSC, HPLC, GC (major } \\
\text { and minor volatiles) }\end{array}$ & $\begin{array}{l}1^{\text {rst }} \text { step: extraction } \\
\text { for spirit (drink) }\end{array}$ & $\mathrm{TSC}=3.4 \mathrm{gGLU} \mathrm{L}^{-1}$ & 182 \\
\hline 25 & $\begin{array}{l}\text { Spent coffee } \\
\text { grounds }\end{array}$ & $\begin{array}{c}160-200^{\circ} \mathrm{C} \\
180 \mathrm{~min} \\
8.3-16.7 \mathrm{~mL} \cdot \mathrm{g}^{-1} \mathrm{DM} \mathrm{H} \mathrm{H}_{2} \mathrm{O}\end{array}$ & HPLC-RI, TGA & $\begin{array}{l}\text { Production of levulinic } \\
\text { and formic acid (LA } \\
\text { and FA) }\end{array}$ & $\begin{array}{c}\text { Yield }(\mathrm{w} / \mathrm{w}) \\
\text { LA }=47 \% \\
\mathrm{FA}=29 \% \\
\left(180^{\circ} \mathrm{C}, 8.3 \mathrm{~mL}^{-1} \mathrm{~g}^{-1} \mathrm{SCG}, 3 \mathrm{~h}\right)\end{array}$ & 183 \\
\hline
\end{tabular}


Increasing the temperature decreases the density of the supercritical fluid and thus its solvation capacity. On the other hand, it increases the vapor pressure of the solutes, therefore increasing their solubility in the supercritical solvent.

Mazzafera et al. have explained that the addition of the co-solvent such as isopropyl alcohol and ethanol enhances solvent density and modifies physical and chemical intermolecular interaction forces in the system(Table 5, Entry 15). ${ }^{184}$ More precisely, it increases the local density around the solute molecule, by increasing the physical interactions that are short range forces. In addition, the co-solvent can also lead to hydrogen bonding interaction. ${ }^{185}$ However, since the addition of polar co-solvent targets phenolic and other polar compounds that are usually not extracted during pure $\mathrm{SC}-\mathrm{CO}_{2}$, the measure of oil yield with $\mathrm{SC}-\mathrm{CO}_{2}$ associated to a co-solvent is probably overestimated.

More globally, several parameters such as i) pressure, ii) temperature and iii) co-solvent influence have been pointed out to be the controlled parameters that influence the yield of supercritical $\mathrm{CO}_{2}\left(\mathrm{SC}-\mathrm{CO}_{2}\right)$ extraction. ${ }^{186}$ In particular, pressure is the key parameter to significantly improve extraction yield. In addition, the reported results of yield are often competitive with the one obtained by the use of hexane with Soxhlet. The real challenge for researchers is to obtain the maximum extraction yield with the minimum amount of $\mathrm{CO}_{2}$ used per $\mathrm{g}$ of raw material.

\subsubsection{Fatty Acid Content (FAC) and triglycerides content}

The fatty acid content (FAC) has been investigated for supercritical $\mathrm{CO}_{2}\left(\mathrm{SC}-\mathrm{CO}_{2}\right)$ extraction of coffee and coffee byproducts. Banchero et al. have reported the FAC of spent coffee grounds extract obtained with SC- $\mathrm{CO}_{2}$ (Table 5, Entry 2). ${ }^{187}$ The SC- $\mathrm{CO}_{2}$ extract is composed of 45.0, 23.0, 19.6 and $12.3 \%(\mathrm{w} / \mathrm{w})$ of palmitic (C16:0), linoleic (18:2), stearic (C18:0) and oleic acid (C18:1). The FAC has been demonstrated to be similar in proportion in comparison to the extract obtained with hexane Soxhlet.

Simões et al. have analyzed the Fatty Acid Content (FAC) of $\mathrm{SC}-\mathrm{CO}_{2}$ extract from spent coffee grounds (SCG) at different pressure (150-300 bars) and temperature (40-55 ${ }^{\circ} \mathrm{C}$ ), but no significant difference in FAC has been observed due to these different modifications (Table 5, Entry 3). ${ }^{174}$ More generally, Zaidu et al. have demonstrated that modifying pressure of $\mathrm{SC}-\mathrm{CO}_{2}$ can influence the nature of fatty acids, depending of the number of carbons. Here, the main fatty acids in spent coffee grounds have almost the same number of carbon (C16:0, C18:0, C18:1 and C18:2), making them difficult to be selectively extracted.

In conclusion, the Fatty Acid Content (FAC) is ascribable to raw material nature that shows differences in terms of species origin, cultivation process, location of the coffee plants, etc.

\subsubsection{Bioactive molecules}

\subsubsection{Terpenoids}

Main terpenoids in $\mathrm{SC}-\mathrm{CO}_{2}$ extract of coffee has been observed to be kahweol, cafestol and 16-O-methylcafestol (Figure 5, Table 5, Entries 4, 6, 7, 10 and 11). ${ }^{188-190}$

Acevedo et al. have compared simple, Soxhlet, direct saponification and $\mathrm{SC}-\mathrm{CO}_{2}$ extraction of cafestol (CFT) and kahweol (KW, Table 5, Entry 7). ${ }^{189}$ Best results have been

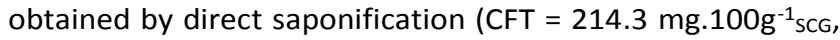
$\mathrm{KW}=466.6 \mathrm{mg} \cdot 100 \mathrm{~g}^{-1} \mathrm{scG}$ ), followed by Soxhlet (CFT = 164.1 $\mathrm{mg} .100 \mathrm{~g}^{-1} \mathrm{scG}, \mathrm{KW}=249.0 \mathrm{mg} \cdot 100 \mathrm{~g}^{-1} \mathrm{scG}$ ), classical $(\mathrm{CFT}=34.4$ $\left.\mathrm{mg} \cdot 100 \mathrm{~g}^{-1} \mathrm{scG}, \mathrm{KW}=42.4 \mathrm{mg} \cdot 100 \mathrm{~g}^{-1} \mathrm{sCG}\right)$ and $\mathrm{SC}-\mathrm{CO}_{2}$ extraction

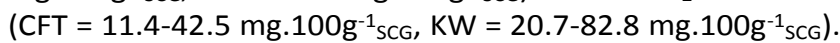
According to the authors, kahweol and cafestol are highly unstable molecules that easily form oxides. Hence, direct saponification has been described in literature as an efficient alternative to extract the unsaponifiable fraction of green coffee beans, avoiding diterpene oxidation. The other procedures (classical, Soxhlet, $\mathrm{SC}-\mathrm{CO}_{2}$ ) produce extracts that are going through a further saponification process after extraction, but exposing diterpenes to a possible higher oxidation rate.

In conclusion, supercritical $\mathrm{CO}_{2}$ is not the most efficient solvent for terpenoids extraction. Hence, supercritical $\mathrm{CO}_{2}$ offers a greater selectivity to produce high value oil enriched in terpenoids.

\subsubsection{Sterols and tocopherols}

Akgün et al. have identified campesterol, stigmasterol, sitosterol, $\alpha$-Tocopherol, $\beta$-tocopherol but also the absence of $\gamma$-tocopherol and $\delta$-tocopherol in the $\mathrm{SC}-\mathrm{CO}_{2}$ extract (Table 5, Entry 8). ${ }^{191}$ The authors, through a response surface methodology (RSM), have estimated that moderate pressures ( $>200$ bars), near-critical temperatures $\left(40^{\circ} \mathrm{C}\right)$ and with long extraction times $(4 \mathrm{~h})$ are required for efficient extraction of sterols and tocopherols. Moreover, they have demonstrated that $\mathrm{SC}-\mathrm{CO}_{2}$ extract is richer in sterols (STR = $\left.12.21-15.60 \%_{\text {oil }}\right)$ and tocopherol (TCPR $=1.51-2.12 \%_{\text {oil }}$ ) with global yield of $10.62-11.41 \%$ compared to hexane Soxhlet (STR $=8.76-8.85 \%$ oil and TCPR $=0.90-2.34 \%_{\text {oil }}$, global yield $=$ 12.29-14.97\%).

More generally, sterols and tocopherols have not been enough investigated to draw accurate conclusions, but SC$\mathrm{CO}_{2}$ has been shown to be efficient and can more selectively extract those compounds compare to hexane Soxhlet.

\subsubsection{Caffeine}

Caffeine identification and quantification have been investigated for supercritical $\mathrm{CO}_{2}\left(\mathrm{SC}-\mathrm{CO}_{2}\right)$ extraction of spent coffee grounds (SCG) and green coffee beans (GCB, Table 5, Entries 5 and 15). ${ }^{184,192}$ Mazzafera et al. have investigated the influence of pressure (152-352 bars), temperature $\left(50-60^{\circ} \mathrm{C}\right)$ and co-solvent (ethanol, isopropyl alcohol) on the $\mathrm{SC}-\mathrm{CO}_{2}$ 
extraction of caffeine in GCB (Table 5, Entry 15). ${ }^{184}$ The most efficient $\mathrm{SC}-\mathrm{CO}_{2}$ extraction (17 $\mathrm{g}_{\text {caffeine. }} \mathrm{g}^{-1}$ solvent $)$ has been reported to be the combination of high pressure (352 bars) and the addition of a co-solvent (EtOH $5 \% \mathrm{w} / \mathrm{w})$. Without the co-solvent, the yield is ten times lower $\left(1.7 \mathrm{~g}_{\text {caffeine }} \cdot \mathrm{g}^{-1}\right.$ solvent $)$. According to the authors, that might be due to caffeine molecules in GCB that are complexed by chlorogenic acids, and then hydrogen bonds between caffeine and chlorogenic acid molecules have to be broken. The addition of EtOH allows the solvation of caffeine and intermolecular interaction between $\mathrm{EtOH}$ and caffeine such as hydrogen bonding, resulting in higher yield.

In conclusion, contrary to one might think due to supercritical $\mathrm{CO}_{2}$ decaffeination, $\mathrm{SC}-\mathrm{CO}_{2}$ is not the most appropriate solvent to remove caffeine. Hence, it is the most suitable solution to enrich selectively coffee oil in caffeine.

\subsubsection{Polyphenols}

Polyphenols and antioxidant activity have been investigated for supercritical $\mathrm{CO}_{2}\left(\mathrm{SC}-\mathrm{CO}_{2}\right)$ extraction of spent coffee grounds (SCG, Table 5, Entry 25). ${ }^{193}$ Coelho et al. have performed 2,2-diphenyl-1-picrylhydrazyl (DPPH) analysis of SCG extract obtained by $\mathrm{SC}-\mathrm{CO}_{2}$ extraction at different pressure (300-400 bars), temperature $\left(40-60{ }^{\circ} \mathrm{C}\right)$ and cosolvent (EtOH). ${ }^{194}$ The most antioxidant extract (Inhibition Concentration $\mathrm{IC}_{50}=12.39 \mathrm{mg}$ extract $\left.\cdot \mathrm{mL}^{-1} \mathrm{DPPH}\right)$ has been observed at 300 bars, $60{ }^{\circ} \mathrm{C}$ with $10 \% \mathrm{EtOH}$. The SC- $\mathrm{CO}_{2}$ extractions without EtOH $\left(\mathrm{IC}_{50}=96.23-163.1 \mathrm{mg}\right.$ extract $\cdot \mathrm{mL}^{-}$ $\left.1_{\mathrm{DPPH}}\right)$ have been reported to be four to six times less efficient than hexane Soxhlet $\left(\mathrm{IC}_{50}=25.07 \mathrm{mg}\right.$ extract $\left.\cdot \mathrm{mL}^{-1} \mathrm{DPPH}\right)$. Hence, co-solvent is the most influent parameter compared to pressure and temperature, during a $\mathrm{SC}-\mathrm{CO}_{2}$ extraction of antioxidants molecules. According to the authors, the addition of $\mathrm{EtOH}$ is necessary to increase the solvent polarity that is essential for extraction of polar molecules, responsible for the antioxidant capacity.

In conclusion, $\mathrm{SC}_{-} \mathrm{CO}_{2}$ is not suitable solvent for polyphenols extraction. Hence, the addition of EtOH cosolvent is an interesting opportunity for enrichment of oil in polyphenols.

To conclude, $\mathrm{SC}-\mathrm{CO}_{2}$ and $\mathrm{SC}-\mathrm{CO}_{2} / \mathrm{EtOH}$ are not the most efficient solvents for bioactive molecules recovery in term of quantity, but are more selective than hexane Soxhlet. It is possible to obtain dual enrichment into lipophilic and hydrophilic compounds, by performing sequential extraction with pure $\mathrm{SC}-\mathrm{CO}_{2}$ followed by $\mathrm{SC}-\mathrm{CO}_{2} / \mathrm{EtOH}$ extraction, both at low pressure.

\subsubsection{Fractionation}

Fractionation with $\mathrm{SC}-\mathrm{CO}_{2}$ is a more rarely investigated step for the valorization of coffee and coffee by-products. This is mainly due to the necessity for the operators to possess a supercritical system with at least two or more separators. Hence, it represents another alternative to i) enrich an extract selectively in specific compounds or ii) to completely recover expected compounds or removing unwanted compounds as described in by Reverchon et al. ${ }^{195}$

Bitencourt et al. have reported the use of supercritical $\mathrm{CO}_{2} / \mathrm{EtOH} \quad\left(\mathrm{SC}-\mathrm{CO}_{2} / \mathrm{EtOH}, \quad 90.6 / 9.4 \mathrm{w} / \mathrm{w}\right)$ followed by fractionation into 4 separators (Table 5, Entry 4). ${ }^{196}$ Pressurization of the separators have been performed with SC- $\mathrm{CO}_{2} / \mathrm{EtOH}(90.6 / 9.4 \mathrm{w} / \mathrm{w}$, condition A) and with pure SC$\mathrm{CO}_{2}$ (condition $\mathrm{B}$ ) at $300,200,100$ bars and $\mathrm{P}_{\mathrm{atm}}$, respectively called F1, F2, F3 and F4 (Figure 11). Results have shown that nearly the entire extract precipitates in $\mathrm{F} 3$ and $\mathrm{F} 4$. According to the authors, the spent coffee grounds (SCG) extract is mainly composed of a lipid portion that is highly soluble in SC$\mathrm{CO}_{2} / \mathrm{EtOH}$, even at 300 and 200 bars. More specifically, the extract precipitation in separators $\mathrm{F} 3$ and $\mathrm{F} 4$ can also be explained by the observations of phase equilibrium behavior for $\mathrm{CO}_{2} / \mathrm{EtOH}$ system. Under condition $\mathrm{A}$, the Total polyphenol content (TPC) of the extract obtained from F1 (TPC $3.2=\mathrm{mg}_{\mathrm{GAE}} \cdot \mathrm{g}^{-1}$ extract $)$ is four times more concentrated than the original $\mathrm{SC}-\mathrm{CO}_{2} / \mathrm{EtOH}$ extract without fractionation

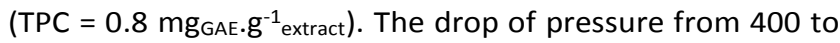
300 bars induces a more selective precipitation of polyphenols than other compounds. Yet, the results have to be interpreted with cautious; the F1 extract is the most enriched in polyphenols but is not the fraction with the largest amount of polyphenols, representing only $9.55 \%$ of the polyphenols extracted from SCG (for examples, $\mathrm{TPC}_{\mathrm{SCG}}=$

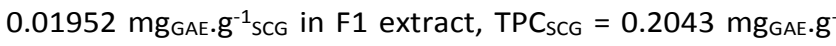
${ }^{1}{ }_{S C G}$ in total extract). Under condition $B$, the use of pure SC$\mathrm{CO}_{2}$ to pressurize the separators have been performed to reduce drastically the EtOH concentration, thus, decreasing polarity of solvent to expect a higher polyphenols precipitation in F1. The TPC measured in F1, condition B (TPC $=3.4 \mathrm{mg}_{\mathrm{GAE}} \cdot \mathrm{g}^{-1}$ extract $)$ is slightly better than the one in $\mathrm{F} 1$, condition A (TPC $=3.2 \mathrm{mg}_{\mathrm{GAE}} \cdot \mathrm{g}^{-1}$ extract), but the improvement is not significant and is in the uncertainties interval. By the way, a more significant precipitation of extract has been reported under F3 (100 bars) of condition B (yield $=13.6 \%$ ) than F3 under condition A (yield $=8.6 \%$ ). According to the authors, this might be due to the decrease of ethanol content in the solvent mixture (condition B) that significantly decreases the solubility of coffee lipids and phenolic compounds at 100 bars.

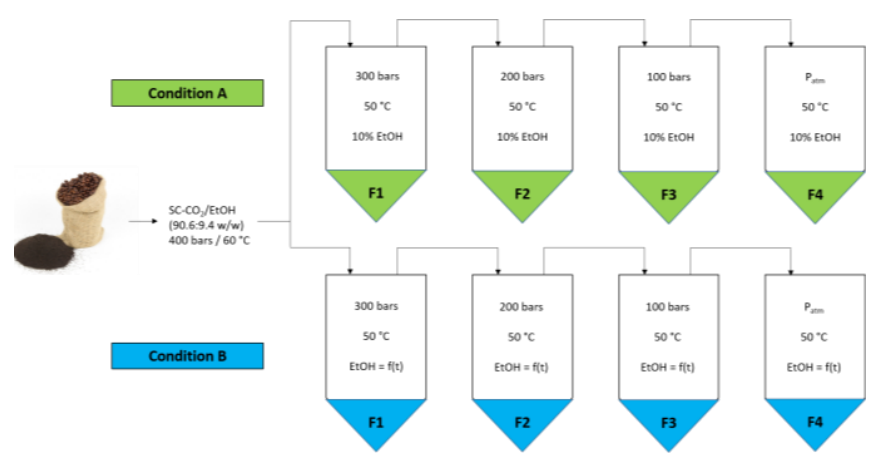

Figure 11: Fractionation process of SC- $\mathrm{CO}_{2}$ extraction of SCG for production of extracts enriched in phenolic compounds, adapted from Bitencourt et al. ${ }^{196}$ 


\section{CRITICAL REVIEW}

\begin{tabular}{|c|c|c|c|c|c|c|}
\hline Entry & $\begin{array}{c}\text { Raw } \\
\text { material }\end{array}$ & Parameters & Analysis & Final products & Main results & Ref. \\
\hline 1 & $\begin{array}{l}\text { Spent coffee } \\
\text { grounds }\end{array}$ & $\begin{array}{c}40-55^{\circ} \mathrm{C} \\
190 \mathrm{bars} \\
0-450 \mathrm{~min} \\
60 \mathrm{~g} \\
12 \mathrm{~g} \cdot \mathrm{min}^{-1}\end{array}$ & GC-FID (FAC) & Lipids & $\begin{array}{c}\text { AbsYield }=11.5 \% \\
\text { RelYield }=75 \% \\
\left.\text { (190 bars, } 40^{\circ} \mathrm{C}, 400 \mathrm{~min}\right) \\
\text { FAC: } \\
\text { C18:2 } \rightarrow 44.5 \% \\
\text { C16:0 } \rightarrow 37.5 \%\end{array}$ & 197 \\
\hline 2 & $\begin{array}{l}\text { Spent coffee } \\
\text { grounds }\end{array}$ & $\begin{array}{c}40-60^{\circ} \mathrm{C} \\
350-500 \text { bars } \\
0-500 \mathrm{~min} \\
16 \mathrm{~g} \\
1 \mathrm{~g} \cdot \mathrm{min}^{-1}\end{array}$ & GC (FAC) & Lipids & $\begin{array}{c}\text { AbsYield }=4.8 \% \\
\text { RelYield }=85 \% \\
\left(500 \text { bars, } 60^{\circ} \mathrm{C}, 350 \mathrm{~min}\right)\end{array}$ & 187 \\
\hline 3 & $\begin{array}{l}\text { Spent coffee } \\
\text { grounds }\end{array}$ & $\begin{array}{c}40-60^{\circ} \mathrm{C} \\
150-300 \text { bars } \\
180 \mathrm{~min} \text { (sample each } \\
15 \mathrm{~min} \mathrm{x} 4+60 \mathrm{~min} \mathrm{x} \\
2 \text { ) } \\
20 \mathrm{~g} \\
10 \mathrm{~g} \cdot \mathrm{min}^{-1} \mathrm{CO}_{2} \\
0.7 \mathrm{~g} \cdot \mathrm{min}^{-1} \mathrm{EtOH} \\
\end{array}$ & $\mathrm{GC}(\mathrm{FAC})$ & Lipids & $\begin{array}{c}\text { AbsYield }=15.4 \%\left(55^{\circ} \mathrm{C}, 300 \text { bars }\right) \\
\text { AbsYield }=19.4 \%\left(40^{\circ} \mathrm{C}, 200 \text { bars, EtOH }\right) \\
\text { FAC: } \\
\text { C18:2 } \rightarrow 35 \% \\
\text { C16:0 } \rightarrow 35 \%\end{array}$ & 174 \\
\hline 4 & $\begin{array}{l}\text { Spent coffee } \\
\text { grounds }\end{array}$ & $\begin{array}{c}40-70{ }^{\circ} \mathrm{C} \\
140-190 \text { bars } \\
60 \mathrm{~g} \\
12 \mathrm{~g} \cdot \mathrm{min}^{-1} \\
0-5 \% \mathrm{EtOH}\end{array}$ & $\begin{array}{l}\text { HPLC-UV (kahweol, } \\
\text { cafestol, 16-O- } \\
\text { Methylcafestol), }\end{array}$ & $\begin{array}{c}\text { Lipids }+ \\
\text { Terpenoids }\end{array}$ & $\begin{array}{c}\text { AbsYield }=12.0 \% \\
\left(55^{\circ} \mathrm{C}, 190 \text { bars, } 5 \% \text { EtOH }\right) \\
\text { Terpenes }=107.4{\mathrm{mg} . \mathrm{g}^{-1}} \\
\left(55^{\circ} \mathrm{C}, 140 \text { bars, } \% \text { EtOH }\right)\end{array}$ & 188 \\
\hline 5 & $\begin{array}{l}\text { Spent coffee } \\
\text { grounds }\end{array}$ & $\begin{array}{c}40-80^{\circ} \mathrm{C} \\
100-200 \text { bars } \\
0-300 \mathrm{~min} \\
\text { Static extraction (10- } \\
90 \mathrm{~min}) \\
\text { Dynamic } 2.0 \mathrm{~mL} \mathrm{~min}^{-1} \\
\text { EtOH/SCG }(0.25 / 1 \text { to } \\
2 / 1)\end{array}$ & $\begin{array}{l}\text { GC (FAC), IV, SV, } \\
\text { TPC, ABTS, DPPH, } \\
\text { polyphenols, CAF }\end{array}$ & $\begin{array}{l}\text { Lipids + } \\
\text { Polyphenols }\end{array}$ & 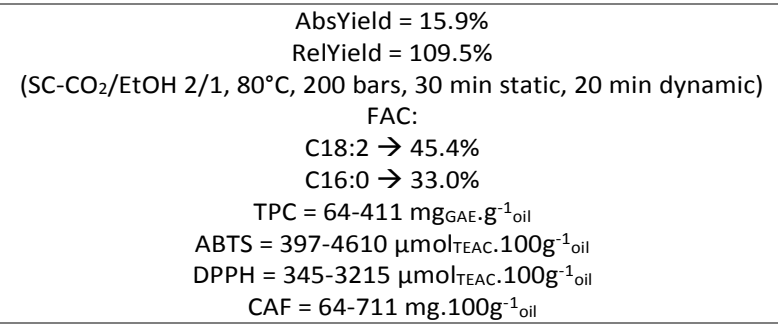 & 192 \\
\hline 6 & $\begin{array}{l}\text { Spent coffee } \\
\text { grounds }\end{array}$ & $\begin{array}{c}40-60^{\circ} \mathrm{C} \\
300-400 \text { bars } \\
0-220 \mathrm{~min} \\
15 \mathrm{~g} \\
1.8 \mathrm{~g} \cdot \mathrm{min}^{-1} \\
0-10 \% \mathrm{EtOH}\end{array}$ & $\begin{array}{l}\text { DPPH, }{ }^{1} \mathrm{H} \text { NMR, } \\
\text { terpenes }\end{array}$ & Lipids & 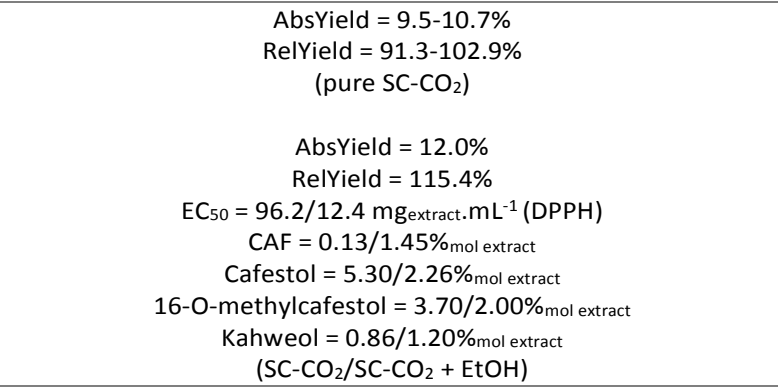 & 194 \\
\hline 7 & $\begin{array}{l}\text { Spent coffee } \\
\text { grounds }\end{array}$ & $\begin{array}{c}40-80^{\circ} \mathrm{C} \\
98-379 \text { bars } \\
60 \mathrm{~min} \\
12 \mathrm{~g}\end{array}$ & $\begin{array}{c}\text { GC (FAC), OSI, PV, } \\
\text { HPLC (kahweol, } \\
\text { cafestol), LC-MS-MS } \\
\text { (polyphenols), TPC, } \\
\text { DPPH }\end{array}$ & $\begin{array}{c}\text { Lipids + } \\
\text { polyphenols }\end{array}$ & 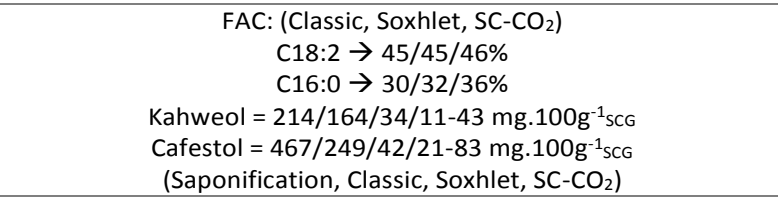 & 189 \\
\hline 8 & $\begin{array}{l}\text { Spent coffee } \\
\text { grounds }\end{array}$ & $\begin{array}{c}33-67^{\circ} \mathrm{C} \\
116-284 \text { bars } \\
19-221 \text { min } \\
24 \mathrm{~mL} \cdot \mathrm{min}^{-1}\end{array}$ & $\begin{array}{l}\text { GC (FAC, sterols, } \\
\text { tocopherols) }\end{array}$ & $\begin{array}{l}\text { Lipids + sterols + } \\
\text { tocopherols }\end{array}$ & $\begin{array}{c}\text { FAC: }\left(\text { Soxhlet } / \mathrm{SC}^{\left.-\mathrm{CO}_{2}\right)}\right. \\
\text { C18:2 }=24.5 / 27.2 \% \\
\text { C16:0 }=48.4 / 49.0 \% \\
\text { Tocopherols SCG1 }=0.90 / 1.51 \% \text { oil } \\
\text { Tocopherols SCG2 }=2.34 / 2.12 \%_{\text {oil }} \\
\text { Sterols SCG1 }=8.85 / 12.21 \% \%_{\text {oil }} \\
\text { Sterols SCG2 }=8.76 / 15.60 \% \text { oil }\end{array}$ & 191 \\
\hline
\end{tabular}




\begin{tabular}{|c|c|c|c|c|c|c|}
\hline 9 & $\begin{array}{l}\text { Spent coffee } \\
\text { grounds }\end{array}$ & $\begin{array}{c}200-300^{\circ} \mathrm{C} \\
100-200 \text { bars } \\
40-50 \mathrm{~min} \\
\mathrm{CO}_{2} / \mathrm{MeOH}=0.11-0.30 \\
\text { (mol/mol) } \\
\text { In-situ } \\
\text { transesterification }\end{array}$ & GC (FAC, FAME) & Lipids (biodiesel) & $\begin{array}{c}\text { FAME Yield }=84.9 \% \\
\left(330^{\circ} \mathrm{C}, 300 \text { bars, } \mathrm{SC}-\mathrm{MeOH}\right) \\
\text { FAME Yield }=93.4 \% \\
\left(300^{\circ} \mathrm{C}, 100 \text { bars, } \mathrm{SC}-\mathrm{CO}_{2} / \mathrm{MeOH}=0.11 \mathrm{~mol} / \mathrm{mol}\right)\end{array}$ & 198 \\
\hline 10 & $\begin{array}{l}\text { Green coffee } \\
\text { bean }\end{array}$ & $\begin{array}{c}60-90^{\circ} \mathrm{C} \\
235-380 \text { bars } \\
25 \mathrm{~min} \\
0.2 \mathrm{~g} \\
1.5 \mathrm{~mL} \cdot \mathrm{min}^{-1}\end{array}$ & $\begin{array}{l}\text { HPLC (kahweol, } \\
\text { cafestol) }\end{array}$ & $\begin{array}{l}\text { Lipids }+ \\
\text { Terpenoids }\end{array}$ & 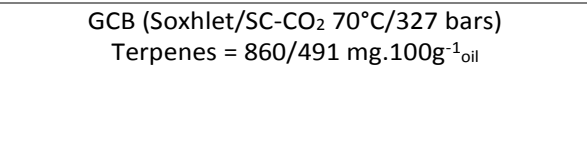 & 190 \\
\hline 11 & $\begin{array}{l}\text { Roasted coffee } \\
\text { bean }\end{array}$ & $\begin{array}{l}60-90^{\circ} \mathrm{C} \\
235-380 \text { bars } \\
25 \mathrm{~min} \\
0.2 \mathrm{~g} \\
1.5 \mathrm{~mL} \cdot \mathrm{min}^{-1}\end{array}$ & $\begin{array}{l}\text { HPLC (kahweol, } \\
\text { cafestol) }\end{array}$ & $\begin{array}{l}\text { Lipids }+ \\
\text { Terpenoids }\end{array}$ & 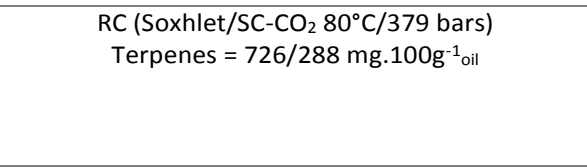 & 190 \\
\hline 12 & $\begin{array}{l}\text { Spent coffee } \\
\text { grounds }\end{array}$ & $\begin{array}{c}40-60{ }^{\circ} \mathrm{C} \\
100 \mathrm{bars} \\
150 \mathrm{~min} \\
15 \mathrm{~g} \\
6.6-16.6 \mathrm{~g} \cdot \mathrm{min}^{-1} \mathrm{SC}-\mathrm{CO}_{2} \\
4-15 \% \mathrm{EtOH}\end{array}$ & $\begin{array}{l}\text { DPPH, ABTS, TPC, } \\
\text { HPLC (polyphenols) }\end{array}$ & $\begin{array}{l}\text { High antioxidant } \\
\text { extract }\end{array}$ & 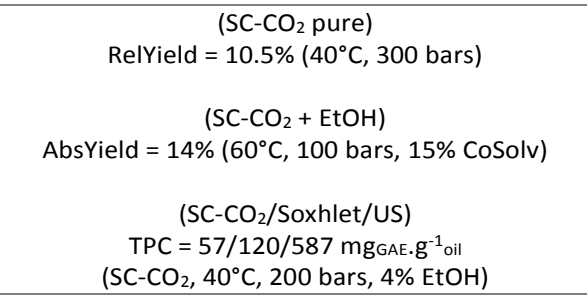 & 199 \\
\hline 13 & Coffee husk & 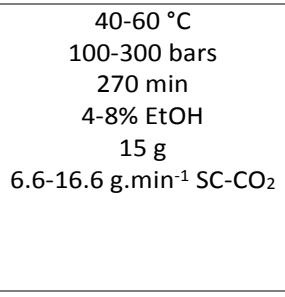 & $\begin{array}{l}\text { DPPH, ABTS, TPC, } \\
\text { HPLC (polyphenols) }\end{array}$ & $\begin{array}{l}\text { High antioxidant } \\
\text { extract }\end{array}$ & 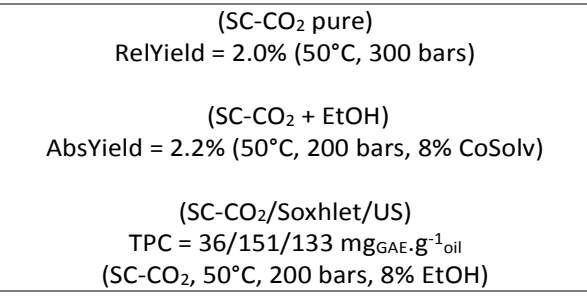 & 199 \\
\hline 14 & $\begin{array}{l}\text { Green coffee } \\
\text { bean }\end{array}$ & $\begin{array}{c}50-70^{\circ} \mathrm{C} \\
152-352 \text { bars } \\
100 \mathrm{~min} \\
15 \mathrm{~g} \\
1.8 \mathrm{~g} \cdot \mathrm{min}^{-1}\end{array}$ & HPLC (FAC, CAF) & Lipids + CAF & $\begin{array}{c}\text { AbsYield }=15.1 \% \\
\text { YieldCAF }=92.2 \% \\
\left(\mathrm{SC}_{-}-\mathrm{CO}_{2}, 152 \text { bars, } 70^{\circ} \mathrm{C}\right)\end{array}$ & 200 \\
\hline 15 & $\begin{array}{l}\text { Green coffee } \\
\text { bean }\end{array}$ & $\begin{array}{c}50-60^{\circ} \mathrm{C} \\
152-352 \text { bars } \\
15 \mathrm{~g} \\
1.8 \mathrm{~g} \cdot \mathrm{min}^{-1} \\
\text { Pure or } 5 \% \text { IPA or EtOH }\end{array}$ & $\operatorname{HPLC}(C A F, C G A)$ & $\begin{array}{l}\text { Lipids + CAF + } \\
\quad \text { CGA }\end{array}$ & $\begin{array}{c}\text { SC- } \mathrm{CO}_{2}+\text { None } / \mathrm{IPA} / \text { EtOH } \\
\text { RelYield }=70 / 93 / 99 \% \\
\mathrm{CAF}=1.7 / 2 / 17 \mathrm{~g} \cdot 100 \mathrm{~g}^{-1} \text { oil of solvent } \\
\mathrm{CGA}=0 / \text { traces } / 0 \\
\left(60^{\circ} \mathrm{C}, 352 \text { bars }\right)\end{array}$ & 184 \\
\hline 16 & $\begin{array}{l}\text { Green coffee } \\
\text { bean }\end{array}$ & $\begin{array}{c}40-60^{\circ} \mathrm{C} \\
150-300 \text { bars } \\
360 \mathrm{~min} \\
4-25 \mathrm{~g} \\
3-5 \mathrm{~mL} \cdot \mathrm{min}^{-1} \mathrm{CO}_{2} \\
1 \mathrm{~mL} \cdot \mathrm{min}^{-1} \mathrm{H}_{2} \mathrm{O}\end{array}$ & HPLC (CAF, CLA) & $\mathrm{CAF}+\mathrm{CGA}$ & Most influent: pressure & 201 \\
\hline 17 & Coffee husk & $\begin{array}{l}40-100^{\circ} \mathrm{C} \\
60-300 \text { bars } \\
100-300 \mathrm{~min} \\
\text { Humidity }\end{array}$ & HPLC (CAF) & CAF & $\begin{array}{c}\mathrm{CAF}=84 \%\left(197 \mathrm{~g} \mathrm{CO}_{2} \cdot \mathrm{g}^{-1} \mathrm{CH}\right) \\
\mathrm{CAF}=78 \%\left(58 \mathrm{~g} \mathrm{CO}_{2} \cdot \mathrm{g}^{-1} \mathrm{CH}\right) \\
\left(\mathrm{SC}^{-1} \mathrm{CO}_{2}, 100{ }^{\circ} \mathrm{C}, 300 \text { bars, } 32 \% \text { humidity }\right)\end{array}$ & 202 \\
\hline 18 & $\begin{array}{l}\text { Spent coffee } \\
\text { grounds }\end{array}$ & $\begin{array}{c}50^{\circ} \mathrm{C} \\
250 \mathrm{bars} \\
180 \mathrm{~min} \\
1.9-5.3 \mathrm{~g} \cdot \mathrm{min}^{-1}\end{array}$ & FAC, MDTC & Lipids (PHA) & $\begin{array}{c}\text { RelYield }=90 \% \\
\text { AbsYield }=12.6 \% \\
\text { FAC: } \\
\text { C18:2 } \rightarrow 38.4 \% \\
\text { C16:2 } \rightarrow 39.7 \%\end{array}$ & 203 \\
\hline 19 & $\begin{array}{l}\text { Spent coffee } \\
\text { grounds }\end{array}$ & 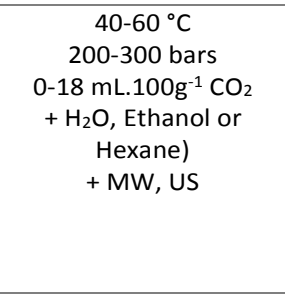 & GC (FAC) & Lipids & $\begin{array}{c}\text { AbsYield }=15.1 \% \\
\text { RelYield }=90.6 \% \\
\left(60^{\circ} \mathrm{C}, 300 \text { bars }\right) \\
\text { AbsYield }=16.4 \% \\
\text { RelYield }=98.1 \% \\
\left(40^{\circ} \mathrm{C}, 250 \text { bars, } 18 \mathrm{~mL} \text { EtOH }\right) \\
\text { FAC: } \\
\text { C18:2 } \rightarrow 25.8-44.1 \% \\
\text { C16:0 } \rightarrow 33.6-36.9 \%\end{array}$ & 204 \\
\hline 20 & $\begin{array}{l}\text { Spent coffee } \\
\text { grounds }\end{array}$ & $\begin{array}{l}55^{\circ} \mathrm{C} \\
250 \text { bars } \\
60 \mathrm{~min}\end{array}$ & FFA, UPL, GC (FAC) & Lipids (cosmetic) & $\begin{array}{c}\text { AbsYield }=12.1 \% \\
\text { FAC: } \\
\text { C18:2 }=44.7 \%\end{array}$ & 205 \\
\hline
\end{tabular}




\begin{tabular}{|c|c|c|c|c|c|c|}
\hline & & $\begin{array}{c}500 \mathrm{~g} \\
4.2 \mathrm{~g} \cdot \mathrm{min}^{-1}\end{array}$ & & & $\mathrm{C} 16: 0=33.1 \%$ & \\
\hline 21 & $\begin{array}{l}\text { Spent coffee } \\
\text { grounds }\end{array}$ & $\begin{array}{c}50^{\circ} \mathrm{C} \\
200 \text { bars } \\
120 \mathrm{~min} \\
45 \mathrm{~mL}^{-\mathrm{min}^{-1}} \\
1000 \mathrm{~g} \\
10 \% \mathrm{EtOH}\end{array}$ & $\begin{array}{c}\text { GC (FAC), biological } \\
\text { assays }\end{array}$ & $\begin{array}{l}\text { High value } \\
\text { extract }\end{array}$ & $\begin{array}{c}\text { FAC: } \\
\text { C18:2 } \rightarrow 43.3 \% \\
\text { C16:0 } \rightarrow 35.2 \%\end{array}$ & 206 \\
\hline 22 & $\begin{array}{l}\text { Spent coffee } \\
\text { grounds }\end{array}$ & $\begin{array}{c}40-60^{\circ} \mathrm{C} \\
175-250 \text { bars } \\
60-300 \mathrm{~min} \\
1500 \mathrm{~g} \\
1833-2833 \mathrm{~mL} \cdot \mathrm{min}^{-1}\end{array}$ & $\begin{array}{l}\text { GC (FAC), FFA, AV, } \\
\text { IV, PV, TBARS }\end{array}$ & Lipids & $\begin{array}{c}\text { AbsYield }=12.1 \% \\
\text { RelYield }=79 \% \\
\left(50^{\circ} \mathrm{C}, 200 \text { bars, } 120 \mathrm{~min}\right) \\
\text { FAC: } \\
\text { C18:2 } \rightarrow \text { 35-43\% } \\
\text { C16:0 } \rightarrow 33-42 \%\end{array}$ & 207 \\
\hline 23 & $\begin{array}{l}\text { Green coffee } \\
\text { bean }\end{array}$ & $\begin{array}{c}66-94^{\circ} \mathrm{C} \\
179-325 \text { bars } \\
20 \text { min static } \\
360 \text { min dynamic } \\
5 \mathrm{~g} \cdot \mathrm{min}^{-1}\end{array}$ & $\begin{array}{l}\text { GC-MS (terpenoids, } \\
\text { CAF, FAC), TPC }\end{array}$ & $\begin{array}{l}\text { Lipids, } \\
\text { Terpenoids, CAF }\end{array}$ & 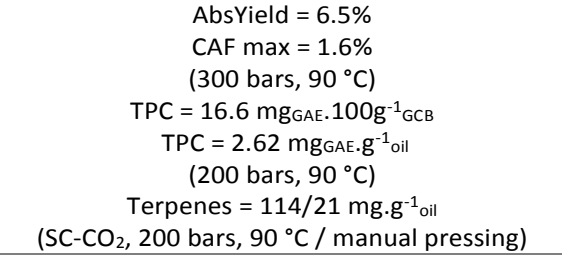 & 208 \\
\hline 24 & $\begin{array}{l}\text { Spent coffee } \\
\text { grounds }\end{array}$ & $\begin{array}{c}60^{\circ} \mathrm{C} \\
400 \text { bars } \\
25 \mathrm{~g} \\
15 \mathrm{~g} \cdot \mathrm{min}^{-1} \mathrm{SC}-\mathrm{CO}_{2} \\
15 / 1.7 \mathrm{~g} \cdot \mathrm{min}^{-1} \mathrm{SC}- \\
\mathrm{CO}_{2} / \mathrm{EtOH}^{-} \\
7.8 \mathrm{~g} \cdot \mathrm{min}^{-1} \mathrm{EtOH} \\
4 \text { separators }(300,200, \\
100 \text { and } 1 \text { bars) } \\
\end{array}$ & TPC, GC-FID (FAC) & $\begin{array}{c}\text { Lipids, } \\
\text { Polyphenols }\end{array}$ & $\begin{array}{c}\text { AbsYield }=25 \% \\
\mathrm{TPC}=\begin{array}{c}4.56 \mathrm{mg} \mathrm{gAE}_{\mathrm{GA}} / \mathrm{g}_{\text {extract }} \\
(\mathrm{EtOH})\end{array} \\
\text { Extract enriched } 4 \text { times in TPC with separators } \\
\mathrm{TPC}=24.1-56.7 \mathrm{mg} \mathrm{mAE}_{\mathrm{GA}} / \mathrm{g}_{\text {extract }} \\
\left(\mathrm{SC}-\mathrm{CO}_{2}\right) \\
\mathrm{TPC}=42-57 \mathrm{mg} \mathrm{GAE}_{\mathrm{GA}} / \mathrm{g}_{\text {extract }} \\
\left(\mathrm{SC}-\mathrm{CO}_{2} / \mathrm{EtOH}\right)\end{array}$ & 196 \\
\hline 25 & $\begin{array}{l}\text { Spent coffee } \\
\text { grounds }\end{array}$ & $\begin{array}{c}40-60^{\circ} \mathrm{C} \\
500 \text { bars (max) } \\
\mathrm{SC}-\mathrm{CO}_{2}+\text { IsoPropanol, } \\
\text { EtOH or Ethyl Lactate }\end{array}$ & $\begin{array}{l}\text { NMR, GC-FID (FAC), } \\
\text { DPPH }\end{array}$ & $\begin{array}{c}\text { Lipids, } \\
\text { antioxidant } \\
\text { activity }\end{array}$ & $\begin{array}{c}\text { C16:0 }+ \text { C18:2 }=76 \% \text { oil FAC } \\
\text { CAF }=0.56-3.96 \mathrm{~g} / 100 \mathrm{~g}_{\text {oil }} \\
\text { DPPH increased } 12.5 \text { times with co-solvent }\end{array}$ & 193 \\
\hline 26 & $\begin{array}{l}\text { Green coffee } \\
\text { bean }\end{array}$ & $\begin{array}{c}20-75^{\circ} \mathrm{C} \\
70-250 \text { bars } \\
\mathrm{SC}-\mathrm{CO}_{2}+\text { US }\end{array}$ & UPLC-MS/MS & CAF & 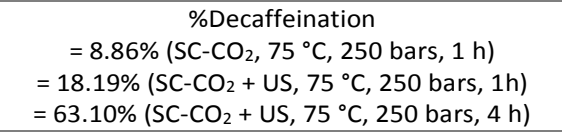 & 209 \\
\hline
\end{tabular}


Fractionation represents an interesting but underdeveloped process for the valorization of coffee and coffee by-products. In theory, it could allow industrials to realize a single extraction with separation of final products such as phenolic, triglycerides and essential oil extracts for example. Hence, the use of multiple separators at different pressures allows the selective recovery of fatty acids, based on their number of carbons or higher added value compounds with different volatility or affinity with the supercritical $\mathrm{CO}_{2} \cdot{ }^{210}$

To conclude, the supercritical $\mathrm{CO}_{2}$ is a true chameleon. By its astonishing capacity to modify its own properties in function of pressure, temperature and co-solvent, the supercritical $\mathrm{CO}_{2}$ allows to selectively enrich or recover high value molecules such as terpenoids or polyphenols in extracts. Moreover, it is a solvent able to mimicry the efficiency of organic solvents for oil recovery in term of quantity (yield) and quality (Fatty Acid Content FAC) of oil recovered, without the major toxic drawbacks.

3.3. Major trends, comparison and sequential combination of SCW and $\mathrm{SC}-\mathrm{CO}_{2}$ applied to coffee and coffee by-products valorization

Table 6 compares subcritical water (SCW) and supercritical $\mathrm{CO}_{2}$ $\left(\mathrm{SC}-\mathrm{CO}_{2}\right)$ extraction used for coffee products and by-products valorization. The two pressurized technics are very different. Indeed, physico-chemical properties of $\mathrm{H}_{2} \mathrm{O}$ and $\mathrm{CO}_{2}$ are initially different. Water remains a polar solvent, even in subcritical conditions. At contrary, carbon dioxide is an apolar solvent. Hence, the obtained final products are also very various, favoring sugars extraction using SCW and lipids extraction using $\mathrm{SC}-\mathrm{CO}_{2}$.

By using them in a sequential manner, these complementary processes could contribute to maximize the recovery of high value molecules from a same raw material obtained from coffee and/or coffee by-products. ${ }^{211}$ Thus, multiple-ways of valorizations of coffee by-products, such as spent coffee grounds, have already been published in reviews and/or investigated on the basis of experimental results obtained using traditional methods, from coffee by-products, ${ }^{10}$, 212 spent coffee grounds ${ }^{213-215}$ or coffee silverskin. ${ }^{44}$ These researches have suggested the concept of biorefinery to generate phenolic compounds, biofuels and/or biocomposites. ${ }^{46,} 216$ The biorefinery concept is in agreement with the long term goal of European Commission of building a sustainable bio-based economy. ${ }^{217}$

Table 6: SCW and SC- $\mathrm{CO}_{2}$ major trends of operating parameters, carried analyses and obtained final products.

\begin{tabular}{ccc}
\hline & Subcritical $\mathrm{H}_{2} \mathrm{O}$ & Supercritical $\mathrm{CO}_{2}$ \\
\hline Parameters & $100-250{ }^{\circ} \mathrm{C}$ & $40-80{ }^{\circ} \mathrm{C}$ \\
& $20-50$ bars & $100-400$ bars \\
& $10-50 \mathrm{~mL} . \mathrm{g}^{-1}$ & \\
\hline
\end{tabular}

\begin{tabular}{ccc}
\hline Static or Dynamic & Dynamic \\
Modifiers: $\mathrm{N}_{2}, \mathrm{CO}_{2}$ & Cosolvent: EtOH \\
Pretreatment: US, & \\
MW, $\mathrm{SC}-\mathrm{CO}_{2}$ & \\
\hline Analyses & TPC (polyphenols) & Yield (oil) \\
TFC (flavonoids) & GC and HPLC (fatty \\
TSC, RSs (sugars) & acids composition, \\
& DPPH, ABTS, FRAP, & (terpenoids, \\
ORAC (antioxidant & sterols, \\
capacity) & tocopherols, \\
HPLC (chlorogenic & caffeine) \\
acids, caffeine, & TPC (polyphenols) \\
oligosaccharides, & DPPH (antioxidant \\
& monosaccharides) & capacity) \\
\hline Final products & Bioactive molecules & Bioactive oil \\
(ingredient) & (ingredient) \\
& Bio-crude oil (energy) & Biodiesel (energy) \\
\hline
\end{tabular}

Hence, experiments have been performed on combination of double or triple ways of valorization. For example, spent coffee grounds have been tested for production of polyhydroxyalkanoates (PHA) and carotenoids. ${ }^{89}$ It has also been used to generate phenolic compounds and bioenergy. ${ }^{218}$ Finally, SCG has been proposed for production of biodiesel, biocrude oil and biochar. ${ }^{88}$

In agreement with the results of the literature of the last twenty years, Green Solvent Bio-Refinery concept (GreSBiR) using subcritical $\mathrm{H}_{2} \mathrm{O}$ and supercritical $\mathrm{CO}_{2}$ for the full valorization of coffee and coffee by-products can be proposed (Figure 12). SC- $\mathrm{CO}_{2}$ under different pressures with or without co-solvent allows producing sequentially, multiple oils with different properties. Otherwise, an extraction at high pressure with co-solvent can be followed by fractionation at different pressure and solvent composition. SCW at different time and temperatures of exposition allows producing sequentially, bioactive extracts, bioactive sugars, bioethanol, biocrude oil and/or biochar.

This biorefinery could be able transforming coffee and coffee by-products into various products with higher value owing their applications in energy, cosmetic, nutraceutical or pharmaceutical fields. Nevertheless, life cycle assessment (LCA) and economic analysis are required to estimate the industrial interest of such biorefinery. ${ }^{219}$

\section{Conclusions and perspectives}

The current review reports the great interest of subcritical water and supercritical carbon dioxide used for coffee and coffee by-products and reports the following advantages: i) similar or better amount and quality of extracts produced by $\mathrm{SCW}$ and $\mathrm{SC}-\mathrm{CO}_{2}$ in comparison with traditional methods; ii) customized properties of $\mathrm{SC}-\mathrm{CO}_{2}$ to selectively extract high value molecules; iii) triple action of SCW as solvent, reagent and catalyst; iv) wide range of final products covered by the two 
technologies ( $\mathrm{SCW}$ and $\mathrm{SC}-\mathrm{CO}_{2}$ ) and $\mathrm{v}$ ) the reduction of environmental impact by limiting toxic solvents and/or required catalyst with the use of SCW and $\mathrm{SC}-\mathrm{CO}_{2}$.

For subcritical $\mathrm{H}_{2} \mathrm{O}$, the prime influent parameter is the combination of temperature/time. Carbohydrates and polyphenols recovery has been performed with SCW at moderate temperature $\left(150-220{ }^{\circ} \mathrm{C}\right)$ with shorter time of extraction (10-30 min). Biocrude oil and biochar production have been performed with SCW at high temperature (220-300 ${ }^{\circ} \mathrm{C}$ ). The reported results for carbohydrates and polyphenols under those conditions have been demonstrated to be more efficient than any other traditional or non-conventional technologies.

Perspectives could be a step back to reinforce the fundamental knowledge about the black box phenomena that occurred during SCW applied to biomass. More specifically, deeper studies are required on i) the solubilization under the chosen conditions; ii) the kinetic of the hydrolysis of polysaccharides and oligosaccharides; iii) the kinetic of degradation of monosaccharides.

For the SCW solubilization of oligosaccharides of different molecular weights, no experiment has been carried out to measure the unique solubilization part without SCW hydrolysis and corresponding solubilization of lower weight degradation products. The addition of a hydrolysis inhibitor could allow assessing the influence of the solubilization properties of oligosaccharides in SCW at different temperatures.

For kinetic of hydrolysis, it could be interesting to quantify the different poly- or oligo-saccharides as a function of time to determine if a monosaccharide pattern (galactose $v s$ mannose) is more selectively hydrolyzed. The influence of the nature of glycosidic binding on the hydrolysis rate should be also evaluated.

The measurement of kinetic of degradation is essential too. Hence, a comparison between kinetic of hydrolysis and kinetic of degradation could help the researchers anticipating their results instead of taking an empirical approach. For example, if the kinetic of degradation is ten times faster than the one of hydrolysis, there is no chance to recover some high value molecules, despite their production after hydrolysis.

The lack of control during SCW applied to coffee and coffee by-products makes the production of monosaccharides difficult. It results in several limitations such as low yield in SCW at low temperature and high degradation in SCW at high temperatures. With a selective and reversible protective agent of monosaccharides, higher temperature or longer time of extraction could be further used to get extremely high yield. No research has been carried out yet, hence, the acetylation of monosaccharides could be the solution. ${ }^{220}$

For supercritical $\mathrm{CO}_{2}$, the studied literature dealing with coffee and coffee by-products has highlighted a chameleon technology with unlimited tunability to selectively extract solutes for biomass valorization. The prime influent parameters are reporting the pressure and the co-solvent addition. Supercritical carbon dioxide has been used at relatively high pressure (300-400 bars) for lipids extraction and with EtOH addition as modifier for phenolic compounds recovery. The reported results with $\mathrm{SC}-\mathrm{CO}_{2}$ have been demonstrated the same efficiency in term of amount and quality of oil but present a better selectivity of high value molecules such as terpenoids sterols, tocopherols, caffeine, polyphenols in comparison with the use of hexane Soxhlet method.

Volatile lipophilic compounds such as terpenoids, sterols and tocopherols can be extracted more selectively at low pressure (100-200 bars). Triglycerides and volatile compounds are both extracted at high pressure (300-400 bars). Volatile, triglycerides and phenolic compounds are all extracted under high pressure (300-400 bars) with addition of EtOH.

The influence of the residual water in the dry coffee byproducts used under supercritical $\mathrm{CO}_{2}$ is rarely reported in the literature. Hence, Dunford et al. have observed that majority of water moisture remains in the material, but, a small part is extracted from the media. ${ }^{221}$ In addition, after deduction of the extracted mass of water, significant differences of yield (5.5-7.1 g) have been reported at different moisture levels (12.7-37.8 \% $\mathrm{w} / \mathrm{w})$ at $75{ }^{\circ} \mathrm{C}, 600$ bars for examples. Since the pressure and temperature of critical point depend of the proportion of $\mathrm{CO}_{2} / \mathrm{H}_{2} \mathrm{O}$ the mixture, it is possible than residual water play a significant part to influence the extraction and nature of extracts. $^{222}$ More specifically, the residual subcritical or supercritical $\mathrm{H}_{2} \mathrm{O}$ in presence of $\mathrm{CO}_{2}$ becomes a strong acid able to hydrolyze lignocellulosic materials such as cellulose, hemicellulose, lignin as suggested by Morais et al. ${ }^{132}$

Perspectives of $\mathrm{SC}-\mathrm{CO}_{2}$ applied to coffee and coffee byproducts could focus on i) the improvement of extraction and ii) the development of novel technologies of fractionation.

Yield of extraction, selectivity and $\mathrm{CO}_{2}$ consumption can be improved with pretreatment such as ultrasound (US) or microwave (MW) or ionic liquid (IL) or deep eutectic solvent (DES). ${ }^{209,} 223$

Polarity modification during $\mathrm{SC}-\mathrm{CO}_{2}$ extraction has already been performed by the addition of water or alcohols such as ethanol or isopropyalcohol. Hence, the addition of novel hydrophilic solvent such as DES during $\mathrm{SC}-\mathrm{CO}_{2}$ has never been performed. Moreover, DES is not soluble in $\mathrm{SC}-\mathrm{CO}_{2}$ but SC- $\mathrm{CO}_{2}$ is slightly soluble in DES. Hence, the addition of DES could be used in static mode without be totally consumed with dynamic extraction by $\mathrm{SC}-\mathrm{CO}_{2}$, resulting DES-free extract enriched in polar compounds.

Hemi-synthesis is an understudied field in $\mathrm{SC}-\mathrm{CO}_{2}$ for coffee and coffee by-products valorization. The co-solvent could become reagent introduced simultaneously with $\mathrm{SC}-\mathrm{CO}_{2}$ to extract and functionalize triglycerides. For example, unsaturated fatty acids could be oxidized to form higher value products than the biodiesel obtained through transesterification reactions. Such possibility has been studied for the oxidation of oleic acid into pelargonic and azelaic acids, with ozone or potassium permanganate under supercritical $\mathrm{CO}_{2} \cdot{ }^{224}$

The fractionation through the use of $\mathrm{SC}-\mathrm{CO}_{2}$ technology should be more investigated. The pressurization with a more apolar solvent than $\mathrm{CO}_{2}$ could allow selectively precipitating polar compounds in separators. Otherwise, the addition of a resin or adsorbent inside the separator could trap phenolic 
compounds, despite an extra step to desorb the high value compounds.

To conclude, subcritical $\mathrm{H}_{2} \mathrm{O}$ and supercritical $\mathrm{CO}_{2}$ are greener, more efficient and more selective than traditional methods for the valorization of coffee and coffee by-products. Moreover, the two technologies are complementary. Used sequentially, the subcritical $\mathrm{H}_{2} \mathrm{O}$ and supercritical $\mathrm{CO}_{2}$ unable covering almost all the possibilities of valorization of coffee and coffee by-products. Hence, the knowledge and way to use those technologies have to be further investigated to ensure the rightful place of subcritical $\mathrm{H}_{2} \mathrm{O}$ and supercritical $\mathrm{CO}_{2}$ in the field of biomass valorization, including coffee and coffee byproducts.

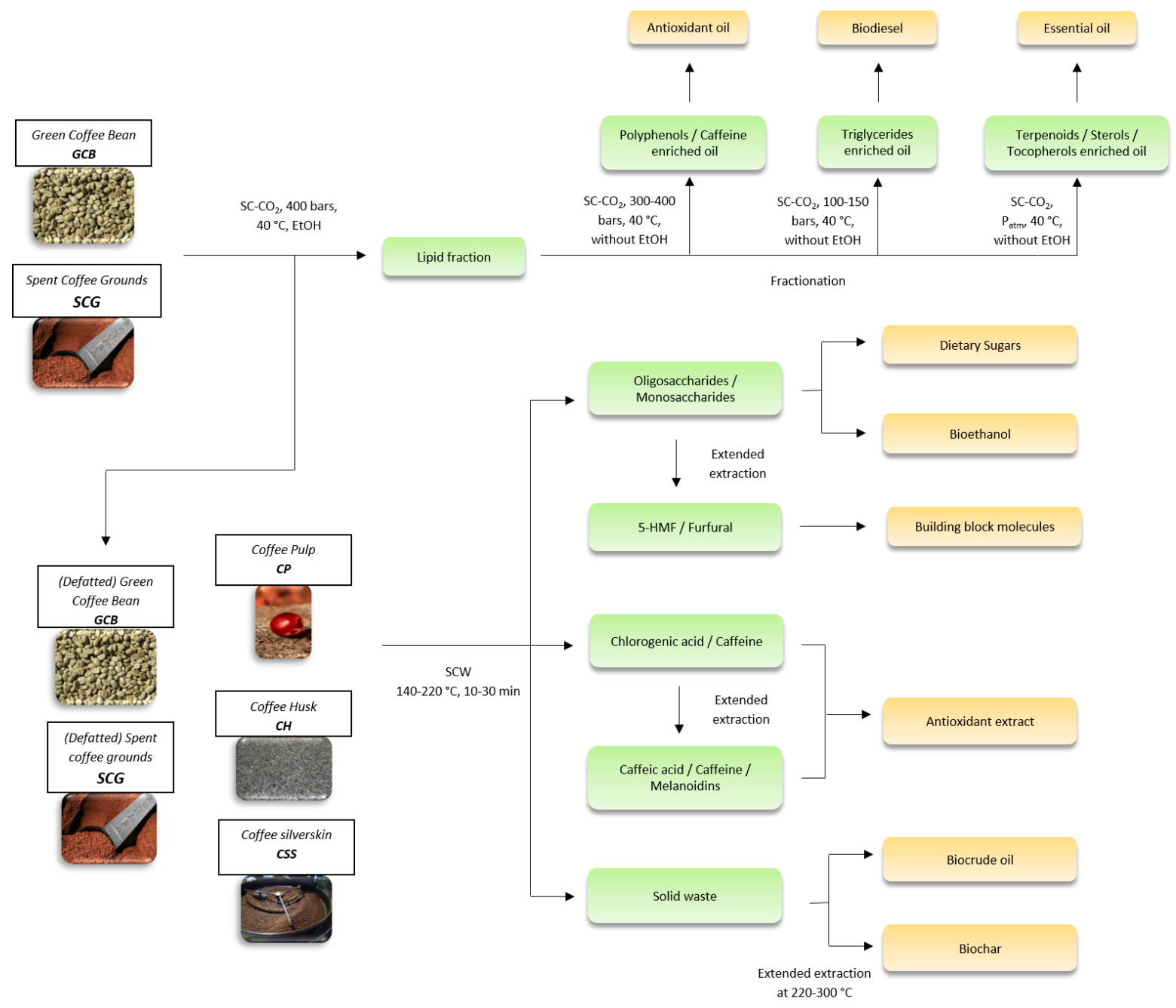

Figure 2: Green Solvent Bio-Refinery (GreSBiR) with subcritical water (SCW) and supercritical carbon dioxide $\left(\mathrm{SC}^{-} \mathrm{CO}_{2}\right)$ applied to coffee and coffee by-products. 


\section{Conflicts of interest}

There are no conflicts to declare.

\section{Acknowledgements}

The authors gratefully acknowledge the Auvergne-Rhône-Alpes French Region for the awarding of the PhD scholarship to Alexandre Vandeponseele and for $\mathrm{sc}-\mathrm{CO}_{2}$ unit funding through the Pack Ambition Recherche program. They also acknowledge the TRIALP company and the Université Savoie Mont Blanc Foundation for their financial supports.

\section{References}

1. X. M. Guo, E. Trably, E. Latrille, H. Carrere and J.-P. Steyer International journal of hydrogen energy, 2010, 35, 1066010673.

2. M. Koller, R. Bona, G. Braunegg, C. Hermann, P. Horvat, M. Kroutil, J. Martinz, J. Neto, L. Pereira and P. Varila, Biomacromolecules, 2005, 6, 561-565.

3. P. Ramos, S. A. Santos, Â. R. Guerra, O. Guerreiro, L. Felício, E. Jerónimo, A. J. Silvestre, C. P. Neto and M. Duarte, Industrial Crops and Products, 2013, 46, 359-368.

4. M. Zwingelstein, M. Draye, J.-L. Besombes, C. Piot and G. Chatel, ACS Sustainable Chemistry \& Engineering, 2019, 7, 8310-8316.

5. N.-Y. Kim, M.-K. Jang, D.-G. Lee, K. H. Yu, H. Jang, M. Kim, S. G. Kim, B. H. Yoo and S.-H. Lee, Nutrition research and practice, 2010, 4, 16-22.

6. T. J. Mason, F. Chemat and M. Vinatoru, Current Organic Chemistry, 2011, 15, 237-247.

7. Y. Chisti, Biotechnology Advances, 2007, 25, 294-306.

8. Y. Chen, L.-p. Sun, Z.-h. Liu, G. Martin and Z. Sun, in Chemistry and Chemical Technologies in Waste Valorization, Springer, 2017, pp. 151-188.

9. R. A. Carciochi, L. G. D'Alessandro, P. Vauchel, M. M. Rodriguez, S. M. Nolasco and K. Dimitrov, in Ingredients Extraction by Physicochemical Methods in Food, Elsevier, 2017, pp. 191-228.

10. P. S. Murthy and M. Madhava Naidu, Resources, Conservation and Recycling, 2012, 66, 45-58.

11. P. T. Anastas and J. C. Warner, Green chemistry: theory and practice, Oxford University Press, Oxford [England]; New York, 1998.

12. A. Shitu, S. Izhar and T. Tahir, 2015.

13. D. R. Joshi and N. Adhikari, Journal of Pharmaceutical Research International, 2019, 1-18.

14. P. Cintas and J.-L. Luche, Green Chemistry, 1999, 1, 115125.

15. F. Chemat, N. Rombaut, A.-G. Sicaire, A. Meullemiestre, A.S. Fabiano-Tixier and M. Abert-Vian, Ultrasonics Sonochemistry, 2017, 34, 540-560.
16. G. Chatel, Sonochemistry: New Opportunities For Green Chemistry, World Scientific Publishing Company, 2016.

17. R. S. Varma, Green Chemistry, 1999, 1, 43-55.

18. G. Chatel and R. S. Varma, Green Chemistry, 2019, 21 , 6043-6050.

19. E. Vorobiev and N. Lebovka, Enhancing extraction processes in the food industry, 2011, 25-84.

20. Z. Li, Y. Fan and J. Xi, Food chemistry, 2019, 277, 246-260.

21. K. N. Marsh, J. A. Boxall and R. Lichtenthaler, Fluid Phase Equilibria, 2004, 219, 93-98.

22. Y. Marcus, in Deep Eutectic Solvents, ed. Y. Marcus, Springer International Publishing, Cham, 2019, DOI: 10.1007/978-3-030-00608-2_6, pp. 185-191.

23. K. D. O. Vigier, G. Chatel and F. Jerome, ChemCatChem, 2015, 7, 1250-1260.

$24 . \quad J$. Zhang, C. Wen, H. Zhang, Y. Duan and H. Ma, Trends in Food Science \& Technology, 2020, 95, 183-195.

25. K.-Y. Khaw, M.-O. Parat, P. N. Shaw and J. R. Falconer, Molecules, 2017, 22, 1186.

26. A. Stolle, T. Szuppa, S. E. S. Leonhardt and B. Ondruschka, Chemical Society Reviews, 2011, 40, 2317-2329.

27. F. Chemat, A. S. Fabiano-Tixier, M. A. Vian, T. Allaf and E. Vorobiev, TrAC Trends in Analytical Chemistry, 2015, 71, 157-168.

28. M. Ruesgas-Ramón, M. C. Figueroa-Espinoza and E. Durand, Journal of agricultural and food chemistry, 2017, 65, 3591-3601.

29. X. Peng, M.-H. Duan, X.-H. Yao, Y.-H. Zhang, C.-J. Zhao, Y.G. Zu and Y.-J. Fu, Separation and Purification Technology, 2016, 157, 249-257.

30. T. Wang, F. He and G. Chen, Journal of Functional Foods, 2014, 7, 101-111.

C. C. Teo, S. N. Tan, J. W. H. Yong, C. S. Hew and E. S. Ong, Journal of Chromatography A, 2010, 1217, 2484-2494.

32. E. Kiran, J. F. Brennecke, E. American Institute of Chemical and M. Annual, 1993.

33. M. Tsar, M. Ghasemiziarhani and K. Ofori, presented in part at the EAGE Annual Conference \& Exhibition incorporating SPE Europec, London, UK, 2013/6/10/, 2013.

34. J. Peach and J. Eastoe, Beilstein journal of organic chemistry, 2014, 10, 1878-1895.

35. P. Rabinarayan and S. Padilama, Journal of Advanced Pharmaceutical Science And Technology, 2013, 1, 13-36.

36. http://www.ico.org/ Accessed the 31/01/2020).

37. S. Ponte, World Development, 2002, 30, 1099-1122.

38. http://www.fao.org/home/en/ Accessed the 30/01/2020).

39. L. Fan, A. T. Soccol, A. Pandey and C. R. Soccol, Micología Aplicada International, 2003, 15, 15-21.

40. F. Leifa, A. Pandey and C. R. Soccol, Brazilian Archives of Biology and Technology, 2001, 44, 205-212.

A. Pandey, C. R. Soccol, P. Nigam, D. Brand, R. Mohan and S. Roussos, Biochemical Engineering Journal, 2000, 6, 153162.

42. Teixeira, Food and Bioprocess Technology, 2011, 4,661 . 
43

M. D. del Castillo, J. M. Ames and M. H. Gordon, Journal of agricultural and food chemistry, 2002, 50, 3698-3703.

44.

Y. Narita and K. Inouye, Food Research International, 2014, 75. 61, 16-22.

45. A. S. Franca, J. C. F. Mendonça and S. D. Oliveira, LWT Food Science and Technology, 2005, 38, 709-715.

46. T. M. Mata, A. A. Martins and N. S. Caetano, Bioresource technology, 2018, 247, 1077-1084.

47. M. Echeverria and M. Nuti, The Open Waste Management Journal, 2017, 10.

48. I. Hečimović, A. Belščak-Cvitanović, D. Horžić and D. Komes, Food chemistry, 2011, 129, 991-1000.

49. A. Farah, T. de Paulis, L. C. Trugo and P. R. Martin, Journal of agricultural and food chemistry, 2005, 53, 1505-1513.

50. R. Padmapriya, J. A. Tharian and T. Thirunalasundari, Int. J. Curr. Sci, 2013, 9, 83-91.

51. T. Masuko, A. Minami, N. Iwasaki, T. Majima, S.-I. Nishimura and Y. C. Lee, Analytical biochemistry, 2005, 339, 69-72.

52. M. Dubois, K. Gilles, J. Hamilton, P. Rebers and F. Smith, Nature, 1951, 168, 167-167.

53. M. Dubois, K. A. Gilles, J. K. Hamilton, P. t. Rebers and F. Smith, Analytical chemistry, 1956, 28, 350-356.

54. R. Dreywood, Industrial \& Engineering Chemistry Analytical Edition, 1946, 18, 499-499.

55.

56.

57

58

59

D. L. Morris, Science (Washington), 1948, 107, 254-255.

F. A. Loewus, Analytical Chemistry, 1952, 24, 219-219.

G. L. Miller, Analytical chemistry, 1959, 31, 426-428.

R. Hu, L. Lin, T. Liu, P. Ouyang, B. He and S. Liu, Journal of Biobased Materials and Bioenergy, 2008, 2, 156-161. food chemistry, 1990, 38, 389-392.

60. A. Sluiter, B. Hames, R. Ruiz, C. Scarlata, J. Sluiter and D. Templeton, Golden: National Renewable Energy Laboratory, 2006.

61. P. Shanmugavelan, S. Y. Kim, J. B. Kim, H. W. Kim, S. M. Cho, S. N. Kim, S. Y. Kim, Y. S. Cho and H. R. Kim, Carbohydrate Research, 2013, 380, 112-117.

62. W. Buchberger, K. Winsauer and C. Breitwieser, Fresenius' Zeitschrift für analytische Chemie, 1983, 315, 518-520.

63. S. Honda, E. Akao, S. Suzuki, M. Okuda, K. Kakehi and J. Nakamura, Analytical biochemistry, 1989, 180, 351-357.

64. W. Wang, F. Chen, Y. Wang, L. Wang, H. Fu, F. Zheng and L. Beecher, Food chemistry, 2018, 254, 158-164.

$65 . \quad$ C. M. Montero, M. R. Dodero, D. G. Sánchez and C. Barroso, Chromatographia, 2004, 59, 15-30.

66.

67.

68 H. L. A Didanna, Conference Proceedings, 2014.

L. S. Oliveira and A. S. Franca, in Coffee in health and disease prevention, Elsevier, 2015, pp. 283-291.

D. I. Givens and W. P. Barber, Agricultural Wastes, 1986, 18, 69-72.

69. R. Cruz, P. Baptista, S. Cunha, J. A. Pereira and S. Casal, Molecules, 2012, 17, 1535-1547.

70. H. Kassa, H. Suliman and T. Workayew, Ethiopian Journal of Environmental Studies and Management, 2011, 4.

71. L. Fan, A. Pandey, R. Mohan and C. Soccol, Acta Biotechnologica, 2000, 20, 41-52.

72. M. Velissariou, R. J. Laudano, P. M. Edwards, S. M. Stimpson and R. L. Jeffries, Journal, 2010.

73. J. A. M. Fuentes, R. A. Alemán, L. A. Chavarría, I. M. V. Murillo, N. P. Alvarado and I. M. Fernández, Journal of Agricultural Science, 2020, 12.
74.

A. Heeger, A. Kosińska-Cagnazzo, E. Cantergiani and W. Andlauer, Food chemistry, 2017, 221, 969-975.

T.-A. Kua, A. Arulrajah, S. Horpibulsuk, Y.-J. Du and S.-L. Shen, Construction and Building Materials, 2016, 115, 565575.

A. Lachheb, A. Allouhi, M. El Marhoune, R. Saadani, T. Kousksou, A. Jamil, M. Rahmoune and O. Oussouaddi, Journal of Cleaner Production, 2019, 209, 1411-1419.

D. Eliche-Quesada, L. Pérez-Villarejo, F. Iglesias-Godino, C. Martínez-García and F. Corpas-Iglesias, Advances in Applied Ceramics, 2011, 110, 225-232.

A. Arulrajah, F. Maghoolpilehrood, M. M. Disfani and S. Horpibulsuk, Journal of cleaner production, 2014, 72, 181186.

N. E. Dávila-Guzmán, F. de Jesús Cerino-Córdova, E. SotoRegalado, J. R. Rangel-Mendez, P. E. Díaz-Flores, M. T. Garza-Gonzalez and J. A. Loredo-Medrano, CLEAN-Soil, Air, Water, 2013, 41, 557-564.

A. A. Chavan, J. Pinto, I. Liakos, I. S. Bayer, S. Lauciello, A. Athanassiou and D. Fragouli, ACS Sustainable Chemistry \& Engineering, 2016, 4, 5495-5502.

E. F. Lessa, M. L. Nunes and A. R. Fajardo, Carbohydrate polymers, 2018, 189, 257-266.

X. Ma and F. Ouyang, Applied Surface Science, 2013, 268, 566-570.

Y. S. Choi, S. K. Choi, S. J. Kim, Y. W. Jeong, R. Soysa and T. Rahman, Environmental Progress \& Sustainable Energy, 2017, 36, 655-661.

W.-T. Tsai, S.-C. Liu and C.-H. Hsieh, Journal of Analytical and Applied Pyrolysis, 2012, 93, 63-67.

J. Calzada, O. León, M. Arriola, F. Micheo, C. Rolz, R. León and J. Menchu, Biotechnology letters, 1981, 3, 713-716.

D. Dadi, A. Beyene, K. Simoens, J. Soares, M. Demeke, J. Thevelein, K. Bernaerts, P. Luis and B. Van der Bruggen, International journal of environmental science and technology, 2018, 15, 821-832.

B. Gouvea, C. Torres, A. Franca, L. Oliveira and E. Oliveira, Biotechnology letters, 2009, 31, 1315-1319.

D. R. Vardon, B. R. Moser, W. Zheng, K. Witkin, R. L. Evangelista, T. J. Strathmann, K. Rajagopalan and B. K. Sharma, ACS Sustainable Chemistry \& Engineering, 2013, 1, 1286-1294.

S. Obruca, P. Benesova, D. Kucera, S. Petrik and I. Marova, New biotechnology, 2015, 32, 569-574.

S. Obruca, S. Petrik, P. Benesova, Z. Svoboda, L. Eremka and I. Marova, Applied microbiology and biotechnology, 2014, 98, 5883-5890.

91. M. A. Heckman, J. Weil and E. G. De Mejia, Journal of food science, 2010, 75, R77-R87.

L. Bresciani, L. Calani, R. Bruni, F. Brighenti and D. Del Rio, Food Research International, 2014, 61, 196-201.

M. Clifford and J. Ramirez-Martinez, Food Chemistry, 1991, 40, 35-42.

J. Simões, P. Madureira, F. M. Nunes, M. do Rosário Domingues, M. Vilanova and M. A. Coimbra, Molecular nutrition \& food research, 2009, 53, 1036-1043.

95. A. R. Prihadi, A. Maimulyanti and B. Mellisani, Rasayan Journal of Chemistry, 2020, 13, 955-959.

96. D. Scully, A. Jaiswal and N. Abu-Ghannam, Bioengineering, 2016, 3, 33. 
97

M. Martin-Smith and W. Sneader, Progress in Drug Research/Fortschritte der Arzneimittelforschung/Progrès des recherches pharmaceutiques, 2013, 13, 11.

98. J. Marto, L. Gouveia, B. Chiari, A. Paiva, V. Isaac, P. Pinto, P Simões, A. Almeida and H. Ribeiro, Industrial Crops and Products, 2016, 80, 93-100.

99. O. Folin and V. Ciocalteu, Journal of biological chemistry, 1927, 73, 627-650.

100. A. Panusa, A. Zuorro, R. Lavecchia, G. Marrosu and R. Petrucci, Journal of agricultural and food chemistry, 2013, 61, 4162-4168.

101. P. S. Murthy and M. M. Naidu, Food and Bioprocess Technology, 2012, 5, 897-903.

102. O. Dellalibera, B. Lemaire and S. Lafay, Phytotherapie, 2006, 4, 194-197.

103. M. E. dos Santos Diamantino, A. C. T. A. Chaves, D. de Melo Silva, G. da Silveira Lemos and R. F. Queiroz, International Journal of Advanced Engineering Research and Science, 2019, 6.

104. V. L. Singleton, R. Orthofer and R. M. Lamuela-Raventós, in Methods in enzymology, Elsevier, 1999, vol. 299, pp. 152178.

105. A. Pękal and K. Pyrzynska, Food Analytical Methods, 2014, 7, 1776-1782.

106. B. Christ and K. Müller, Archiv der Pharmazie, 1960, 293, 1033-1042.

107. K. Thaipong, U. Boonprakob, K. Crosby, L. Cisneros-Zevallos and D. H. Byrne, Journal of food composition and analysis, 2006, 19, 669-675.

108. O. P. Sharma and T. K. Bhat, Food chemistry, 2009, 113, 1202-1205.

109. T. Conde and S. I. Mussatto, Preparative Biochemistry and Biotechnology, 2016, 46, 406-409.

110. H. M. Ribeiro, M. Allegro, J. Marto, B. Pedras, N. G. Oliveira, A. Paiva, S. Barreiros, L. d. M. Gonçalves and P. Simões, ACS Sustainable Chemistry \& Engineering, 2018, 6, 6289-6295.

111. L. F. Ballesteros, J. A. Teixeira and S. I. Mussatto, Carbohydrate polymers, 2017, 157, 258-266.

112. H. Xu, W. Wang, X. Liu, F. Yuan and Y. Gao, Industrial Crops and Products, 2015, 76, 946-954

113. Y.-F. Shang, J.-L. Xu, W.-J. Lee and B.-H. Um, South African Journal of Botany, 2017, 109, 75-80.

114. M. N. Clifford, K. L. Johnston, S. Knight and N. Kuhnert, Journal of agricultural and food chemistry, 2003, 51, 29002911.

115. M. Clifford, in Coffee, Springer, 1985, pp. 153-202.

116. N. P. Rodrigues and N. Bragagnolo, Journal of Food Composition and Analysis, 2013, 32, 105-115.

117. K. Belguidoum, H. Amira-Guebailia, Y. Boulmokh and O. Houache, Journal of the Taiwan Institute of Chemical Engineers, 2014, 45, 1314-1320.

118. M. C. Roman, J. Hildreth and S. Bannister, Journal of AOAC International, 2013, 96, 933-941.

119. A. Z. Tulio Jr, R. N. Reese, F. J. Wyzgoski, P. L. Rinaldi, R. Fu, J. C. Scheerens and A. R. Miller, Journal of agricultural and food chemistry, 2008, 56, 1880-1888.

120. C. Sheng and J. Azevedo, Biomass and bioenergy, 2005, 28, 499-507.

121. M. M. Cascant, C. Breil, S. Garrigues, M. de la Guardia, A. S. Fabiano-Tixier and F. Chemat, Analytical and Bioanalytical Chemistry, 2017, 409, 3527-3539.
122. K. Speer and I. Kölling-Speer, Brazilian Journal of Plant Physiology, 2006, 18, 201-216.

123. P. S. Sukhija and D. Palmquist, Journal of agricultural and food chemistry, 1988, 36, 1202-1206

124. W. W. Christie, Advances in lipid methodology, 1993, 2 e111.

125. Z. Jiang, C. Kempinski and J. Chappell, Current protocols in plant biology, 2016, 1, 345-358.

126. M. Huang, J.-J. Lu, M.-Q. Huang, J.-L. Bao, X.-P. Chen and Y.-T. Wang, Expert opinion on investigational drugs, 2012, 21, 1801-1818.

127. A. Silva-Santos, A. Antunes, H. Bizzo, C. D'avila and L. Souza-Santos, Rev Bras Farmacogn, 2004, 14, 48-50.

S. Abumweis, R. Barake and P. Jones, Food \& Nutrition Research, 2008, 52, 1811.

129. M. L. Thakur and U. S. Srivastava, Nutrition research, 1996, 16, 1767-1809.

130. A. T. Getachew, Y. J. Cho and B. S. Chun, International journal of biological macromolecules, 2018, 109, 711-719.

131. A. T. Getachew and B. S. Chun, Journal of cleaner production, 2017, 142, 3719-3727.

132. A. R. Morais, A. M. da Costa Lopes and R. Bogel-Łukasik, Chemical reviews, 2015, 115, 3-27.

133. B. M. Pedras, M. Nascimento, I. Sá-Nogueira, P. Simões, A Paiva and S. Barreiros, Journal of Industrial and Engineering Chemistry, 2019, 72, 453-456.

134. X. Lü and S. Saka, The Journal of Supercritical Fluids, 2012, 61, 146-156.

135. S. H. Khajavi, Y. Kimura, T. Oomori, R. Matsuno and S. Adachi, Journal of Food Engineering, 2005, 68, 309-313.

136. T. M. Aida, Y. Sato, M. Watanabe, K. Tajima, T. Nonaka, H. Hattori and K. Arai, The Journal of supercritical fluids, 2007, 40, 381-388.

137. M. Mohan, R. Timung, N. N. Deshavath, T. Banerjee, V. V. Goud and V. V. Dasu, RSC advances, 2015, 5, 103265103275.

138. D. Lachos-Perez, G. Tompsett, P. Guerra, M. Timko, M. Rostagno, J. Martínez and T. Forster-Carneiro, Bioresource technology, 2017, 243, 1069-1077.

139. D. Zhang, F. Montanés, K. Srinivas, T. Fornari, E. Ibánez and J. W. King, Industrial \& engineering chemistry research, 2010, 49, 6691-6698.

140. M. Plaza and C. Turner, TrAC Trends in Analytical Chemistry, 2015, 71, 39-54.

141. M. Sasaki, B. Kabyemela, R. Malaluan, S. Hirose, N. Takeda, T. Adschiri and K. Arai, The Journal of Supercritical Fluids, 1998, 13, 261-268.

142. S. Haghighat Khajavi, S. Ota, Y. Kimura and S. Adachi, Journal of agricultural and food chemistry, 2006, 54, 36633667.

143. D.-M. Gao, T. Kobayashi and S. Adachi, Bioscience, biotechnology, and biochemistry, 2015, 79, 1005-1010.

144. L. F. Ballesteros, M. A. Cerqueira, J. A. Teixeira and S. I. Mussatto, Carbohydrate polymers, 2015, 127, 347-354.

145. B. M. Dorsey and M. A. Jones, in Handbook of coffee processing by-products, Elsevier, 2017, pp. 27-62. C. Monente, I. A. Ludwig, A. Irigoyen, M. a.-P. De Peña and C. n. Cid, Journal of agricultural and food chemistry, 2015, 63, 4327-4334.

147. T. Sato, T. Takahata, T. Honma, M. Watanabe, M. Wagatsuma, S. Matsuda, R. L. Smith Jr and N. Itoh, 
Industrial \& Engineering Chemistry Research, 2018, 57, 175. 7624-7632.

148. P. Khuwijitjaru, J. Plernjit, B. Suaylam, S. Samuhaseneetoo, R. Pongsawatmanit and S. Adachi, The Canadian Journal of Chemical Engineering, 2014, 92, 810-815.

149. P. Khuwijitjaru, B. Suaylam and S. Adachi, Journal of agricultural and food chemistry, 2014, 62, 1945-1949.

$150 . \quad$ L. F. Ballesteros, M. J. Ramirez, C. E. Orrego, J. A. Teixeira and S. I. Mussatto, Journal of Food Engineering, 2017, 199, 1-8.

151. Y. Narita and K. Inouye, Food chemistry, 2012, 135, 943949.

152. C. Delgado-Andrade, J. A. Rufián-Henares and F. J. Morales, Journal of agricultural and food chemistry, 2005, 53, 78327836.

153. D. Perrone, A. Farah and C. M. Donangelo, Journal of agricultural and food chemistry, 2012, 60, 4265-4275.

154. A. S. Moreira, F. M. Nunes, C. Simões, E. Maciel, P. Domingues, M. R. M. Domingues and M. A. Coimbra, Food chemistry, 2017, 227, 422-431.

155. M. Plaza, M. Amigo-Benavent, M. D. Del Castillo, E. Ibáñez and M. Herrero, Food Research International, 2010, 43, 2341-2348.

156. S. Azam, N. Hadi, N. U. Khan and S. M. Hadi, Medical Science Monitor, 2003, 9, BR325-BR330.

157. J.-X. Dong, Q. Li, Z.-C. Tan, Z.-H. Zhang and Y. Liu, The Journal of Chemical Thermodynamics, 2007, 39, 108-114.

158. A. T. Getachew and B. S. Chun, Innovative food science \& emerging technologies, 2016, 38, 24-31.

159. N. Punbusayakul, N. Saim, Z. A. Haiyee, W. Sarnkhuankaew and R. Osman, Science Letters, 2014, 8, 34-40.

160. N. A. Al-Dhabi, K. Ponmurugan and P. M. Jeganathan, Ultrasonics sonochemistry, 2017, 34, 206-213.

161. P. Arauzo, M. Lucian, L. Du, M. Olszewski, L. Fiori and A. Kruse, Biomass and Bioenergy, 2020, 139, 105616.

162. M. Pettinato, A. A. Casazza and P. Perego, Food and bioproducts processing, 2019, 114, 227-234

163. D. E. Yoo, K. M. Jeong, S. Y. Han, E. M. Kim, Y. Jin and J. Lee, Food chemistry, 2018, 255, 357-364.

164. A. Demirbas and G. Arin, Energy sources, 2002, 24, 471482.

165. S. Xiu and A. Shahbazi, Renewable and Sustainable Energy Reviews, 2012, 16, 4406-4414.

166. Z. Liu, A. Quek, S. K. Hoekman and R. Balasubramanian, Fuel, 2013, 103, 943-949.

167. L. Yang, L. Nazari, Z. Yuan, K. Corscadden and C. C. Xu, Biomass and Bioenergy, 2016, 86, 191-198.

168. D. Kim, K. Lee, D. Bae and K. Y. Park, Journal of Material Cycles and Waste Management, 2017, 19, 1036-1043.

169. J. P. Bok, H. S. Choi, Y. S. Choi, H. C. Park and S. J. Kim, Energy, 2012, 47, 17-24.

170. Zosel, US Pat., 4,260,639, 1981).

171. Zosel, US Pat., 3,806,619, 1974).

172. S. N. Katz, in Coffee: Volume 2: Technology, eds. R. J. Clarke and R. Macrae, Springer Netherlands, Dordrecht, 1987, DOI: 10.1007/978-94-009-3417-7_3, pp. 59-71.

173. I. De Marco, S. Riemma and R. lannone, The Journal of Supercritical Fluids, 2018, 133, 393-400.

174. R. M. Couto, J. Fernandes, M. G. Da Silva and P. C. Simões, The Journal of Supercritical Fluids, 2009, 51, 159-166.
M. Mariotti-Celis, M. Martínez-Cifuentes, N. HuamánCastilla, M. Vargas-González, F. Pedreschi and J. PérezCorrea, Molecules, 2018, 23, 21.

176. P. Mayanga-Torres, D. Lachos-Perez, C. Rezende, J. Prado, Z. Ma, G. Tompsett, M. Timko and T. Forster-Carneiro, The Journal of Supercritical Fluids, 2017, 120, 75-85.

177. S. I. Mussatto, L. M. Carneiro, J. P. Silva, I. C. Roberto and J. A. Teixeira, Carbohydrate polymers, 2011, 83, 368-374.

178. A. Lekar, O. Filonova, S. Borisenko, E. Maksimenko, E. Vetrova, N. Borisenko and V. Minkin, Russian Journal of Physical Chemistry B, 2015, 9, 1043-1047.

179. L. Yang, P. Havard, K. Corscadden, C. C. Xu and X. Wang, Bioresource technology, 2017, 237, 108-121.

180. A. Ronix, O. Pezoti, L. S. Souza, I. P. Souza, K. C. Bedin, P. S. Souza, T. L. Silva, S. A. Melo, A. L. Cazetta and V. C. Almeida, Journal of environmental chemical engineering, 2017, 5, 4841-4849.

181. N. Querejeta, M. V. Gil, F. Rubiera and C. Pevida, Greenhouse Gases: Science and Technology, 2018, 8, 309323.

182. A. Sampaio, G. Dragone, M. Vilanova, J. M. Oliveira, J. A. Teixeira and S. I. Mussatto, LWT-Food Science and Technology, 2013, 54, 557-563.

183. B. Kim, J. Yang, M. Kim and J. W. Lee, Bioresource technology, 2020, 303, 122898.

184. A. De Azevedo, P. Mazzafera, R. Mohamed, S. Melo and T. Kieckbusch, Brazilian Journal of Chemical Engineering, 2008, 25, 543-552.

185. M. J. Cocero and L. Calvo, Journal of the American Oil Chemists' Society, 1996, 73, 1573-1578.

186. J. M. DeSimone and W. Tumas, Green chemistry using liquid and supercritical carbon dioxide, Oxford University Press, New York, 2003.

187. L. Manna, C. A. Bugnone and M. Banchero, The Journal of Supercritical Fluids, 2015, 104, 204-211.

H. M. Barbosa, M. M. de Melo, M. A. Coimbra, C. P. Passos and C. M. Silva, The Journal of Supercritical Fluids, 2014, 85 , 165-172.

189. F. Acevedo, M. Rubilar, E. Scheuermann, B. Cancino, E. Uquiche, M. Garcés, K. Inostroza and C. Shene, Journal of Biobased Materials and Bioenergy, 2013, 7, 420-428.

J. M. Araújo and D. Sandi, Food Chemistry, 2007, 101, 10871094.

191. N. A. Akgün, H. Bulut, I. Kikic and D. Solinas, Chemical Engineering \& Technology, 2014, 37, 1975-1981.

192. M. N. Araújo, A. Q. P. L. Azevedo, F. Hamerski, F. A. P. Voll and M. L. Corazza, Industrial Crops and Products, 2019, 141, 111723.

193. J. P. Coelho, R. M. Filipe, M. P. Robalo, S. Boyadjieva, G. S. Cholakov and R. P. Stateva, The Journal of Supercritical Fluids, 2020, 104825

194. S. S. Georgieva, J. A. Coelho, F. C. Campos, M. P. Robalo and R. P. Stateva, Journal of Chemical Technology \& Metallurgy, 2018, 53.

195. E. Reverchon and F. Senatore, Flavour and Fragrance Journal, 1992, 7, 227-230.

R. G. Bitencourt, F. M. Mello, F. A. Cabral and A. J. Meirelles, The Journal of Supercritical Fluids, 2020, 157, 104689.

197. M. M. de Melo, H. M. Barbosa, C. P. Passos and C. M. Silva, The Journal of Supercritical Fluids, 2014, 86, 150-159. 
198. F. Calixto, J. Fernandes, R. Couto, E. J. Hernández, V. Najdanovic-Visak and P. C. Simões, Green Chemistry, 2011, 13, 1196-1202.

199. K. S. Andrade, R. T. Gonçalvez, M. Maraschin, R. M. Ribeirodo-Valle, J. Martínez and S. R. Ferreira, Talanta, 2012, 88, 544-552.

200. A. De Azevedo, T. Kieckbush, A. K. Tashima, R. Mohamed, P. Mazzafera and S. V. de Melo, The Journal of Supercritical Fluids, 2008, 44, 186-192.

201. S. Machmudah, K. Kitada, M. Sasaki, M. Goto, J. Munemasa and M. Yamagata, Industrial \& Engineering Chemistry Research, 2011, 50, 2227-2235.

202. J. Tello, M. Viguera and L. Calvo, The Journal of Supercritical Fluids, 2011, 59, 53-60.

203. M. V. Cruz, A. Paiva, P. Lisboa, F. Freitas, V. D. Alves, P. Simões, S. Barreiros and M. A. Reis, Bioresource technology, 2014, 157, 360-363.

204. B. Ahangari and J. Sargolzaei, Journal of food processing and preservation, 2013, 37, 1014-1021.

205. H. Ribeiro, J. Marto, S. Raposo, M. Agapito, V. Isaac, B. G. Chiari, P. F. Lisboa, A. Paiva, S. Barreiros and P. Simões, European journal of lipid science and technology, 2013, 115, 330-336.

206. H.-C. Huang, C.-M. Wei, J.-H. Siao, T.-C. Tsai, W.-P. Ko, K.-J. Chang, C.-H. Hii and T.-M. Chang, Evidence-based Complementary and Alternative Medicine, 2016, 2016.

207. R. Muangrat and I. Pongsirikul, CyTA-Journal of Food, 2019, 17, 334-346.

208. P. M. A. de Oliveira, R. H. de Almeida, N. A. de Oliveira, S. Bostyn, C. B. Goncalves and A. L. de Oliveira, The Journal of Supercritical Fluids, 2014, 95, 137-145.

209. J. Menzio, A. Binello, A. Barge and G. Cravotto, Processes, 2020, 8, 1062.

210. P. C. Cheung, Food chemistry, 1999, 65, 399-403.

211. K. Srinivas and J. W. King, Functional food product development, 2010, 39.

212. B. Janissen and T. Huynh, Resources, Conservation and Recycling, 2018, 128, 110-117.

213. R. Campos-Vega, G. Loarca-Pina, H. A. Vergara-Castañeda and B. D. Oomah, Trends in Food Science \& Technology, 2015, 45, 24-36.

214. A. Kovalcik, S. Obruca and I. Marova, Food and Bioproducts Processing, 2018, 110, 104-119.

215. J. McNutt, Journal of industrial and engineering chemistry, 2019, 71, 78-88.

216. S. K. Karmee, Waste Management, 2018, 72, 240-254.

217. A. Zabaniotou and P. Kamaterou, Journal of cleaner production, 2019, 211, 1553-1566.

218. A. Zuorro and R. Lavecchia, Journal of Cleaner Production, 2012, 34, 49-56.

219. P. T. Anastas and R. L. Lankey, Green Chemistry, 2000, 2, 289-295.

220. C.-C. Wang, J.-C. Lee, S.-Y. Luo, S. S. Kulkarni, Y.-W. Huang, C.-C. Lee, K.-L. Chang and S.-C. Hung, Nature, 2007, 446, 896-899.

221. N. T. DUNFORD and F. TEMELLI, Journal of food science, 1997, 62, 155-159.

222. S.-D. Yeo, S.-J. Park, J.-W. Kim and J.-C. Kim, Journal of Chemical \& Engineering Data, 2000, 45, 932-935.

223. E. Tommasi, G. Cravotto, P. Galletti, G. Grillo, M. Mazzotti, G. Sacchetti, C. Samorì, S. Tabasso, M. Tacchini and E.
Tagliavini, ACS Sustainable Chemistry \& Engineering, 2017, 5, 8316-8322.

224. D. L. Sparks, L. A. Estévez and R. Hernandez, Green Chemistry, 2009, 11, 986-993. 